FN- -8390

DE93 007616

\title{
BURIED WASTE INTEGRATED DEMONSTRATION PROGRAM \\ DOE COMPLEX BURIED WASTE \\ CHARACTERIZATION ASSESSMENT
}

\author{
P. S. Kaae \\ G. M. Holter \\ S. M. K. Garrett
}

January 1993

Prepared for

the U.S. Department of Eneirgy

under Contract DE-AC06-76RLO 1830

Pacific Northwest Laboratory

Richl and, Washington

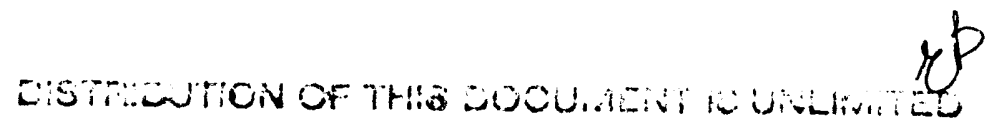




\section{EXECUTIVE SUMMARY}

The work described in this report was conducted by Pacific Northwest Laboratory ${ }^{(a)}$ to provide information to the Buried Waste Integrated Demonstration (BWID) program. The information in this report is intended to provide a complex-wide planning base for the BWID to ensure that BWID activities are appropriately focused to address the range of remediation problems existing across the U.S. Department of Energy (DOE) complex.

This report contains information characterizing the 2.1 million $\mathrm{m}^{3}$ of buried and stored wastes and their associated sites at six major DOE facilities. Approximately $85 \%$ of this waste is low-level waste, with about $12 \%$ TRU or TRU mixed waste; the remaining $3 \%$ is low-level mixed waste. In addition, the report describes soil contamination sites across the complex.

Some of the details that would be useful in further characterizing the buried wastes and contaminated soil sites across the DOE complex are either unavailable or difficult to locate. Several options for accessing this information and/or improving the information that is available are identified in the report.

This document is a companion to Iechnology Needs for Remediation: Hanford and Other DOE Sites, PNL-8328 (Stapp 1993).

(a) Pacific Northwest Laboratory is operated for the U.S. Department of Energy by Battelle Memorial Institute under Contract DE-AC06-76RLO 1830. 


\section{ACKNOWLEDGMENTS}

This report could not have been completed without the expertise of many other people. The authors would like to express their appreciation to Owen Kruger, Westinghouse Hanford Company, for his support on this project. The authors would also like to acknowledge the efforts of our editor, Sheila Bennett; text processors, Cheri Pestes and Rose Urbina; and especially the following Pacific Northwest Laboratory staff members whose research is included in this document:
L. L. Armacost
K. J. Bevertin
C. L. Blackburn ${ }^{(a)}$
M. S. Peffers
J. L. Scott
S. M. Short
D. C. Stapp
D. L. Stiles
J. K. Young

(a) Boeing Computer Services, Richland, Washington. 


\section{CONTENTS}

EXECUTIVE SUMMARY . . . . . . . . . . . . . . . . . . . . i i i

ACKNOWLEDGMENTS . . . . . . . . . . . . . . . . . . . . v v

1.0 INTRODUCTION . . . . . . . . . . . . . . . . . . . . 1.1

2.0 SUMMARY . . . . . . . . . . . . . . . . . . . . . 2.1

2.1 SUMMARY CHARACTERIZATION OF DOE COMPLEX BURIED WASTE

2.2 SUMMARY CHARACTERIZATION OF OTHER SITES WITH SOIL

CONTAMINATION ...................... 2.11

2.3 RECOMMENDATIONS FOR IMPROVEU CHARACTERIZATION TO SUPPORT

THE BURIED WASTE INTEGRATED DEMONSTRATION . . . . . . . 2.12

3.0 DOE COMPLEX BURIED WASTE SITE CHARACTERIZATION $\ldots \ldots \ldots . . . . .3 .1$

3.1 BURIED WASTE CHARACTERISTICS . . . . . . . . . . . 3.1

3.1.1 Overall Complex-Wide Summary . . . . . . . . . 3.1

3.1.2 Site-Specific Information . . . . . . . . . 3.4

3.2 CHARACTERISTICS OF BURIED WASTE STRUCTURES . . . . . . . . 3.30

3.2.1 Overall Complex-Wide Summary . . . . . . . . 3.30

3.2.2 Site-Specific Information . . . . . . . . . 3.31

4.0 OTHER CONTAMINATED SITES FOR WHICH BURIED WASTE TECHNOLOGIES

MAY BE APPLICABLE ...................... 4.1

4.1 OVERALL COMPLEX-WIDE SUMMARY . . . . . . . . . . . 4.2

4.2 SITE-SPECIFIC INFORMATION ............... 4.3

4.2.1 Idaho National Engineering Laboratory _. . . . . 4.4

4.2.2 Hanford . . . . . . . . . . . . . . . 4.4

4.2.3 Savannah River ................ . 4.5

4.2.4 Los Alamos . . . . . . . . . . . . . . . . 4.7

4.2.5 Oak Ridge . . . . . . . . . . . . . . . . . . 4.7 
4.2 .6 Rocky_.flats . . . . . . . . . . . 4.8

4.2 .7 other DOE Sites ................ . . 4.8

5.0 INFORMATION SOURCES AND CONTACTS ............. 5.1

5.1 INFORMATION SOURCES ................... 5.1

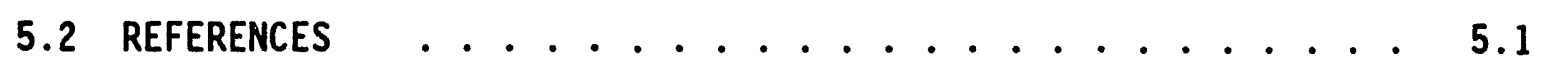

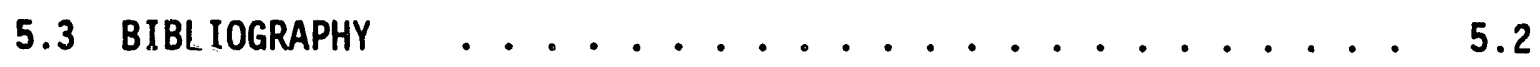

5.4 INFORMATION CONTACTS ...................... 5.4

6.0 GLOSSARY .......................... 6.1

APPENDIX A - INEL BURIED WASTE STRUCTURE CHARACTERIZATION DETAILS . . A.1

APPENDIX B - HANFORD BURIED WASTE STRUCTURE CHARACTERIZATION DETAILS ....................... B.

APPENDIX C - SAVANNAH RIVER BURIED WASTE STRUCTURE CHARACTERIZATION

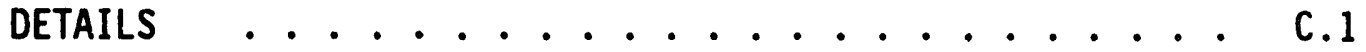

APPENDIX D - LOS ALAMOS BURIED WASTE STRUCTURE CHARACTERIZATION

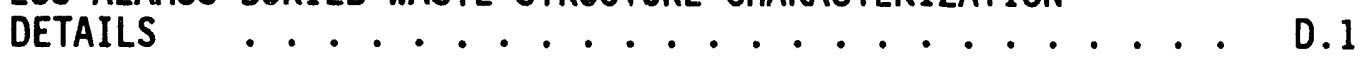

APPENDIX E - OAK RIDGE BURIED WASTE STRUCTURE CHARACTERIZATION

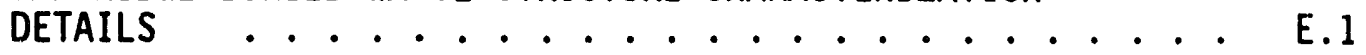

APPENDIX $F$ - ROCKY FLATS BURIED WASTE STRUCTURE CHARACTERIZATION DETAILS ........................... F

APPENDIX $G$ - OTHER BURIED WASTE STRUCTURE CHARACTERIZATION

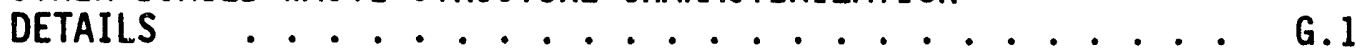




\section{FIGURES}

2.1 Total Waste Volumes by Waste Type ............ 2.3

2.2 Total Waste Volumes by Facility ............ 2.3

2.3 Total TRU Volumes by Facility . . . . . . . . . . 2.4

2.4 Total LLW Volumes by Facility . . . . . . . . . . . . 2.4

2.5 Total LLMW Volumes by Facility ............. 2.5

2.6 Total Volumes by Burial Structure Type . . . . . . . . . 2.6

2.7 Total TRU Volumes by Burial Structure Type . . . . . . . 2.7

2.8 Total LLW Volumes by Burial Structure Type . . . . . . . . . 2.7

2.9 Total LLMW Volumes by Burial Structure Type . . . . . . 2.8

2.10 Total Waste Volumes by Time Period . . . . . . . . . . 2.9

2.11 Total TRU Volumes by Time Period . . . . . . . . . 2.9

2.12 Total LLW Volumes by Time Period ............ . 2.10

2.13 Total Pre-1970 TRU Volumes . . . . . . . . . . 2.10

3.1 Total Waste Volumes by Waste Type at INEL . . . . . . . . 3.9

3.2 Total Waste Volumes by Waste Type at Hanford . . . . . . . . 3.13

3.3 Total Waste Volumes by Waste Type at Savannah River . . . . . . 3.17

3.4 Total Waste Volume by Waste Type at Los Alamos . . . . . . . 3.22

3.5 Total Waste Volumes by Waste Type at Oak Ridge . . . . . . 3.26

3.6 Tutal Waste Volumes by Waste Type at Rocky Flats . . . . . . 3.29 


\section{$\underline{\text { TABLES }}$}

2.1 Total Waste Volumes Throughout the DOE Complex . . . . . . 2.1

2.2 Contaminated Soil Volumes Throughout the DOE Complex for Which

Buried Waste Technologies May Be Applicable . . . . . . . . 2.11

3.1 Volumes of Radioactive Solid Waste by DOE Facility . . . . . . 3.2

3.2 Physical Characteristics of TRU Waste by DOE Facility . . . . 3.3

3.3 Physical Characteristics of LLW and LLMW by DOE Facility . . . . 3.3

3.4 Hazardous Constituents by DOE Facility . . . . . . . . . . 3.4

3.5 Volumes of Radioactive Solid Waste by Structure Type at INEL . . 3.9

3.6 Physical Characteristics of TRU Waste at INEL . . . . . . 3.10

3.7 Physical Characteristics of LLW and LLMW at INEL . . . . . . 3.10

3.8 Hazardous Constituents of LLMW at INEL . . . . . . . . 3.10

3.9 Volumes of Radioactive Solid Waste by Structure Type at Hanford 3.13

3.10 Physical Characteristics of TRU Waste at Hanford . . . . . . 3.14

3.11 Physical Characteristics of LLW and LLMW at Hanford . . . . 3.14

3.12 Hazardous Constituents of LLMW at Hanford . . . . . . . . 3.14

3.13 Volumes of Radioactive Solid Waste by Structure Type at

3.14 Physical Characteristics of TRU Waste at Savannah River . . . 3.18

3.15 Physical Characteristics of LLW and LLMW at Savannah River . . 3.18

3.16 Hazardous Constituents of LLMW at Savannah River . . . . . . 3.18

3.17 Volumes of Radioactive Solid Waste by Structure Type at

3.18 finssical Characteristics of TRU Waste at Los Alamos . . . . 3.23

3.19 Physical Characteristics of LLW and LLMW at Los Alamos . . . . 3.23

3.20 Hazardous Constituents of LLMW at Los Alamos . . . . . . . . 3.23 
3.21 Volumes of Radioactive Solid Waste by Structure Type at Oak Ridge .................. . 3.26

3.22 Physical Characteristics of TRU Waste at Oak Ridge . . . . . 3.27

3.23 Physical Characteristics of LLW and LLMW at Oak Ridge . . . . 3.27

3.24 Hazardous Constituents of LLMW at Oak Ridge . . . . . . . 3.27

3.25 Volumes of Buried Radioactive Solid Waste by Structure Type at Rocky Flats

3.26 Physical Characteristics of TRU Waste at Rocky Flats . . . . 3.30

3.27 Physical Characteristics of LLW and LLMW at Rocky Flats . . . . 3.30

3.28 Hazardous Constituents of LLMW at Rocky Flats . . . . . . . 3.30

4.1 Site Types and BWID Site Categories ........... 4.2

4.2 Other Contaminated Sites Throughout the DOE Complex ..... 4.3

4.3 Waste Types at Other Contaminated Sites Throughout the DOE Complex ..................... 4.4

4.4 Waste Types at Other Contaminated Sites at the INEL Facility ....................... 4.5

4.5 Waste Types at Other Contaminated Sites at the Hanford Facility .................... 4.6

4.6 Waste Types at Other Contaminated Sites at the Savannah River Facility ............... 4.6

4.7 Waste Types at Other Contaminated Sites at Los Alamos . . . . 4.7

4.8 Waste Types at Other Contaminated Sites at Oak Ridge . . . . 4.8

4.9 Waste Types at Other Contaminated Sites at Other DOE

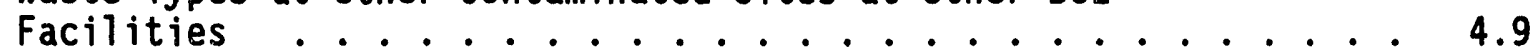

5.1 Information Contacts for BWID Characterization Information . . 5.5 


\subsection{INTRODUCTION}

Over the last five decades, the U.S. Department of Energy (DOE) and its predecessor agencies have operated numerous facilities through the U.S. for a wide range of purposes. Activities at these facilities included nuclear weapons research, development, and production, as well as the peaceful use of nuclear power.

Operating these various facilities has resulted in producing various types of wastes, often including radioactive materials or mixtures of radioactive arid hazardous materials. Some of the solid wastes are buried or stored for future disposal at various DOE sites. Other activities, such as onsite disposal of contaminated wastewater, have resulted in soil contamination at some facilities, with characteristics similar to those of the buried waste sites.

During FY 1990, the DOE Office of Technology Development (OTD) initiated a series of Integrated Demonstrations (IDs) throughout the DOE complex. These IDs are intended to focus technology research, development, demonstration, testing, and evaluation efforts in specific areas of need relative to waste operations and environmental remediation.

Among the IDs being carried out by OTD is the Buried Waste Integrated Demonstration (BWID) being conducted at the Idaho National Engineering Laboratory (INEL). The BWID is aimed at developing and demonstrating technologies applicable to the remediation of sites throughout the DOE complex that contain furisd wastes. These buried wastes include radioactive wastes, hazardous wastes, and mixed radioactive/hazardous wastes; but nonradioactive, nonhazardous wastes are not included in the scope of this effort. The associated buried waste sites include various structures such as trenches, pits, shafts, landfills, caissons, and other site-specific designs.

Many of the technologies being developed to address buried waste siructures could potentially apply to other sites with soil contamination, including above-ground liquid impoundments, below-ground liquid impoundments/ disposal units, and other contaminated soil sites that may have resulted from such things as spills. 
This report is a compilation of information characterizing the buried and stored wasies and their associated structures across the DOE complev. Also included is similar information for other contaminated soil sites for which the same types of remediation technologies may be applicable. The information in this report is intended to provide a complex-wide planning base for the BWID to ensure that BWID activities are appropriately focused to address the range of problems existing within the DOE complex.

Chapter 2.0 of this report summarizes the overall results of the research and provides recommendations for further actions that would improve this assessment. More detailed characterization information on buried waste sites and on other contaminated soil sites for which similar technologies may be applicable is presented in Chapters $3.0^{\circ}$ and 4.0 , respectively. Chapter 5.0 delineates the major information sources and contacts used in developing this report. Chapter 6.0 contains a glossary, to minimize possible confusion over the terms, acronyms, and abbreviations used in the report. Detailed information on buried waste sites and contaminated soil sites at the various DOE installations are included in the appendixes. 


\subsection{SUMMARY}

This chapter provides a brief summary of the overall results of this study, including recommendations for further actions that could be undertaken to improve this assessment.

\subsection{SUMMARY CHARACTERIZATION OF DOE COMPLEX BURIED WASTE SITES}

Through the end of 1991, the DOE complex had about 3.1 million cubic meters of buried radioactive and/or hazardous solid wastes contained in underground and above-ground storage and disposal locations throughout the country.

The total volumes of waste, broken down by appropriate regulatory categories, are shown by major DOE facility in Table 2.1. The reported volumes do not include tank waste volumes or projected volumes from complex-wide decontamination and decommissioning (D\&D) activities. Additional details about the volumes presented in the table are described in subsequent sections of this report.

For this table, and throughout this report, transuranic (TRU) waste is defined as including mixed TRU waste (i.e., TRU waste with contamination by hazardous components), because both types of waste are destined for disposal

IABLE 2.1. Total Waste Volumes Throughout the DOE Complex ${ }^{(a)}$

\begin{tabular}{|c|c|c|c|c|c|}
\hline Facility & $\begin{array}{c}\text { LLW Volume } \\
\left(\mathrm{m}^{3}\right)\end{array}$ & $\begin{array}{c}\text { LLMW Volume } \\
\left(\mathrm{m}^{3}\right)\end{array}$ & $\begin{array}{c}\text { TRU Volyme } \\
\left(\mathrm{m}^{3}\right)\end{array}$ & $\begin{array}{c}\text { Other } \\
\text { Waste } \\
\left(\mathrm{m}^{3}\right) \\
\end{array}$ & $\begin{array}{c}\text { Total } \\
\text { Vol ume } \\
\left(\mathrm{m}^{3}\right)\end{array}$ \\
\hline INEL & 171.500 & 27,000 & 94,600 & & 293,000 \\
\hline Hanford & 581,500 & 10,800 & 116,900 & 120 & 709,300 \\
\hline Savannah River & 616,700 & 9,000 & 8,600 & & 634,200 \\
\hline Los Alamos & 210,200 & 300 & 21.500 & & 232,100 \\
\hline Oak Ridge $(x-10)$ & 205,100 & 1.300 & 7,000 & & 213,400 \\
\hline Rocky Flats & & 8,500 & 900 & & 9,400 \\
\hline Others & 935,000 & 49.900 & 2,100 & & 987,000 \\
\hline DOE Site-Wide Total & 2.720 .000 & 106,800 & 251,600 & 120 & $3.078,500$ \\
\hline
\end{tabular}

(a) Numbers have been rounded. Volumes from Other DOE sites were taken from the Integrated Database (IDB) (DOE 1991). 
in the Waste Isolation Pilot Plant (WIPP) repository. Wastes generated prior to segregation of TRU wastes from other wastes, but suspected of meeting the $100 \mathrm{nCi} / \mathrm{g}$ alpha contamination criteria for classification as TRU, are also included with the TRU.

The numbers reported in Table 2.1 are drawn primarily from the DOE Integrated Database (IDB) (DOE 1991). Additional corroborating information was drawn from documentation obtained from the various site contacts. Where data were not readily available to complete various entries in the table, estimates were made; the bases for these estimates are described in Section 3 and the Appendixes.

As shown in the table, there are about 3.1 million $\mathrm{m}^{3}$ of solid wastes at the various DOE facilities around the country. The information presented in this report focuses on six major DOE sites: Hanford, INEL, Oak Ridge $(X-10)$, Los Alamos, Rocky Flats, and Savannah River. As shown in Figure 2.1, about $85 \%$ of the waste at these six sites is low-level waste (LLW), with about $12 \%$ of TRU or TRU mixed waste. Only about $107,000 \mathrm{~m}^{3}$ of low-level mixed wastes (LLMW), or about 3\% of th vatal, have been buried or stored at the various sites since 1986. As shown in Figure 2.2, the sites with the largest volumes of buried wastes include Hanford (34\%) and Savannah River (30\%).

Basic information about the engineering designs and geologic profiles for the waste burial facilities at the various sites are included in Section 3.2, which also includes overview information on the climatic conditions at the sites. The site characteristics information is important in determining the technologies that can be applied to the buried wastes at the various sites.

Climatic and geologic conditions at the various sites are of two generic types: a dry western site with a significant depth to groundwater, and a humid eastern site with substantial annual rainfall and groundwater levels that are relatively near the surface.

The distribution by DOE facility of the total TRU wastes is shown in Figure 2.3; corresponding information for LLW and LLMW is shown in Figures 2.4 and 2.5 , respectively. 


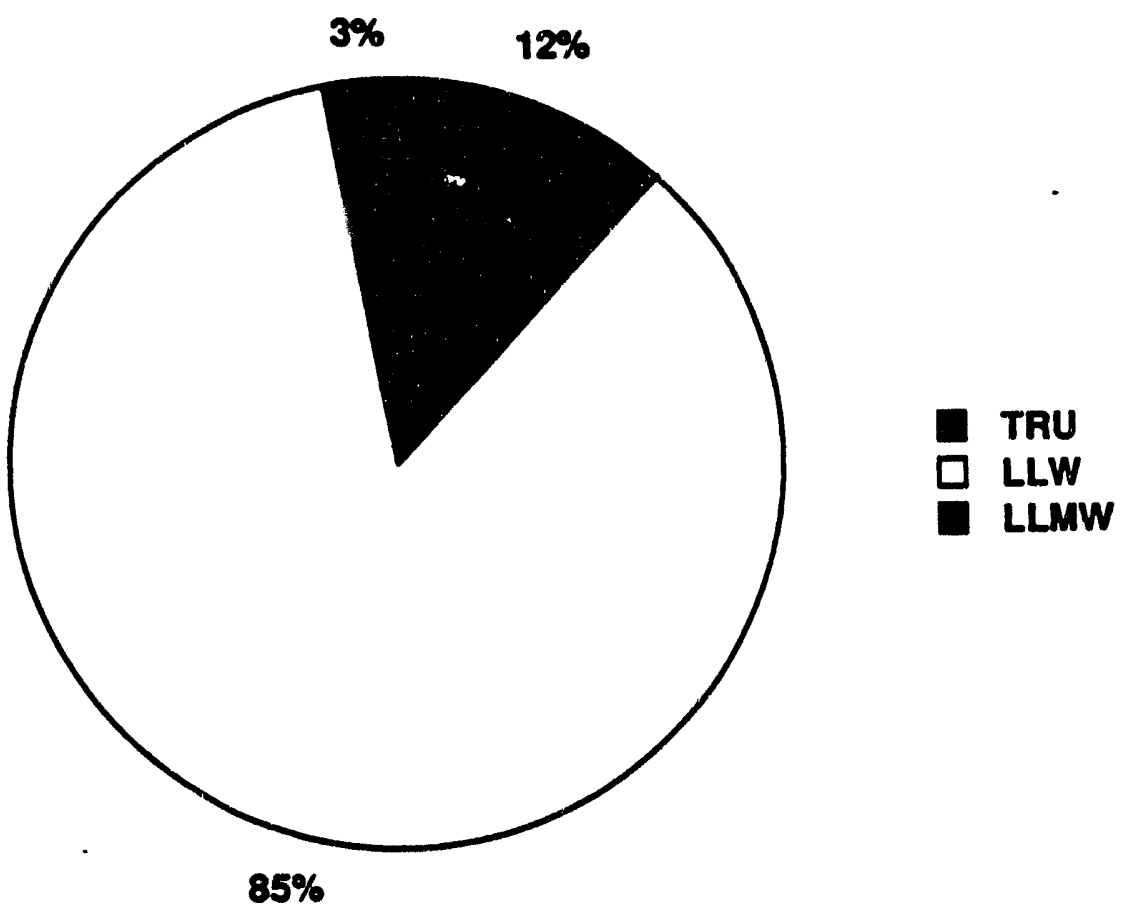

EIGURE 2,1. Total Waste Volumes by Waste Type
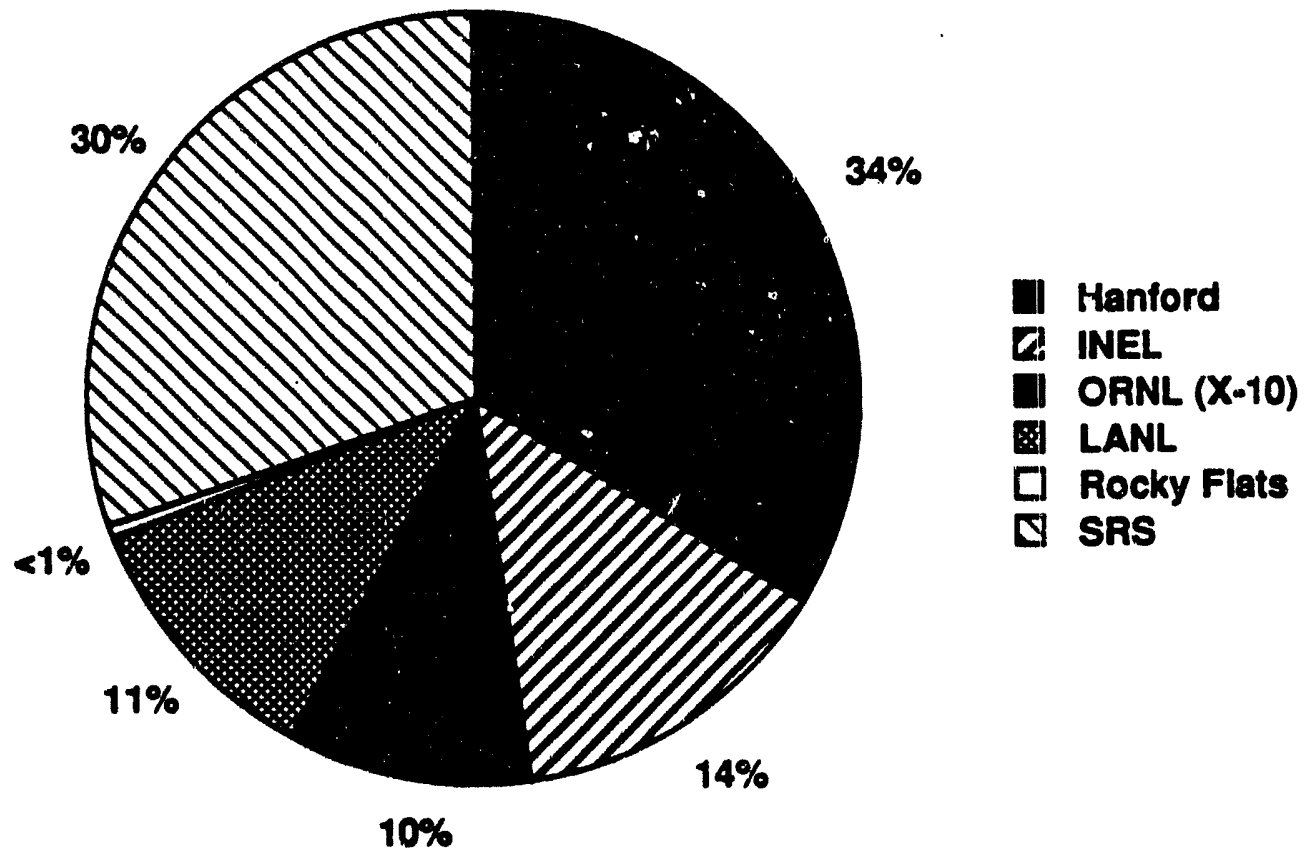

FIGURE 2.2. Total Waste Volumes by Facility 


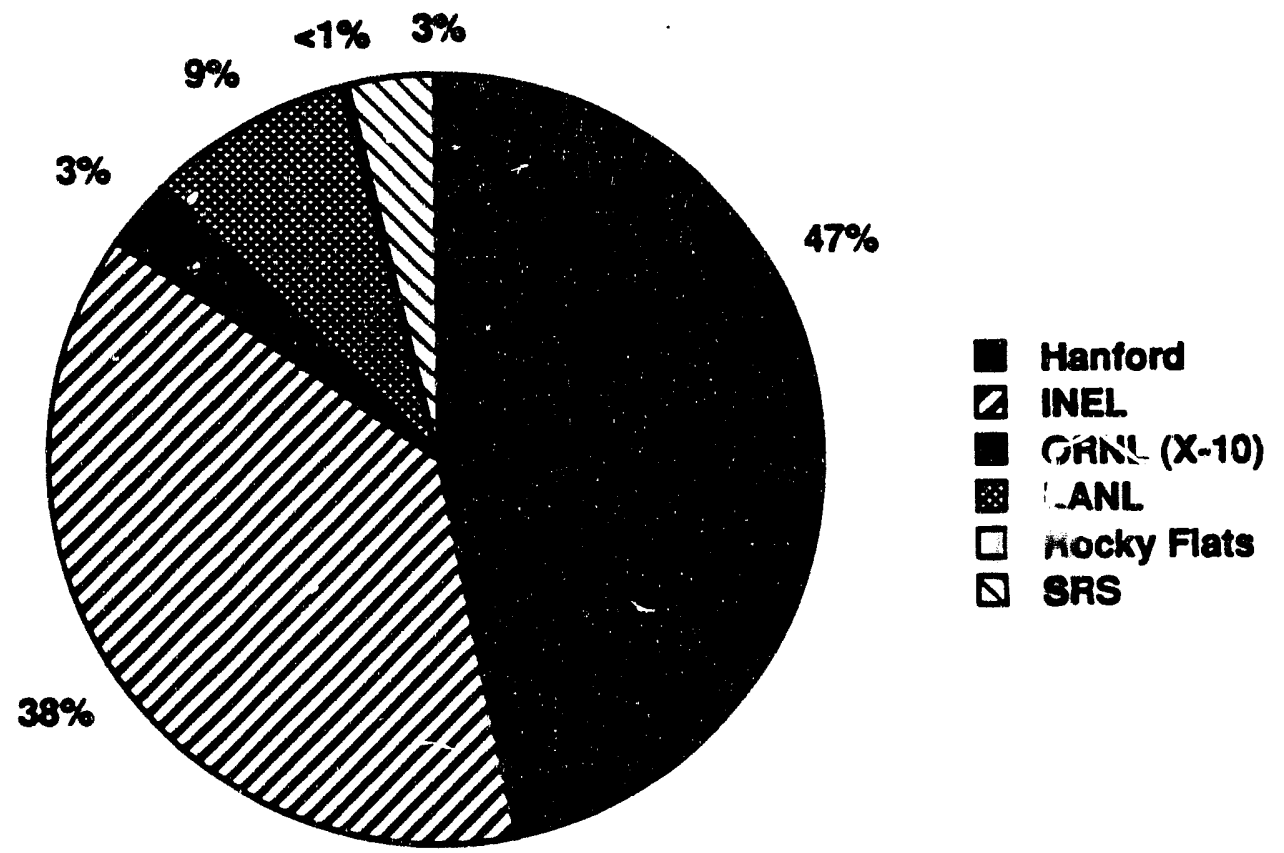

EIGURE 2.3. Total TRU Volumes by Fac lity

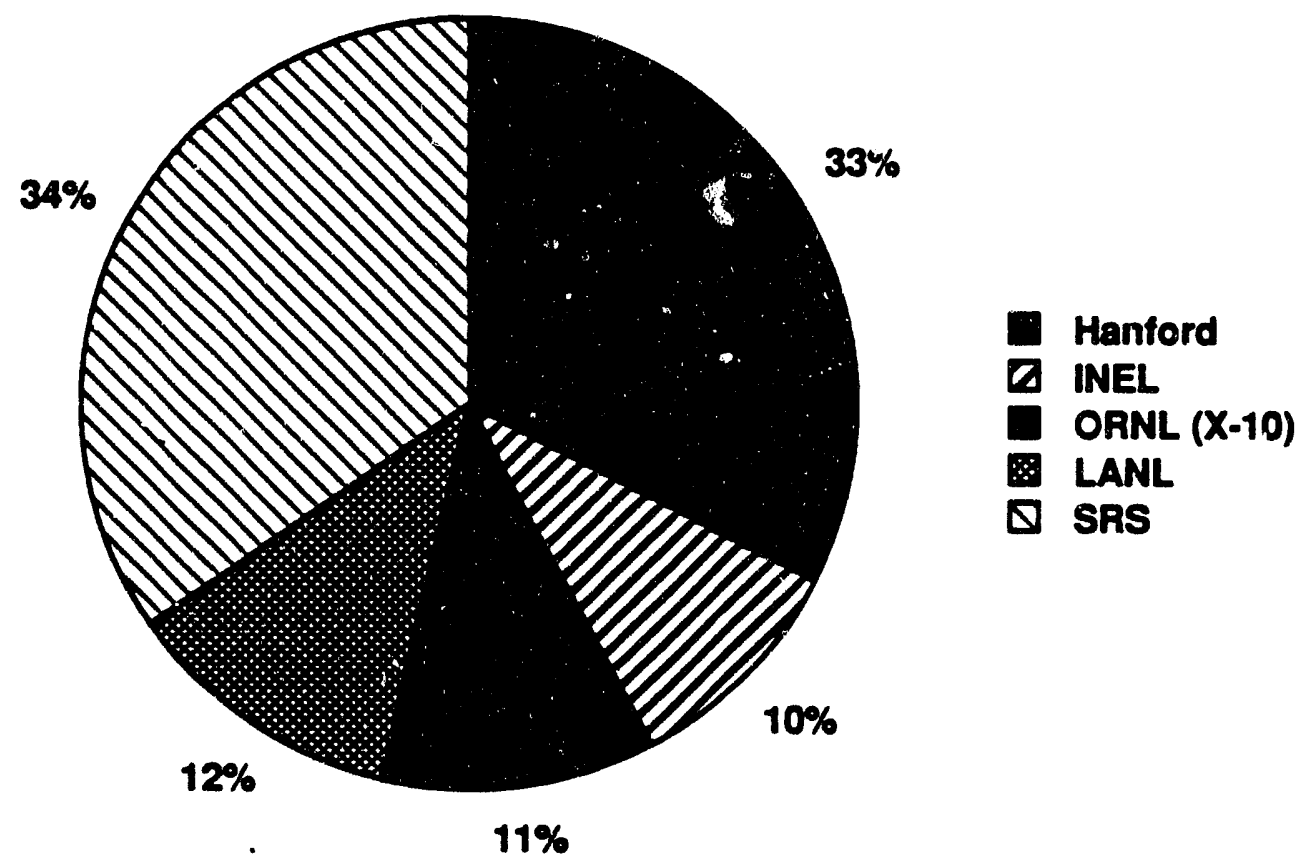

EIGURE 2.4. Total LLW Volumes by Facility 


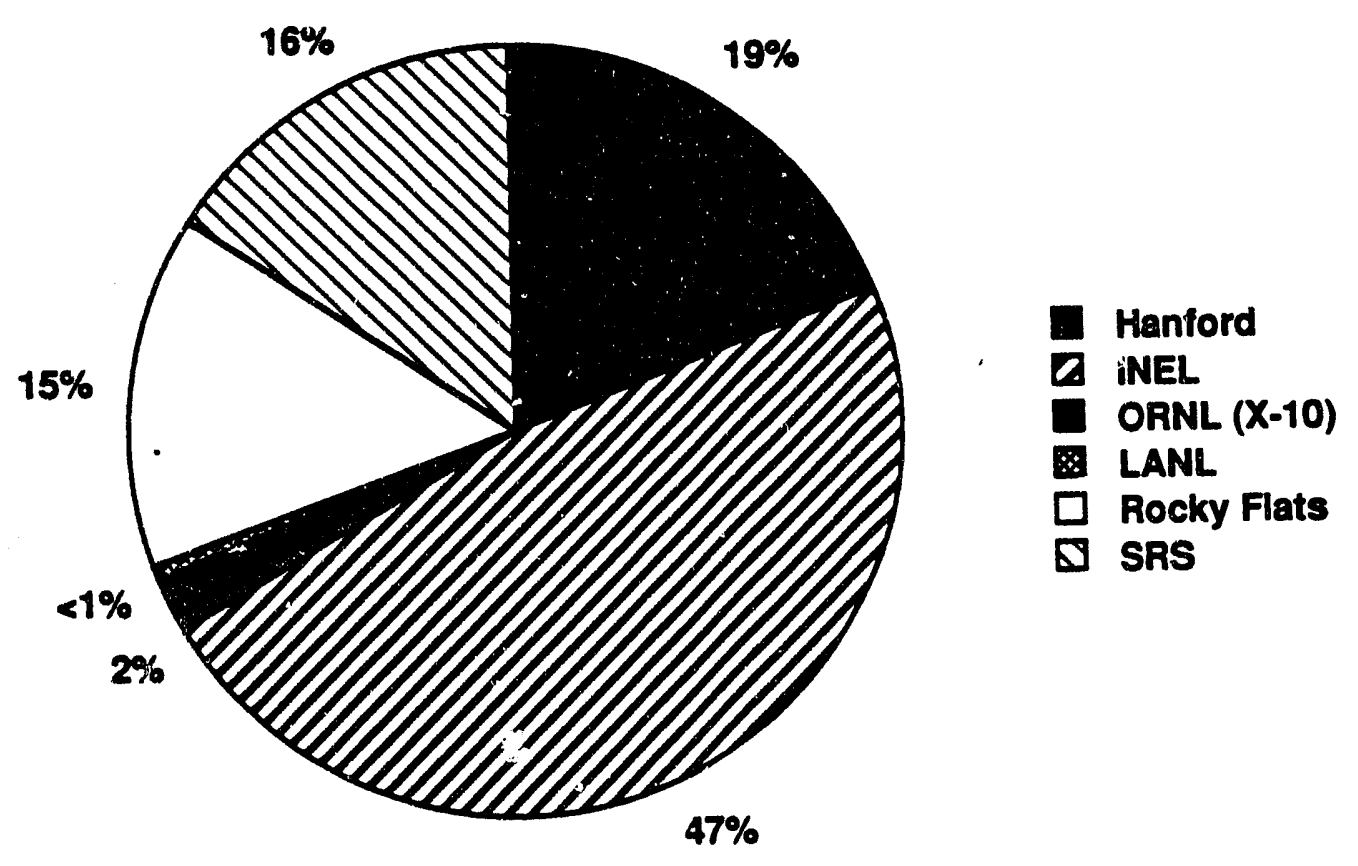

EIGURE 2.5. Total LLM Volumes by Facility

Almost half of the TRU waste is at Hanford. INEL is the second largest TRU site, with the remaining four facilities sharing a total of about $15 \%$ of the TRU waste.

of the LLW, Hanford and Savannah River each have about a third of the total, with the remaining third shared fairly equally by Oak Ridge, Los Alamos, and INEL. The quantity of LLW at Rocky Flats is undetermined, and therefore Rocky Flats was excluded from the figure.

Almost half of the LLMW at the six facilities is contained at INEL. Hanford, Savannah River, and Rocky Flats each have about a sixth of the total. Oak Ridge and Los Alamos report minimal amounts of LLMW.

The wistes at the various facilities are buried or stored in several different types of structures, including trenches, pits, buildings, storage pads; or in other structures specific to each DOE site. These structure types are defined further in Section 3.

The major burial structure used throughout the DOE complex is the trench. As shown in Figure 2.6, of the total waste volumes at the six major 


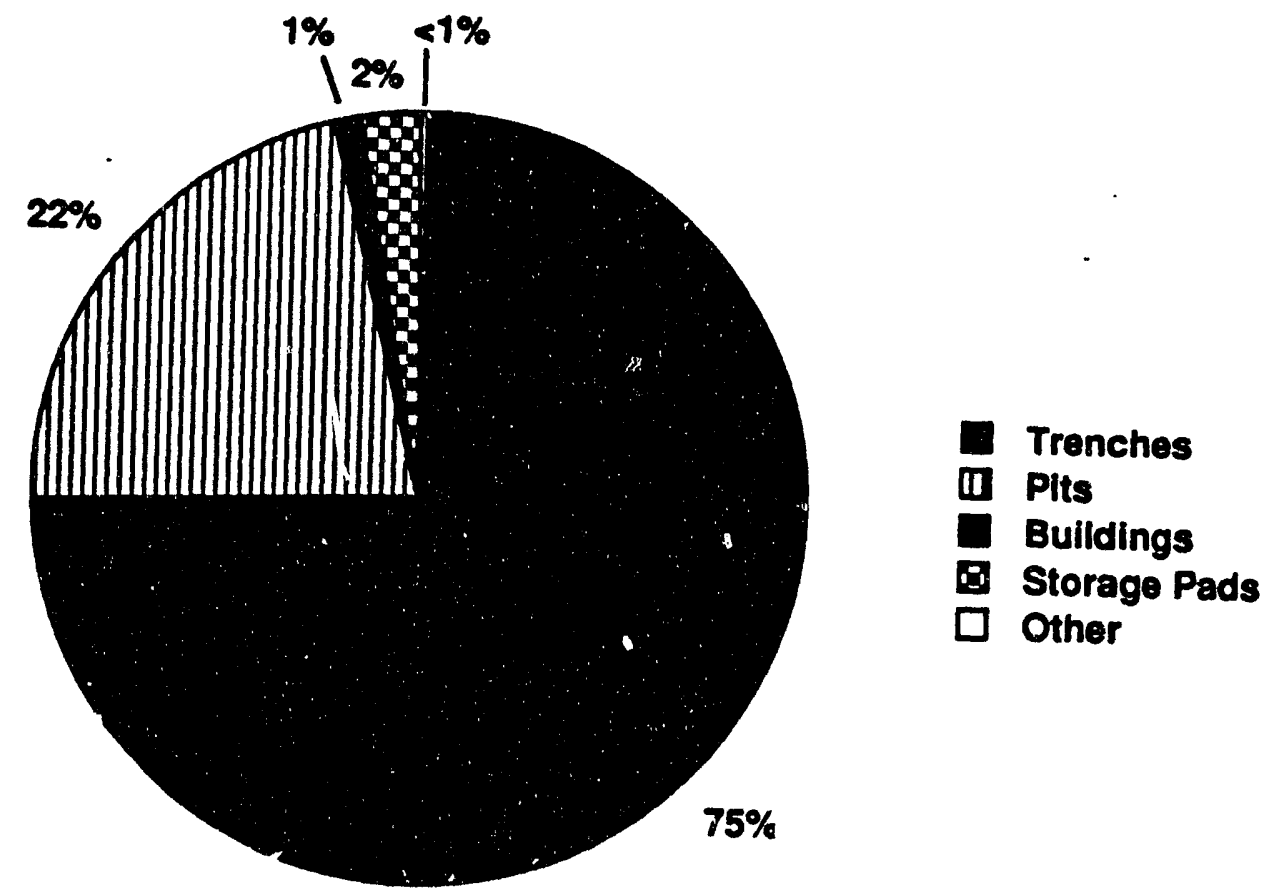

EIGURE2.6. Total Volumes by Burial Structure Type

DOE sites considered in this study, 75\% are buried in trenches. Pits account for about 22\%. Only a small portion of the waste is stored in buildings, on storage pads, or in other structures.

As shown in Figure 2.7, only a little more than half of the TRU waste is in trenches. The bulk of the remaining TRU waste is split about evenly between pits and storage pads.

The distribution of the $L L W$ among the various types of structures, as shown in Figure 2.8 , is very similar to thai for the overall waste volumes (as shown previously in Figure 2.6). This is consistent with the fact that the majority of the wastes are LLW.

Almost half of the LLMW is in pits, as shown in Figure 2.9. Another third of the LLMW is in buildings, with most of the remaining LLMW in
trenches. 


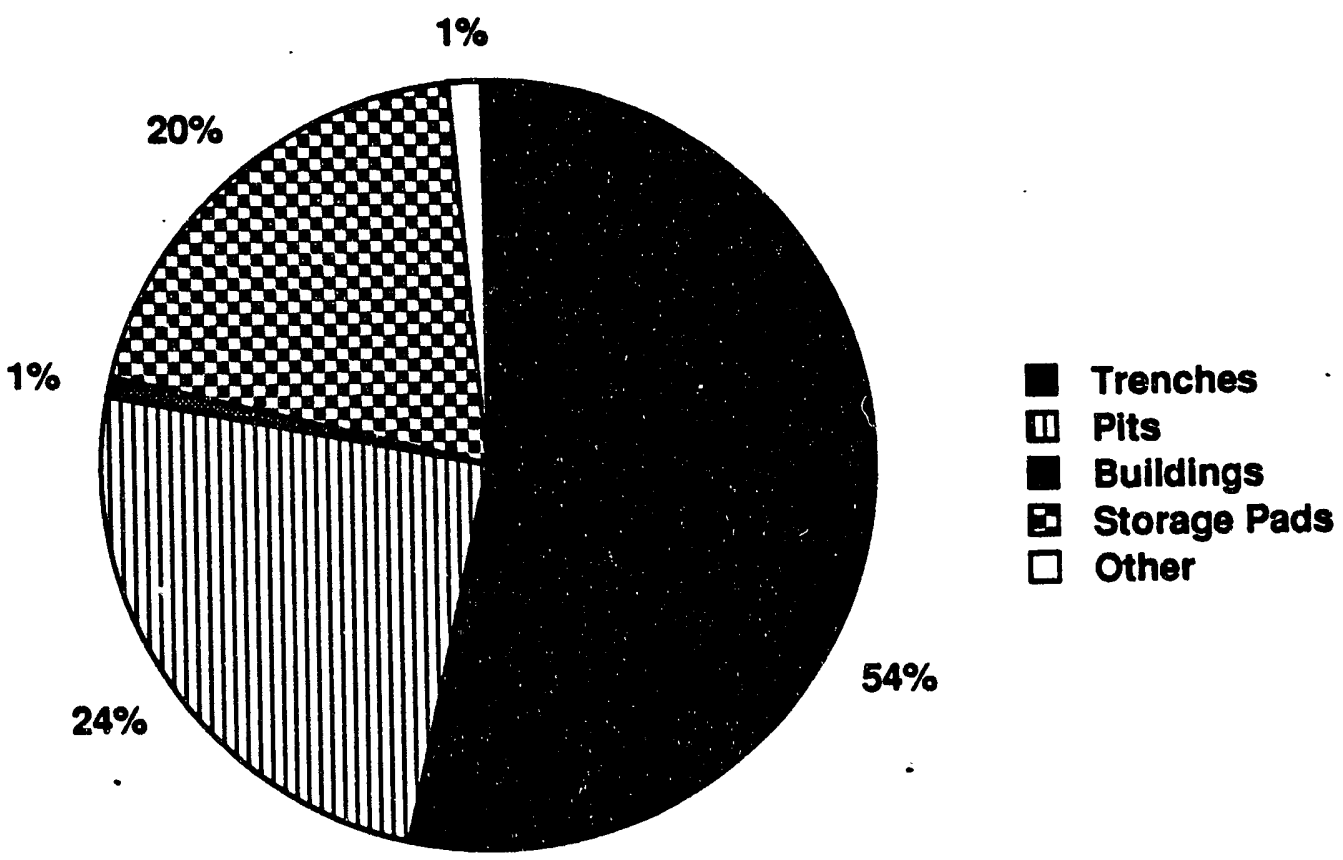

EIGURE 2.7. Total TRU Volumes by Burial Structure Type

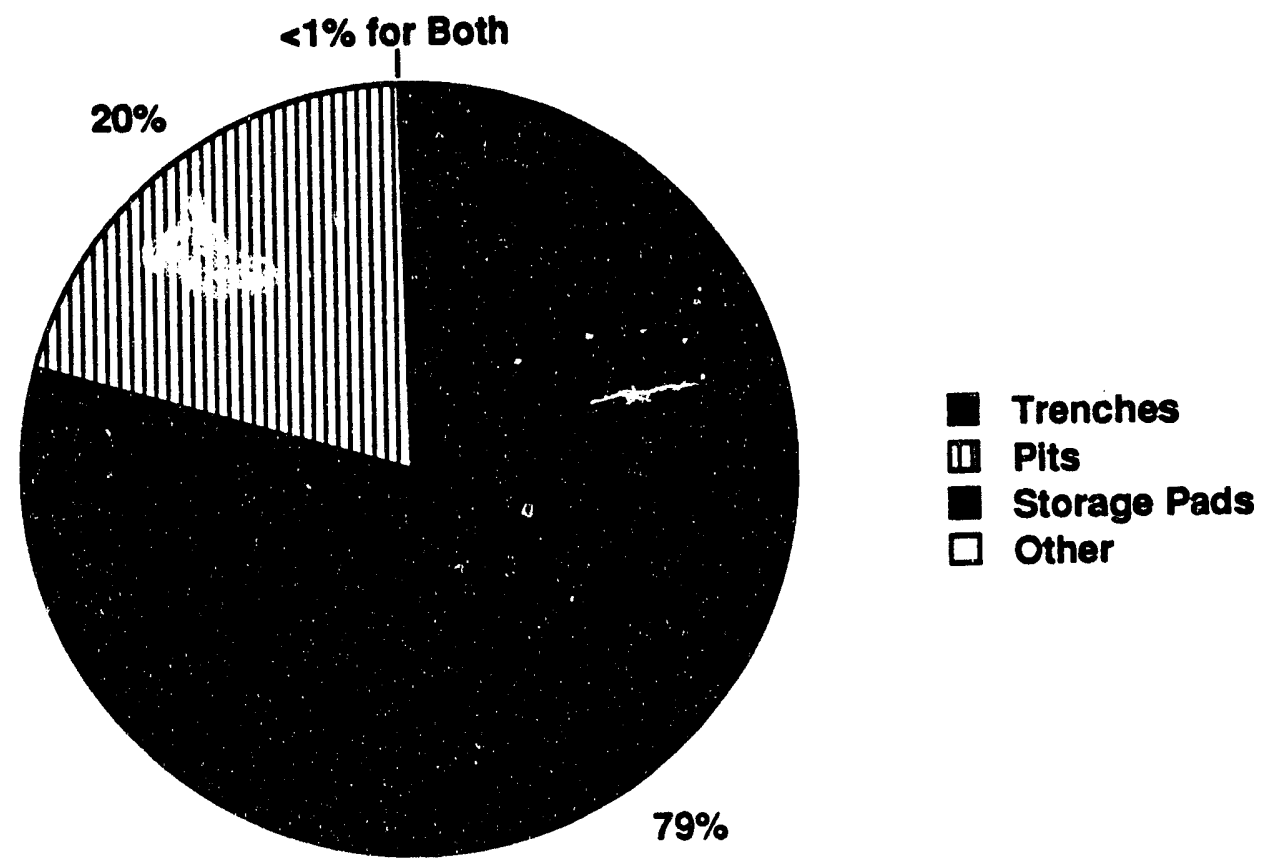

FIGURE 2.8. Total LLW Volumes by Burial Structure Type 


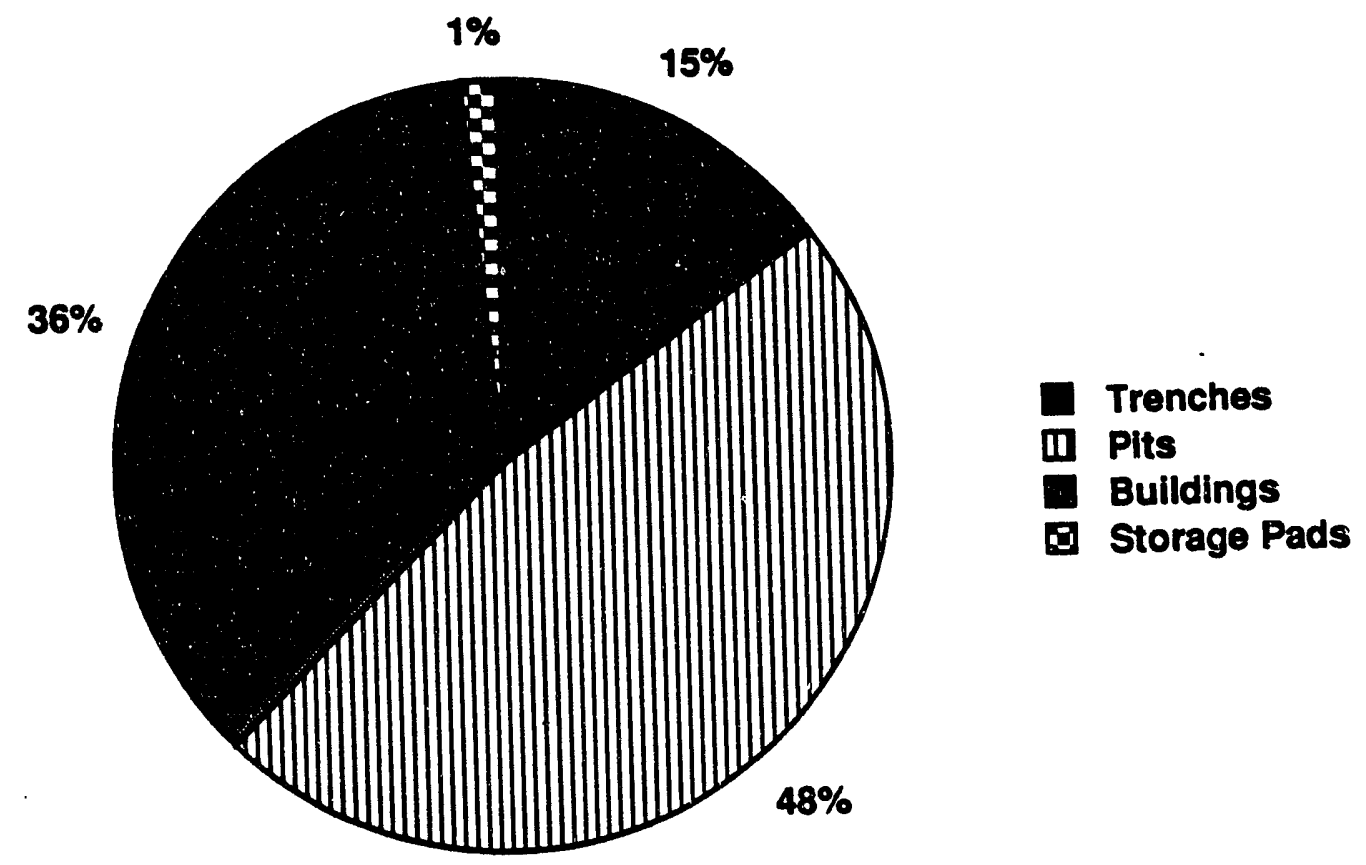

EIGURE 2.9. Tintal LLINW Volumes by Burial Structure Type

The information on waste burials was also analyzed by time period in which the actual burials took place. The resuits of this analysis are shown in Figures 2.10, 2.11, 2.12, and 2.13.

Figure 2.10 shows that almost half of the buried wastes were accumulated prior to 1970, a little over a third of the wastes were accumulated during the period 1970 to 1985 , and less than a fifth of the wastes were accumulated in the period from 1986 through 1990. A similar pattern is indicated for $L L W$, as shown in Figure 2.12 .

A different trend is in evidence for TRU waste, on the other hand, as illustrated in Figure 2.11. Almost three-quarters of the TRU or suspected TRU waste was buried prior to 1970 . Because TRU wastes were not segregated prior to 1970, these results are based on calculations (described later in Section 3 of this report) and are generally consistent with information presented in the IDP.

As shown in Figure 2.13, 60\% of the TRU wastes buried prior to 1970 is buried at Hanford; $32 \%$ is buried at INEL; the remaining $8 \%$ is distributed fairly evenly among Oak Ridge, Los Alamos, and Savannah River. 


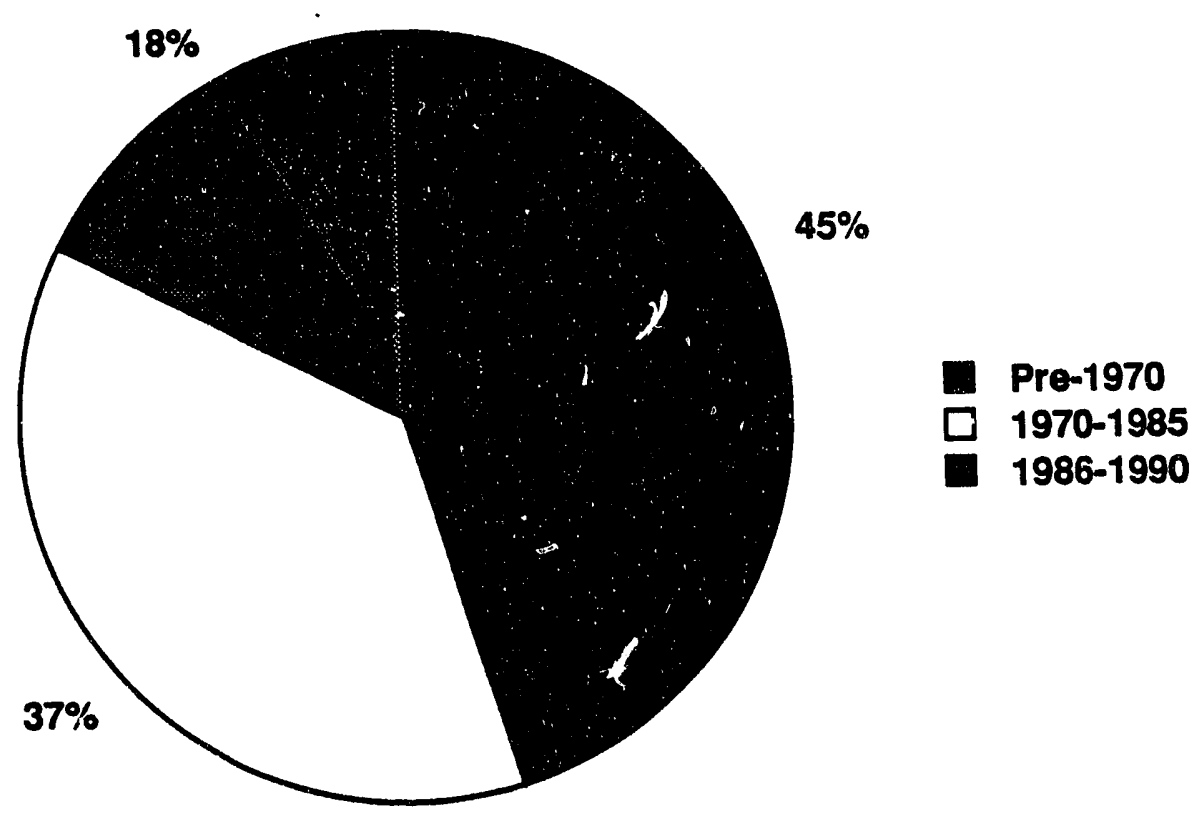

FIGURE 2.10. Total Waste Volumes by Time Period

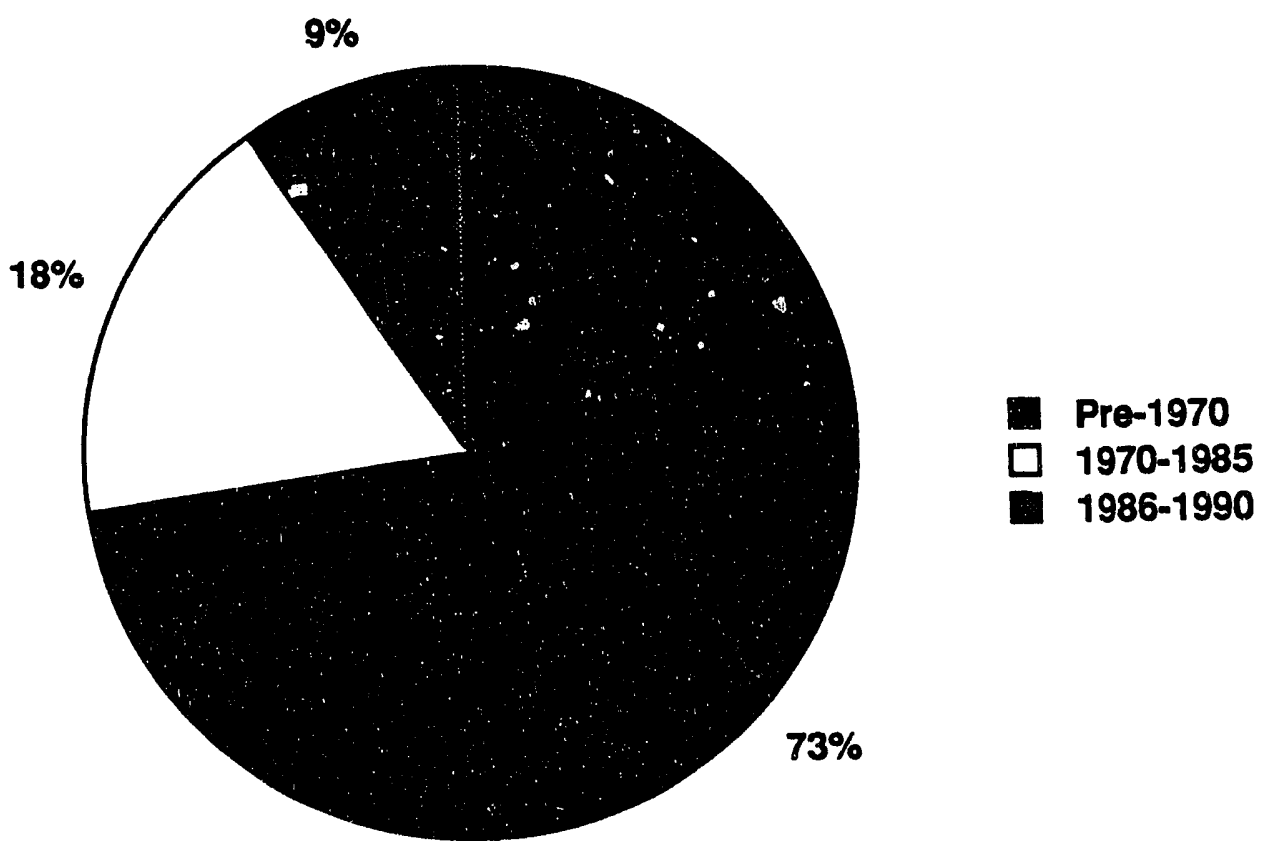

FIGURE 2.11. Total TRU Volumes by Time Period 

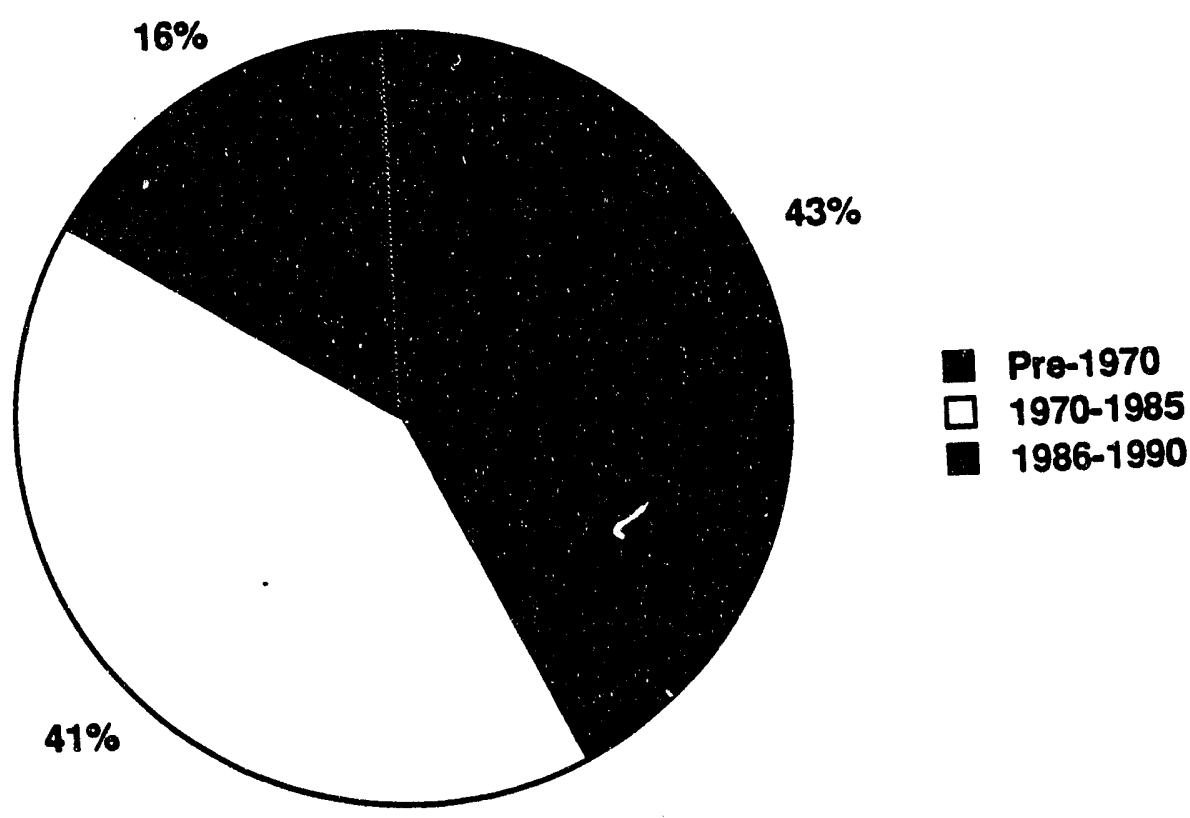

FIGL'RE 2.12. Total LLW Volumes by Time Period

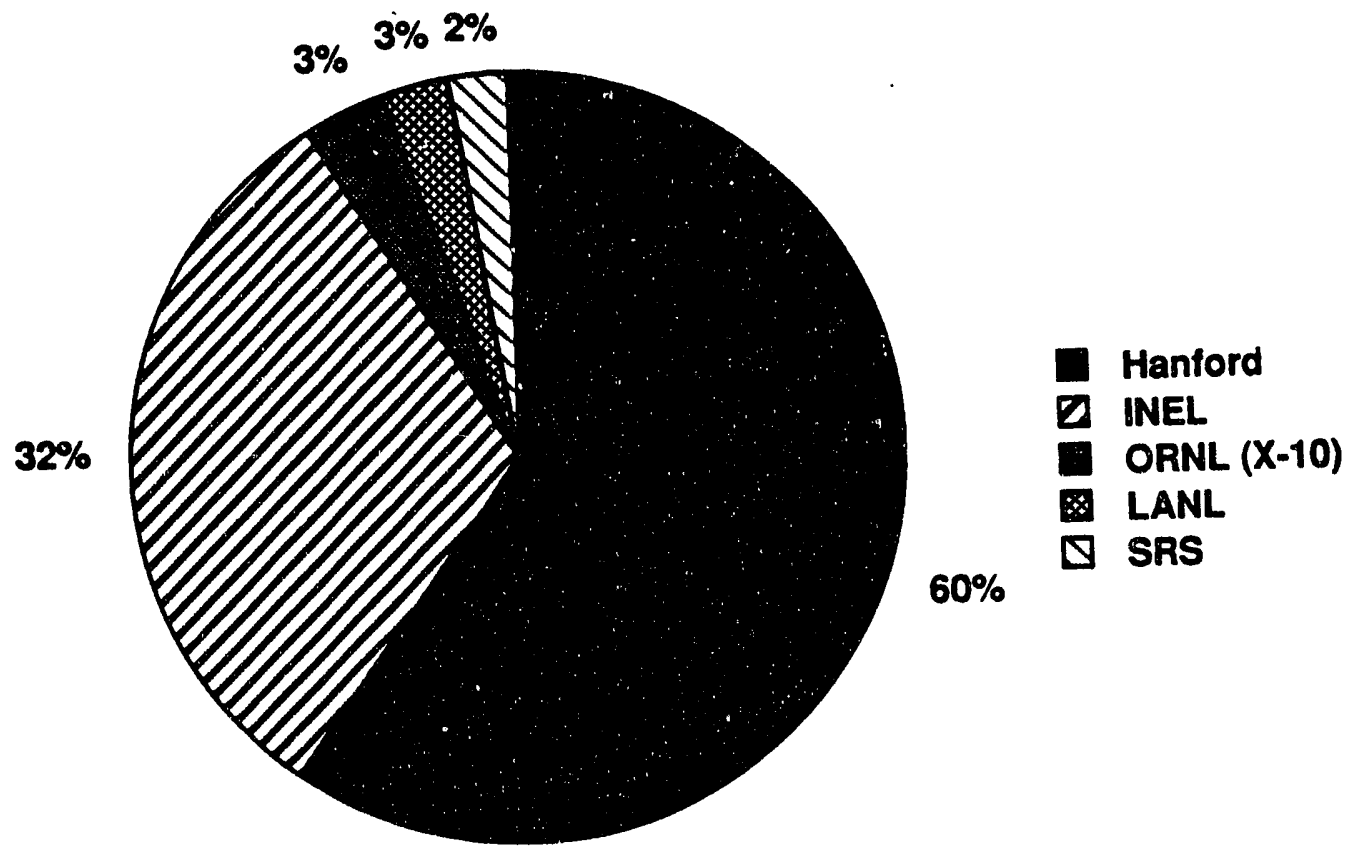

EIGURE 2.13. Total Pre-1970 TRU Volumes 


\subsection{SUMMARY CHARACTERIZATION OF OTHER SITES WITH SOIL COHTAMIIAATION}

DOE has a number of areas on the various sites with soil contamination resulting from past operations, and for which technologies that deal with buried waste may be applicable. These areas are summarized here to indicate the additional volumes of waste materials that may be used as justification for developing buried waste technologies.

A total of 4.7 million cubic meters of contaminated soils is contained in above-ground liquid impoundments, below-ground liquid impoundments/disposal units, and other contaminated soil sites for which data are currently available. The volumes of contaminated soils, broken down by type of contaminated soil sites, is shown by DOE site in Table 2.2. Further details about the types of contamination and the configuration of the sites are included in Section 4.

Note that the volumes of materials included in Table $2.2\left(4,700,000 \mathrm{~m}^{3}\right)$ are about 1.5 times the volumes of buried waste throughout the DOE complex $\left(9,100,000 \mathrm{~m}^{3}\right)$. This indicates that considering these other sites is important in determining the needs and incentives for developing buried waste technologies, because they represent a greater volume than the actual buried waste

TABLE 2.2. Contaminated Soil Volumes Throughout the DOE Complex for Which Buried Waste Technologies May Be Applicable ${ }^{(a)}$

\begin{tabular}{|c|c|c|c|c|}
\hline Facility & $\begin{array}{l}\text { Above-Grourd } \\
\text { Liquid } \\
\text { Impoundments }\left(\mathrm{m}^{3}\right)\end{array}$ & $\begin{array}{l}\text { Below-Ground Liquid } \\
\text { Impoundments/ } \\
\text { Disposal (m })\end{array}$ & $\begin{array}{l}\text { Other Contaminated } \\
\text { Soil Sites }\left(\mathrm{m}^{3}\right)\end{array}$ & $\begin{array}{c}\text { Total Volumes } \\
\left(\mathrm{m}^{3}\right)\end{array}$ \\
\hline INEL & 870,000 & 35 & & 870,000 \\
\hline Hanford & $1,700,000$ & 260,000 & 37,000 & $2,000,000$ \\
\hline Savannah River & 110.000 & & & 110,000 \\
\hline Los Alamos & 35.000 & 280 & $1,500,000$ & $1,540,000$ \\
\hline Oak Ridge & 140,000 & 620 & & 140,000 \\
\hline \multicolumn{5}{|l|}{ Rocky Flats } \\
\hline Other Sites & 22,500 & 180 & 2,100 & 24,000 \\
\hline DOE Complex Total & $2,900,000$ & 260,000 & 1.500 .000 & $4.700,000$ \\
\hline
\end{tabular}


sites. In addition, because data are currently unavailable for the majority of such sites, their importance could be understated by the current volume information.

The sites with the largest volumes of contaminated soils of this type are Hanford and Los Alamos. Key assumptions used in developing the information in Table 2.2 are described in Section 4.

Basic information about the engineering designs and geologic profiles for the various contaminated soil sites are included in Section 4.2. These site characteristics are important in determining the technologies that can be appiied at these sites.

\subsection{RECOMMENDATIONS FOR IMPROVED CHARACIERIZATION TO SUPPORT THE BURIED WASTE INTEGRATED DEMONSTRATION}

The information presented in this report was assembled from various sources, as identified in Section 5. Many of the sources did not have all of the information that was needed for this report, and there is some lack of consistency among the various sources. Additionally, there are much 1 arger databases on waste types and characteristics than were realistically possible to access in this characterization effort.

Furthermore, some of the details that would be useful in further identifying the particular information needs are either unavailable or difficult to locate. For example, to form a complete picture of the needs, it is desirable to correlate site contents (volume, waste classification, physical characteristics, hazardous characteristics, and handling category) with specific site design parameters (such as depth of overburden, depth to groundwater, depth to bedrock, and angles of repose for native sediments, waste materials, and fill). However, such a detailed correlation would be very time-consuming, and the availability of adequate, trustworthy data is in doubt.

Several activities could be conducted to improve the characterization information to support the BWID. These are briefly described below.

- Workshops could tee held with representatives from the various DOE facilities to present the current results and to seek their assistance and knowledge to help refine the information. The workshops 
would be focused on providing improved information in those categories for which it is most needed. Such a set of workshops could be held, and the results incorporated, over a three- to four-month period, at a relatively modest cost to the BWID.

- Most DOE facilities are involved in some form of overall site strategy development and site characterization activity. Generally, there is considerably more waste type and volume information than was readily available for this investigation. Although contacts have been developed during this assessment, it may take involvement by cognizant individuals at each facility, or a visit by members of this characterization effort, to access this larger body of knowledge. This effort is essential to validate and/or refine the data summarized in this report and expand the level of detail to include correlations to D\&D activities, tank waste, and contaminated soil remediation efforts.

- Each DOE facility could designate a representative to supply characterization data to the BWID. This would provide a single point of contact at each facility and would streamline the process of obtaining additional data and verifying data already collected.

- It would also be desirable to identify and coordinate with other DOE-complex data collection efforts that may overlap with the BWID data collectios. requirements. In addition to the IDB, there are many other data compilation efforts under way by various DOE components, both at the national level and at individual sites. Coordinating the various efforts should reduce the number of different requests being handied for similar types of data, while ensuring improved consistency. 


\subsection{DOE COMPLEX BURIED WASTE SITE CHARACTERIZATION}

This section addresses those structures in which solid, radioactive waste (in containers) is buried or stored throughout the DOE compiex. Examples of these structures include trenches, pits, shafts, caissuis, landfills, storage pads, and storage buildings. These burial structures are not used consistently throughout the DOE complex; for example, caissons are unique to the Hanford Site.

\subsection{BURIED WASTE CHARACTERISTICS}

The following subsections auddress the waste volumes, characteristics, and basic assumptions on which the information presented is based.

\subsubsection{Overal1 Complex-Wide Summary}

Approximately 2.1 million cubic meters of radioactive solid wastes have been buried or stored through 1990 at the six sites included in this assessment. A breakdown of this total volume is given in Table 3.1 .

Prior to 1970, TRU and LLW were commonly commingled in the same burial structure at many DOE facilities. During this time, TRU was defired as having a radionuclide content greater than $10 \mathrm{nCi} / \mathrm{g}$. Waste buried during this time is designated in Table 3.1 as pre-1970 waste.

Beginning in 1970, TRU-bearing wastes were packaged and sealed in containers and segregated from LLW in retrievable storage trenches. In 1982 , the lower radionuclide content 1 imit for TRU was revised to $100 \mathrm{nCi} / \mathrm{g}$. Consequently, certain assumptions must be made to quartify the volume of waste that is likely to be LLW and what is suspected to be TRII. These assumptions vary by facility.

The Resource Conservation and Recovery Act (RCRA), enacted in 1986, established the mixed waste classification to account for solid waste that is contaminated with an RCRA regulated (i.e., hazardous) waste. Volumes of buried and/or stored low-level mixed waste (LLMW) and transuranic mixed waste (TRUM) are included in this assessment; no assumptions are made to estimate the volume of buried mixed wastes prior to 1986 . 


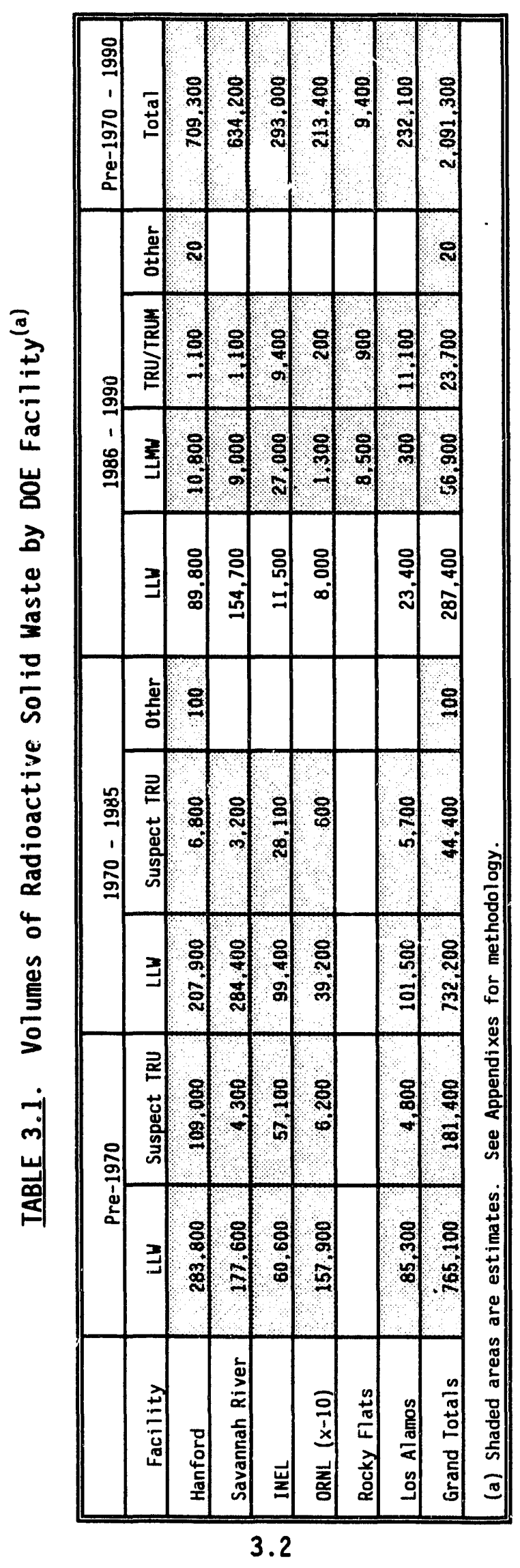


Buried waste can be further delineated by identifying its various physical characteristics. Among the physical attributes included in this assessment for TRU are absorbed liquids or sludges (sludges), combustibles, non-combustibles, particulates, filters, and other physical characteristics. A breakdown of these physical characteristics is shown in Table 3.2. The volumes in this table were derived from the IDB.

Among the physical attributes included in this assessment for $L L W$ and LLMW are biological materials, contaminated equipment, debris, dry solids, sludges, and other physical characteristics. A breakdown of these physical characteristics is shown in Table 3.3. The volumes in this table were derived from the IDB.

TABLE 3.2. Physical Characteristics of TRU Waste by DOE Facility $\left(\mathrm{m}^{3}\right)$

\begin{tabular}{|l|c|c|c|c|c|c|c||}
\hline & Sludges & Combustibles & $\begin{array}{c}\text { Non- } \\
\text { Combustibles }\end{array}$ & $\begin{array}{c}\text { Par- } \\
\text { ticulates }\end{array}$ & Filters & Other & Total \\
\hline INEL & 17,900 & 27,500 & 19,100 & 3,800 & 2,600 & 23,600 & 94,600 \\
\hline Hanford & 1,100 & 50,400 & 56,000 & 3,500 & 1,100 & 4,800 & 116,000 \\
\hline Savannah River & & 6,000 & 2,600 & & & & 8.500 \\
\hline Los Alamos & 2,200 & 2,900 & 5,200 & 4,300 & 500 & 6,500 & 21,600 \\
\hline Oak Ridge (X-10) & 3,000 & 2,400 & 1,500 & 20 & 200 & 50 & 7,100 \\
\hline Rocky Flats & 300 & 100 & 400 & 10 & 10 & 50 & 900 \\
\hline Total & 23,700 & 89,600 & 84,700 & 11,700 & 4,400 & 35,000 & 249,200 \\
\hline
\end{tabular}

TABLE 3.3. Physical Characteristics of LLW and LLMW by DOE Facility $\left(\mathrm{m}^{3}\right)^{(a)}$

\begin{tabular}{|c|c|c|c|c|c|c|c|}
\hline & $\begin{array}{c}\text { Bio- } \\
\text { logical }\end{array}$ & $\begin{array}{c}\text { Contaminated } \\
\text { Equipment }\end{array}$ & Debris & $\begin{array}{l}\text { Dry } \\
\text { Solids } \\
\end{array}$ & $\begin{array}{c}\text { Solidified } \\
\text { Sludges }\end{array}$ & Other & Total \\
\hline INEL & & & 3,600 & & & 194,800 & 198,400 \\
\hline Hanford & 3.200 & 123,700 & 23,000 & 430,600 & 300 & 11,500 & 592.300 \\
\hline Savannah River & & 222.800 & & 402,800 & & & 625,600 \\
\hline Los Alamos & 400 & 53,800 & 12,500 & 143,600 & & 200 & 210.500 \\
\hline Oak Ridge $(x-10)$ & 32,500 & 75,400 & 8,100 & 64,000 & 22.300 & 3,900 & 206,300 \\
\hline Rocky Flats & & & & 8,500 & & & 8,500 \\
\hline Total & 36,100 & 475,700 & 47,200 & $1,049,500$ & 22,600 & 210,400 & $1,841,500$ \\
\hline
\end{tabular}


- Hazardous constituents of the buried waste are also important to quantify for this assessment. However, since mixed wastes were not regulated until 1986, only limited characterization information is available from each of the DOE. facilities. Table 3.4 shows the hazardous constituents that are known to contaminate the wastes buried or retrievably stored since 1986.

\subsubsection{Site-Specific Information}

\subsubsection{Idaho National Engineering Laboratory (INEL)}

There are four radioactive waste disposal or storage areas at the Idaho National Engineering Laboratory (INEL). This report contains brief descriptions of three of those areas, the SL-1 Burial Ground, the Idaho Chemical Processing Plant calcined solid storage facilities, and the Argonne National Laboratory Radioactive Scrap and Waste Facility, and a more detailed account of the Radicactive Waste Management Complex (RWMC), which contains most of the waste. Estimated volumes are for the total buried waste at INEL.

The waste at INEL is classified as routine or non-routine. The routine waste consists of INEL-generated combustibles, such as protective clothing, decontamination materials, wood, and cardboard. Routine waste has been packed in cardboard boxes and dumped into the trenches and pits or compacted in the trenches. Since 1971, routine waste has been compacted into bales and placed in fiberboard boxes with plastic liners before being buried. INEL-generated, routine combustibles constitute the major portion of waste at INEL (90\%).

IABLE 3.4. Hazardous Constituents by DOE Facility

\begin{tabular}{|l|r|r|r|r|r|r|r|}
\hline & Ignitable & Reactive & Corrosive & Toxic & $\begin{array}{c}\text { Listed RCRA } \\
\text { Vastes }\end{array}$ & PCBs & Total \\
\hline INEL & 300 & & 0 & 400 & 23.800 & 2.400 & 27.000 \\
\hline Hanford & 700 & 3.700 & 60 & 4.600 & 1.600 & 30 & 10.800 \\
\hline Savannah River & 0 & & 100 & 300 & 8.600 & & 9.000 \\
\hline Los Alamos & 10 & 0 & 20 & 60 & 200 & & 300 \\
\hline Oak Ridge $(x-10)$ & 50 & & 0 & 60 & 1.200 & & 1.300 \\
\hline Rocky Flats & 0 & & & 40 & 8.400 & 10 & 8.500 \\
\hline Total & 1.100 & 3,700 & 200 & 5.500 & 43.800 & 2.500 & 56.800 \\
\hline
\end{tabular}


The non-routine waste consists of waste with greater than $500 \mathrm{mR} / \mathrm{hr}$ at three feet, has plutonium/thorium source material, or is a liquid or a slurry. Prior to the late 1960s, this waste was buried in $2 \times 2 \times 3 \mathrm{ft}$ boxes or 30-gallon garbage bags. A standard burial method for non-routine waste starting in the late 1960 s consisted of steel boxes with open ends placed in narrow trenches and filled with waste. When the boxes were full, the waste was covered with soil, and the steel box was lifted out of the trench.

Low-level waste, which consists primarily of routine waste, is further categorized as contaminated trash, process waste, contaminated equipment, and activated metals.

Several container types have been used over the years. Cardboard boxes and plastic wrappings were used routinely until about 1974. Containers at INEL have included 30-, 40-, and 55-gallon drums, cardboard boxes, and wooden boxes up to $105 \times 105 \times 214$ in.; no containers were used for larger individual items, which were treated as loose trash. Large amounts of plastic have been used to line containers. Polyethylene sheet plastic and drum liners, polyvinyl chloride sheets and liners, plastic jugs, and other plastic containers of unkriown composition have all been used.

The major means of burying and storing waste at INEL are trenches, pits, storage pads, and soil vault rows. Soil vault rows were mentioned in the Draft Environmental Impact Statement (INEL 1976), but no description was provided. Storage pads are mostly above-ground for TRU wastes; exceptions are the earlier pads where the wastes were stacked, covered with fire-retardant plywood and nylon reinforced polyvinyl, and then covered with two to three feet of soil. The sides were also covered with soil. Storage pads are 3-in.-thick asphalt over a 4-in. gravel base.

The SL-1 Burial Ground was constructed to receive the waste from a 1961 accidental excursion at the Stationary Low Power Test Reactor (SL-1), which produced some highly radioactive contaminated debris. There is one trench, $6 \times 495 \times 10 \mathrm{ft}$ deep; and two pits, one $12 \times 495 \times 10 \mathrm{ft}$ deep and one $20 \times 400$ $x 10 \mathrm{ft}$ deep. One item buried here is the non-decontaminated reactor, which was covered with lead shielding and soil. Most of the dismantled building, contaminated equipment, and decontamination waste were interred directly in 
the SL-1 burial ground. Although no estimate of the total waste buried was found, an estimated $750 \mathrm{~m}^{3}$ of contaminated soil and gravel have been associated with the site.

The Idaho Chemical Processing Plant (ICPP) calcined solid storage facilities consist of underground storage bins for solid calcined products (mixed waste). The facility was designed to hold $2,200 \mathrm{~m}^{3}$ of waste when full; through 1974, 1,220 $\mathrm{m}^{3}$ of waste had been reported stored in stainless steel bins inside reinforced concrete vaults. Most of the later references used for this study concentrate on TRU waste and do not mention the ICPP storage facility.

Argonne National Laboratory (ANL) Radioactive Scrap and Waste Facility is a $388 \times 448 \mathrm{ft}$ storage structure that uses holes with steel liners for storing TRU wastes. The steel liners are fabricated from Schedule 10 pipe and are $12.33 \mathrm{ft}$ long with a 16-in. outside diameter and 1/4-in. thick walls: The liner bottoms are welded closed; and waste is placed in the 1 iner, which is then filled with concrete and sealed closed. Some of the liners may be filled with gravel instead of concrete. The construction allows for easy retrieval of the liners from the holes.

Waste in this facility consists primarily of waste metal from fuel handling and refabrication operations. By 1974, approximately $60 \mathrm{~m}^{3}$ had been received. Approximately 1,080 holes can be accommodated here.

RMMC Waste - A wide variety of wastes have been buried at the RWMC, including Rocky Flats Plant (RFP) process-generated waste such as sludges, evaporation salts, plutonium-contaminated equipment, and fire cleanup waste; INEL waste, which is mostly routine combustibles; and a small amount of waste from other locations. The wastes include nitrate salts, PCB-contaminated oils and sludges, nitric acid absorbed in combustibles, magnesium oxide crucibles, contaminated styrene polymer-based ion exchange resins, refractory material, empty drums, beryllium, copper molds, asbestos, lead, and mercury. Hazardous and radioactive-only contaminated liquids were disposed of freely and in containers. 
LLW and TRU waste were commingled in the pits and trenches until 1970, although, starting in 1957, pits were generally used for RFP TRU and trenches were generally used for INEL LLW.

Pit 3 contains 10 jet engines an: six boxes of intermediate-level waste (ILW). The ILW is packaged in drums and centered in the boxes, which are then filled with cement. Each box weighs from 12,000 to 14,000 pounds (6-7 tons).

Pit 10 contains fire debris from Rocky $\mathrm{Flats}$ that was decontaminated prior to shipment to INEL. Some of the equipment was dismantled, and some plutonium was retrieved. Fire debris containers and equipment were dumped from the side of the pit and covered with soil. Pit 10 also contains a 12,000-gallon cylindrical metal tank contaminated with mixed fission products.

From 1952 to 1963, drums and wooden crates were stacked. From 1963 to 1969, containers were not stacked; stacking was reinstituted in 1969 to save space.

Some early retrieval tests were performed at INEL in the 1970s, and the results were not very encouraging. In 1971, before markers were removed for additional soil coverage, drums were discovered outside the pit markers. Stacked drums buried 12 years were generally in poor condition. However, randomly buried drums that had been in the ground for three to seven years were more difficult to retrieve, and all of those retrieved had been damaged by heavy equipment during leveling and grading operations. One-quarter of the retrieved randomly buried drums were open; a wooden box that had been buried for five years was in poor condition. A later retrieval effort found removable alpha contamination up to one million counts per minute (cpm) and loose alpha contamination of $100,000 \mathrm{cpm}$.

The last retrieval effort, performed from 1976 to 1978, found alpha contamination levels exceeding two million cpm; two-thirds of the retrieved drums were severely breached, and $6 \%$ of the drums were leaking free liquids.

In addition to the potentially high contamination (items emitting up to $12,000 \mathrm{R} / \mathrm{hr}$ have been buried here) and poor condition of containers, three other factors affect retrieval of buried waste at the RWMC. 
- Unknown locations. Although some records exist on waste locations, the records are incomplete, pit markers have been removed and reset over the years making boundaries unsure, and random dumping has allowed items to move before being covered. During retrieval tests in the 1970s, several drums were found outside pit boundaries.

- Reactivity. The debris is mixed in the trenches and pits, making it potentially reactive.

- Basalt Base. RWMC is constructed on a basalt base. The bottom of the pits and trenches lay only two to five feet above the basalt, making retrieval from the pits and trenches more difficult, since equipment must get below the waste. Retrieving contaminated "soil" is extremely difficult, or impossible, if contaminated basalt must be retrieved. The basalt is reportediy contaminated to a maximum depth of 240 feet.

Figure 3.1 shows the makeup of the solid waste buried and stored at INEL. Fifty-nine percent of the total volume is LLW, $32 \%$ is TRU, and $9 \%$ is LLMW stored at the site since 1986. A summary characterization of waste at INEL is provided in Tables 3.5 through 3.8. The volumes shown in Table 3.5 are based upon a qualitative assessment of the best available information found during this study, primarily upon the IDB. Estimates varied among different sources, possibly because of different assumptions on soil contamination. Some sources reported total waste volumes that included contaminated soils. The IDB estimates did not include any contaminated overburden. The assumptions used to generate the estimates shown in the table are given in Appendix A.

Tables 3.6 and 3.7 describe the physical characteristics of the TRU and LLW at INEL. The hazardous constituents of the mixed waste are delineated in Table 3.8 .

\subsubsection{Hanford}

At the Hanford Site, three different areas, the 100, 200, and 300 Areas, contain approximately $709,200 \mathrm{~m}^{3}$ of buried and retrievably stored radioactive solid wastes. Burial practices and usage of each area are slightly different.

100 Areas. Beginning in 1944, land burial was used in the 100 Areas "to dispose of solid, low-level radioactive waste associated with reactor operations" (Miller and Wahlen 1987). Solid wastes were buried in 28 different 

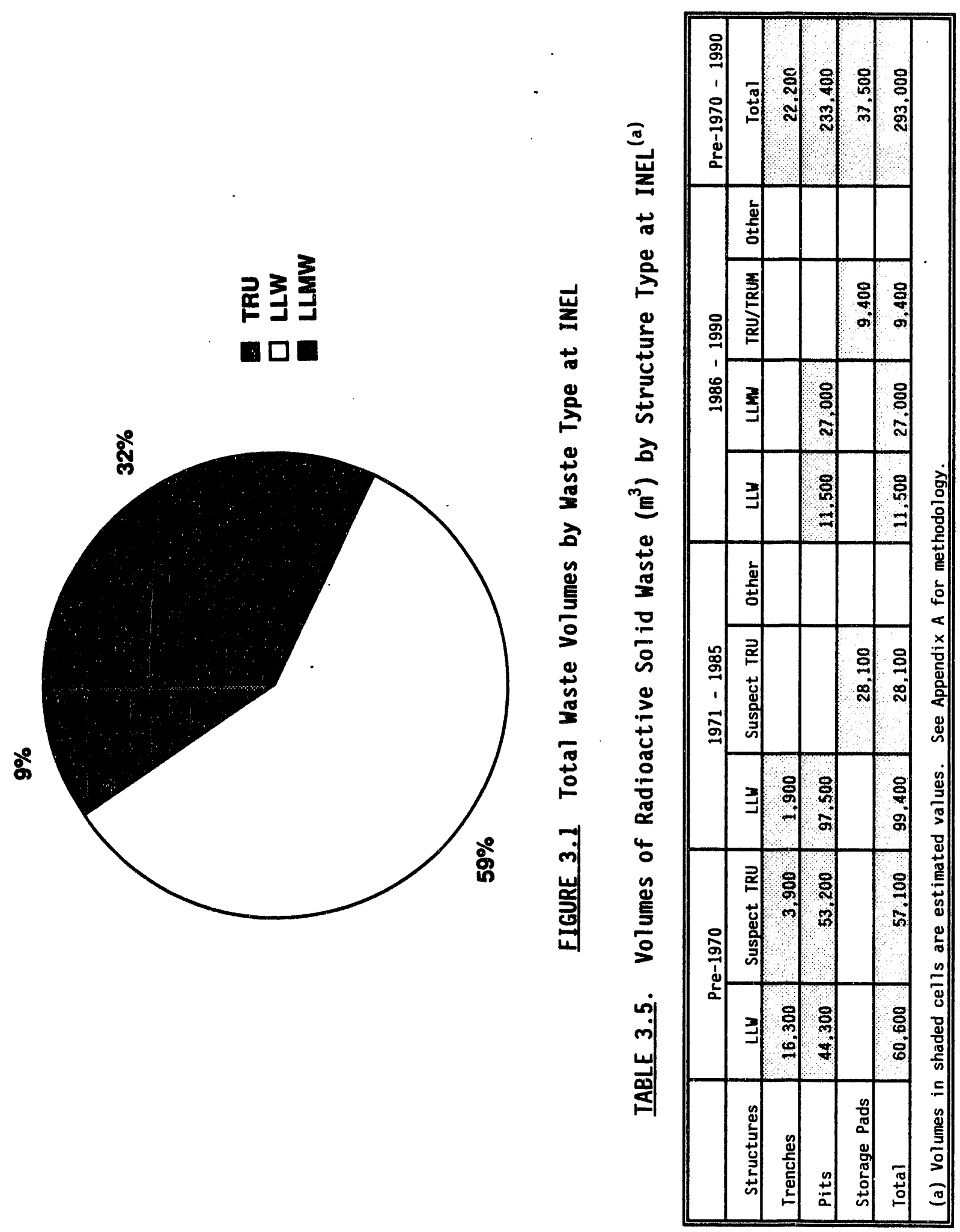
TABLE 3.6. Physical Characteristics of TRU Waste at $\operatorname{INEL}\left(\mathrm{m}^{3}\right)^{(a)}$

\begin{tabular}{|c|c|c|c|c|c|c|c|}
\hline & Sludges & Combustibles & $\begin{array}{c}\text { Non- } \\
\text { Combustibles } \\
\end{array}$ & $\begin{array}{c}\text { Par- } \\
\text { ticulates } \\
\end{array}$ & Filters & Other & Total \\
\hline Trenches & 700 & 1,100 & 800 & 200 & 100 & 1.000 & 3.900 \\
\hline Pits & 10,000 & 15,500 & 10,800 & 2,200 & 1,500 & 13.300 & 53.200 \\
\hline Storage Pads & 7,100 & 10,900 & 7,600 & 1,500 & 1,000 & 9,400 & 37.500 \\
\hline Total & 17.900 & 27,500 & 19,100 & 3.800 & 2.600 & 23,600 & 94,600 \\
\hline
\end{tabular}

IABLE 3.7. Physical Characteristics of LLW and LLMW at INEL $\left(m^{3}\right)^{(a)}$

\begin{tabular}{|c|c|c|c|c|c|c|c|}
\hline & $\begin{array}{c}\text { Bio- } \\
\text { logica? }\end{array}$ & $\begin{array}{c}\text { Contaminated } \\
\text { Equipment }\end{array}$ & Debris & $\begin{array}{l}\text { Dry } \\
\text { Solids } \\
\end{array}$ & $\begin{array}{c}\text { Solidified } \\
\text { Sludges }\end{array}$ & Other & Total \\
\hline Trenches & & & 300 & & & $-17,900$ & 18,200 \\
\hline Pits & & & 3,200 & & & 176,900 & 180,100 \\
\hline \multicolumn{8}{|l|}{ Storage Pads } \\
\hline Total & & & 3,600 & & & 194,800 & 198,400 \\
\hline
\end{tabular}

IABLE 3.8. Hazardous Constituents of LLMW at INEL $\left(\mathrm{m}^{3}\right)^{(\mathrm{a})}$

\begin{tabular}{|l|c|c|c|c|c|c|c|}
\hline & Ignitable & Reactive & Corrosive & Toxic & $\begin{array}{c}\text { Listed RCRA } \\
\text { Wastes }\end{array}$ & PCBs & Total \\
\hline Trenches & & & & & & & \\
\hline Pits & 300 & & 0 & 400 & 23,800 & 2,400 & 27,000 \\
\hline Storage Pads & & & & & & & \\
\hline Total & 300 & & 0 & 400 & 23,800 & 2,400 & 27,000 \\
\hline (a) Volumes in shaded cells are estimated values. See Appendix A for methodology. \\
\hline
\end{tabular}

locations called burial grounds. The majority of the waste generated from reactor operations was placed in seven burial grounds, one for the KE and KW reactors and one for each of the other six reactors at the 100 Areas.

Combustible and noncombustible materials were not segregated until 1954. After 1955, combustibles were burned in trenches; this practice was stopped 
after 1966. Disposal of solid waste in the 100 Areas was discontinued sometime between 1966 and 1973, when centralization of the burial grounds at the 200 Areas began.

Most of the waste buried in the 100 Areas is metal, none of which was specially packaged or treated prior to disposal.

200 Areas. Radioactive waste has also been buried in the 200 Areas since 1944; these areas continue to be active burial sites for solid waste generated at Hanford and offsite facilities. The waste has been generated from reactor operations, chemical processing and separations, research and development (R\&D) activities, and other DOE programs. Waste contamination includes fission products, induced activation products, and TRU isotopes.

Between 1944 and 1970, LLW and TRU waste were not segregated prior to burial. However, since 1970, TRU has been segregated and retrievably buried. Prior to 1987, waste contaminated with hazardous constituents (e.g., mixed radioactive waste) was buried; since then, however, mixed waste has been stored above ground in buildings located in the 200 Areas.

Various waste forms have been buried in the 200 Areas. These include ion exchange resins, asbestos, contaminated equipment, laboratory waste, hot cell waste, and miscellaneous wastes such as contaminated paper, rubber, plastic, and glass. Submarine reactor compartments from the U.S. Navy are also buried in the 200 Areas; these are believed to be included in the LLMW volumes reported in this assessment.

The wastes buried in the 200 Areas have been disposed of in a variety of packages including 55-gallon drums; cardboard, wooden, or metal boxes; concrete cases, or plastic wrap.

300 Area. Burial of radioactive waste was started in the 300 Area in 1943. The largest volume of waste was generated from the fuel fabrication operations. Waste also came from the Plutonium Recycle Test Reactor, lifescience activities, R\&D activities, and support facilities. 
Figure 3.2 shows the makeup of the solid waste buried and stored at Hanford. Eighty-two percent of the total volume is LLW, $16 \%$ is TRU, and $2 \%$ is LLMW stored at the site since 1986. A summary characterization of waste at Hanford is provided in Tables 3.9 through 3.12. The volumes shown in Table 3.9 are based upon a qualitative assessment of the best available information found during this study, primarily upon the IDB. The assumptions used to generate the estimates shown in the table are given in Appendix $B$.

Tables 3.10 and 3.11 describe the physical characteristics of the TRU and LLW at Hanford. The hazardous constituents of the mixed waste are delineated in Table 3.12.

\subsubsection{Savannah River Site (SRS)}

There are 40 waste sites at the Savannah River Site that have or might have received LLW or LLMW. The 40 waste sites consist of basins, burning and rubble pits, the Ford Building waste site, the TNX burial ground, and the central radioactive waste burial grounds. This section of the report concentrates on the central radioactive burial grounds, where the major portion of buried radioactive solid waste is located. Mixed waste stored in buildings outside the central radioactive waste burial grounds is not covered in this report.

There is one central radioactive waste burial area with three different burial grounds (sites) within it. Each site has been assigned a building number: 643-G, 643-7G, and 643-28G. Burial practicas and use are slightly different at each site.

Savannah River Site has segregated its LLW for burial. Wastes with less than $300 \mathrm{mR} / \mathrm{hr}$ at 3 in. and less than $10 \mathrm{nCi} / \mathrm{g}$ of TRU contaminants are labeled "low-level waste." Wastes with more than $300 \mathrm{mR} / \mathrm{hr}$ at $3 \mathrm{in}$. and less than 10 $\mathrm{nCi} / \mathrm{g}$ of TRU contaminants are labeled "intermediate-level waste." Wastes with no beta-gamma emitters and with TRU radionuclides less than $10 \mathrm{nCi} / \mathrm{g}$ are labeled "trench alpha waste." The Savannah River labeling of LLW is used in the following paragraphs, except where noted. TRU waste was defined as waste having TRU at greater than $10 \mathrm{nCi} / \mathrm{g}$ until 1986 at Savannah River; reported TRU 


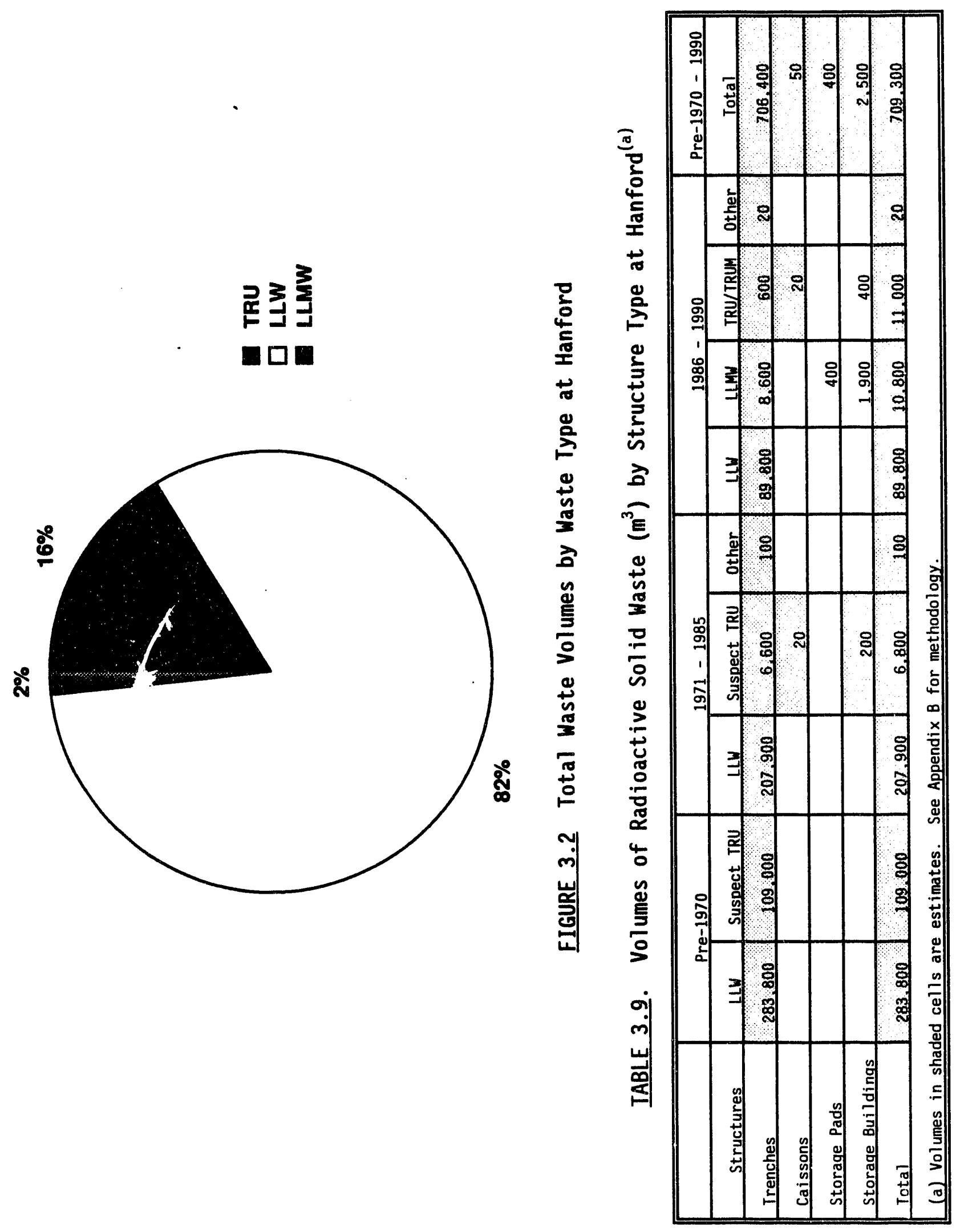


TABLE 3.10. Physical Characteristics of TRU Waste at Hanford $\left(\mathrm{m}^{3}\right)^{(a)}$

\begin{tabular}{|c|c|c|c|c|c|c|c|}
\hline & Sludges & Combustibles & $\begin{array}{c}\text { Non- } \\
\text { Combustibles } \\
\end{array}$ & $\begin{array}{c}\text { Par- } \\
\text { ticulates } \\
\end{array}$ & Filters & Other & Tot $\left.a^{\prime}\right]$ \\
\hline Trenches & 1.100 & 50,100 & 55.700 & 3,500 & 1,100 & 4.800 & 116.2110 \\
\hline Caissons & 0 & 20 & 20 & 0 & 0 & 0 & 50 \\
\hline \multicolumn{8}{|l|}{ Storage Pads } \\
\hline Storage Buildings & 10 & 300 & 300 & 20 & 10 & 30 & 600 \\
\hline Total & 1,100 & 50,400 & $5 \curvearrowleft .000$ & 3,500 & 1.100 & 4,800 & 116,900 \\
\hline
\end{tabular}

TABLE 3.11. Physical Characteristics of LLW and LLMW at Hanford $\left(m^{3}\right)(a)$

\begin{tabular}{|l|r|r|r|r|r|r|r|}
\hline & $\begin{array}{c}\text { Bio- } \\
\text { logical }\end{array}$ & $\begin{array}{c}\text { Contaminated } \\
\text { Equipment }\end{array}$ & Debris & $\begin{array}{c}\text { Ory } \\
\text { Solids }\end{array}$ & $\begin{array}{c}\text { Solidified } \\
\text { Sludges }\end{array}$ & Other & Total \\
\hline Trenches & 3,200 & 123,700 & 23,000 & 429,400 & 300 & 10,400 & 590,000 \\
\hline Caissons & & & & & & & \\
\hline Storage Pads & & & & 200 & & 900 & 1,900 \\
\hline Storage Buildings & & & & 1,000 & & 300 \\
\hline Total & 3,200 & 123,700 & 23,000 & 430,600 & 300 & 11,500 & 592,300 \\
\hline (a) Volumes in shaded areas are estimates. See Appendix B for methodology. & & \\
\hline
\end{tabular}

TABLE 3.12. Hazardous Constituents of LLMW at Hanford $\left(m^{3}\right)^{(a)}$

\begin{tabular}{|l|c|c|c|c|c|c|c|}
\hline & Ignitable & Reactive & Corrosive & Toxic & $\begin{array}{c}\text { Listed RCRA } \\
\text { Wastes }\end{array}$ & PCBs & Total \\
\hline Trenches & 600 & 3.000 & 50 & 3.700 & 1,300 & 30 & 8.600 \\
\hline Caissons & & & & & & & \\
\hline Storage Pads & 20 & 100 & 0 & 200 & 50 & 0 & 400 \\
\hline Storage Buildings & 100 & 600 & 10 & 800 & 300 & 10 & 1,900 \\
\hline Total & 700 & 3.700 & 60 & 4.600 & 1.600 & 30 & 10,800 \\
\hline (a) Volumes in shaded areas are estimates. See Appendix B for methodology. &
\end{tabular}


quantities may include waste now classified as $L L W(<100 \mathrm{nCi} / \mathrm{g})$. Solid radioactive waste has been segregated by activity (e.g., LLW, ILW, trench alpha waste, or TRU waste) since the central radioactive waste site started receiving waste.

643-6. This 76-acre site was used from 1952 through 1972 and is the original central radioactive waste site. Solid wastes were buried in 26 different burial locations, of which 12 contain ILW, eight contain trench alpha waste, and six contain LLW. Until 1965, TRU waste was buried in plastic bags and cardboard boxes in earthen trenches designated specifically for this waste; it is subject to leaching if contacted by water-saturated soil. Waste disposed of in 643-G includes contaminated equipment, reactor hardware and resins, spent lithium-aluminum targets, tritiated oils, tritiated mercury, laboratory operational waste, plutonium process waste from other DOE facilities, and debris from U.S. military plane crashes. Lead, mercury, and cadmium have also been placed in this burial ground.

643-76. This 119-acre site, north of and contiguous to the original 643-G site, has been receiving generated waste since 1969. It is an active LLW burial site, consisting of 25 burial locations (of which 16 make up 64328G) and including trenches, greater confinement disposal boreholes, TRU waste pads, a mixed waste pad, and two storage buildings. Types of waste buried in 643-7G include contaminated equipment, laboratory operational waste, spent lithium-aluminum targets, reactor hardware or resins, and shipments from offsite.

643-28G. This 56-acre site is a closure site within 643-7G defined in 1986 to be closed as a mixed waste management facility. It has received materials defined as hazardous by the Resource Conservation and Recovery Act (RCRA); however, it may contain "pockets" of TRU contamination. The solid wastes were buried in 16 different burial locations, of which 10 have trench alpha waste, three have LLW, and three have ILW. Inventory of 643-28G includes lead, mercury, and cadmium solid waste, various pieces of process equipment, tritiated oil in absorbent, scintillation fluids, filter paper take-up rolls, and PCB-contaminated materials. 
Figure 3.3 shows the makeup of the solid waste buried and stored at Savannah River. Ninety-eight percent of the total volume is LLW, $1 \%$ is TRU, and $1 \%$ is LLMW stored at the site since 1986. A summary characterization of waste at Savannah River is provided in Tables 3.13 through 3.16. The volumes shown in Table 3.13 are based upon a qualitative assessment of the best available information found during this study, primarily upon the IDB. The assumptions used to generate the estimates shown in the table are given in Appendix $C$.

Tables 3.14 and 3.15 describe the physical characteristics of the TRU and LLW at Savannah River. The hazardous constituents of the mixed waste are delineated in Table 3.16.

\subsubsection{Los Alamos Site}

Fifteen different areas have been used for waste disposal at the Los Al amos Site; at least nine may have radioactive solid waste. Some areas have used slightly different burial practices and have been used for different wastes. The nine areas presented in this document are Areas $A, B, C, D, E, F$, $G, T$, and $Y$. Two other areas, $W$ and $X, 1$ ist coolant tanks, which were to be entombed as of 1979, and nuclear reactor vesse1s, which were $p l a n n e d$ for removal to Area $G$. It is assumed in this study that these activities have taken place.

No source was found giving the breakdown of physical characteristics of the waste by volume or waste class. However, radioactive wastes are categorized at Los Alamos as routine or non-routine, and the general physical characteristics of the waste buried in each area are generally known. Most of the waste is routine, consisting of laboratory trash (mostly combustible), equipment, chemicals, oil, animal tissue, chemical treatment sludge, cement paste, hot cell waste, and classified materials. Non-routine waste consists of building debris, large equipment items, and soil or rock removed during site cleanup. Waste may be contaminated with TRU, uranium, fission products, induced activities, or tritium. Wastes contaminated with fission products, tritium, or induced activities make up only $1-3 \%$ of the total waste volume. 


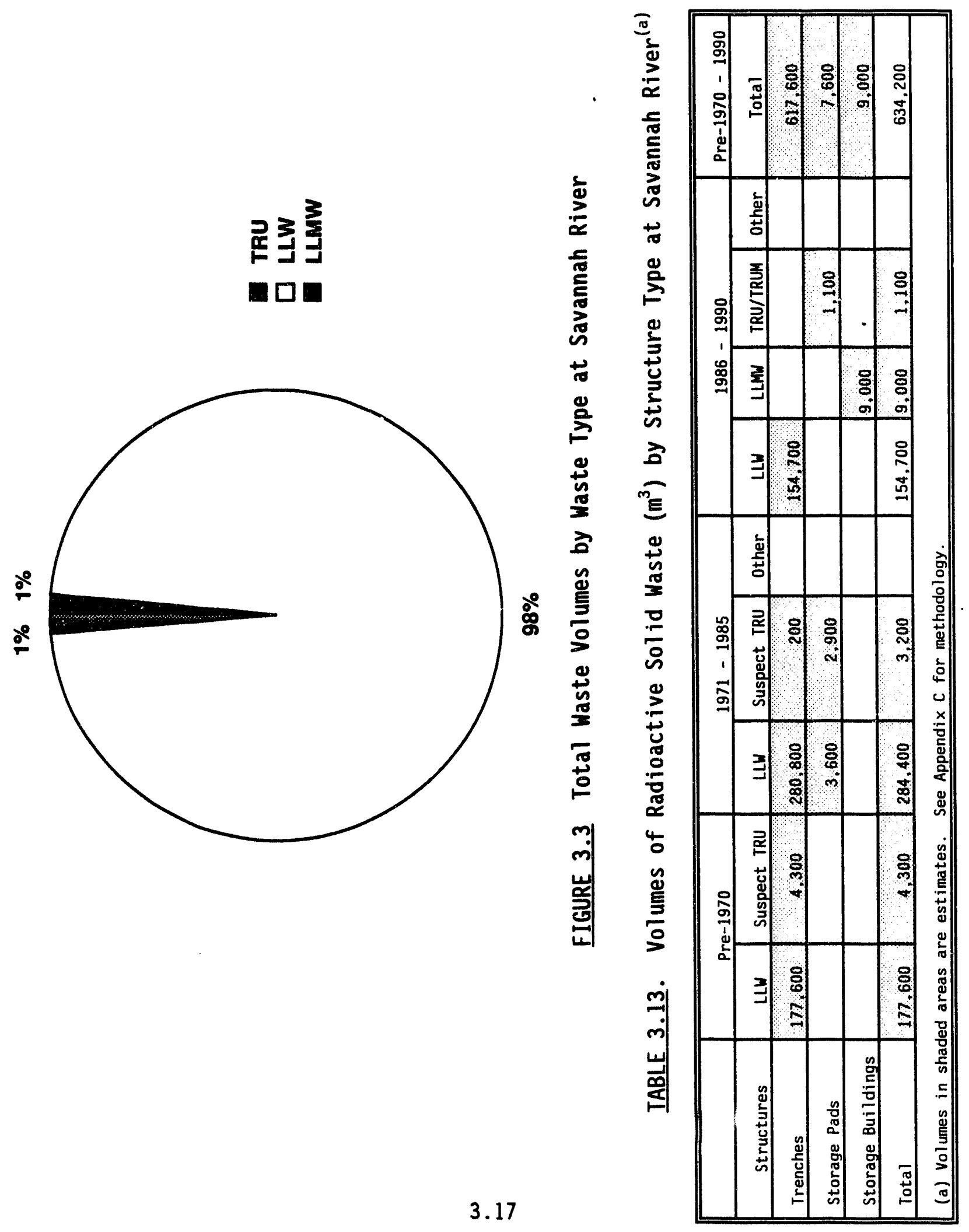


TABLE 3.14. Physical Characteristics of TRU Waste at Savannah River $\left(\mathrm{m}^{3}\right)^{(\mathrm{a})}$

\begin{tabular}{|c|c|c|c|c|c|c|c|}
\hline & Sludges & Combustibles & $\begin{array}{c}\text { Non- } \\
\text { Combustibles } \\
\end{array}$ & $\begin{array}{c}\text { Par- } \\
\text { ticulates }\end{array}$ & Filters & Other & Total \\
\hline Trenches & & 3.200 & 1,400 & & & & 4.500 \\
\hline St - age Pads & & 2,800 & 1,200 & & & & 4.000 \\
\hline \multicolumn{8}{|c|}{ Storage Buildings } \\
\hline Total & & 6,000 & 2,600 & & & & 8,500 \\
\hline
\end{tabular}

TABLE 3.15. Physical Characteristics of LLW and LLMW at Savannah River $\left(m^{3}\right)^{(a)}$

\begin{tabular}{|c|c|c|c|c|c|c|c|}
\hline & $\begin{array}{c}\text { Bio- } \\
\text { logical }\end{array}$ & $\begin{array}{c}\text { Contaminated } \\
\text { Equipment }\end{array}$ & Debris & $\begin{array}{c}\text { Dry } \\
\text { Solids }\end{array}$ & $\begin{array}{l}\text { Solidified } \\
\text { Sludges }\end{array}$ & Other & Total \\
\hline Trenches & & 218,300 & & 394.800 & & . & 613.100 \\
\hline Storage Pads & & 1,300 & & 2,300 & & & 3,600 \\
\hline Storage Buildings & & 3,200 & & 5,800 & & & 9.000 \\
\hline Total & & 222,800 & & 400,800 & & & 625600 \\
\hline
\end{tabular}

TABLE 3.16. Hazardrus Constituents of LLMW at Savannah River $\left(\mathrm{m}^{3}\right)^{(\mathrm{a})}$

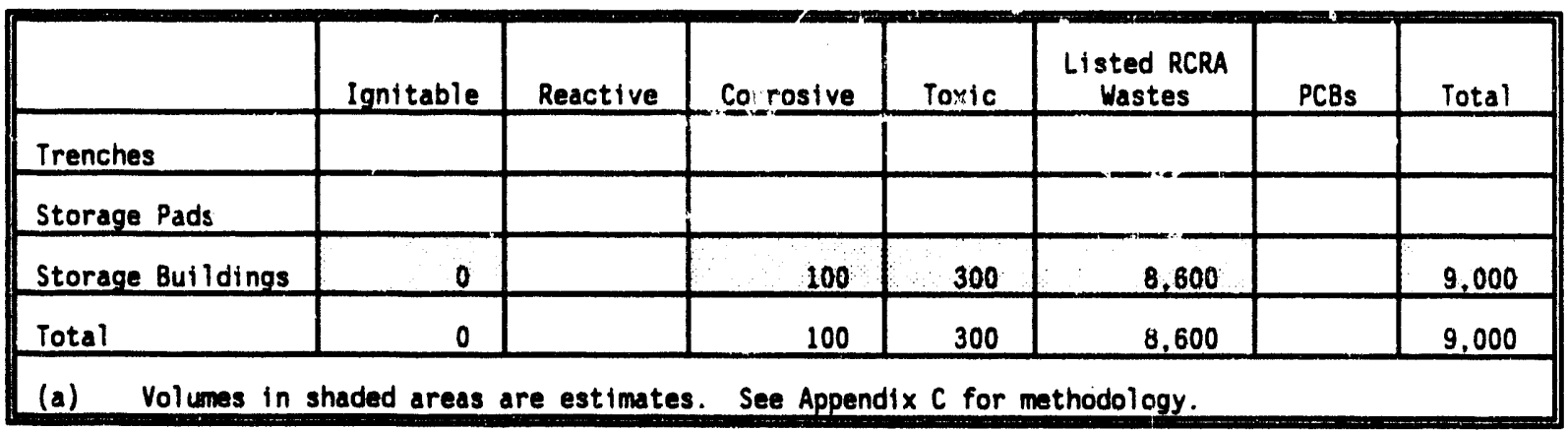

Several container types are used at Los Alamos. Again, r.o information was found on container types by volume of waste or waste class, although some containers are known to be used for only one waste class. Cardboard boxes and/or plastic bags are used for trash. Radioactive oils are absorbed on solids and placed in metal containers. Equipment and building debris are in wooden crates. Tritium-containing wastes are in asphalt-coated, sealed metal 
drums if the concentration is greater than $20 \mathrm{nCi} / \mathrm{m}^{3}$, and completely encased in asphalt if the concentration is greater than $100 \mathrm{Ci} / \mathrm{m}^{3}$. Non-TRU trash is compacted before burial, and the bale is placed directly into the pit.

Retrievable TRU is in 55-gallon drums lined with 90-mil, high-density polyethylene or wooden crates coated with $3.2 \mathrm{~mm}$ of fire-retardant, fiberglassreinforced polyester. TRU sludge (non-retrievable) $<10 \mathrm{nCi} / \mathrm{g}$ is packaged in 5-mil plastic and sealed in 55-gallon drums. High-activity TRU is stored in concrete casks ho?ding two 30-gallon drums in shallow pits. Retrievable cement paste is pumped into vertical welded, galvanized, corrugated metal pipe sections with 1-ft-thick cement caps at each end.

Area A. Area A was used from 1945 to 1946 for disposal of chemical waste and probably contains no TRU waste. Two storage tanks, $12 \mathrm{ft}$ in diameter; $62 \mathrm{ft}, 10 \mathrm{in}$. long; and containing semisolid precipitate in the bottoms, are buried on concrete piers in Area A. This area was used again between 1969 and 1978 for burying demolition debris.

Area B. Area B was used between 1944 and 1948. All types of waste were buried in this area, including chemical materials such as gas cylinders containing $\mathrm{HCl}, \mathrm{H}_{2} \mathrm{~S}$, and $\mathrm{HF}$. Ninety percent of the waste consists of paper, rags, rubber gloves, glassware, and small apparatus placed in cardboard boxes and sealed with masking tape. The rest of the material is metal, e.g., air ducts and large metal apparatus, wrapped in paper. ihere is also some wood, several live batteries, and contaminated or toxic chemicals. At least one truck is buried in this area. Area $B$ also contains a shallow trench for disposal of hazardous material. Material disposed of in the hazardous trench includes old bottles of organics, ethers, and solvents.

Area C. Area C was used from 1948 to 1974 for laboratory waste, building debris, sludge from waste treatment plants, uncontaminated classified materials, and tuballoy chips. Routine trash was buried in cardboard boxes, 5-mil plastic bags, and 55-gallon drums. An experiment with plastic bags and cardboard boxes showed unburied cardboard boxes deteriorated much faster than the 5-mil plastic bags.

There is also a separate chemical pit in Area $C$ that contains "a variety of chemicals; pyrophoric metals; hydrides and powders; sealed vessels 
containing sodium potassium alloy or compressed gases; and equipment not suitable for salvage, public dump, or contaminated dump have been placed in the pit. No high explosives have ever been placed in this pit. Normal uranium powders and hydrides have been disposed of in this pit" (LANL 1987). There are also plutonium contaminated objects and about 200 full or partially full gas cylinders in the chemical pit.

In Area $C$, there are 107 vertical shafts used for wastes with larger quantities of radioactivity. Half the shafts contain TRU wastes. Some of the shaft waste has been placed in sealed "Dural" containers within sealed steel containers.

Area D. Area D was used in 1948 and 1952 for underground testing of explosives containing short-1ived ${ }^{210}$ po (polonium). The waste in Area $D$ is not the typical waste found in radioactive burial structures but consists of two chambers used to test subsurface explosives with ${ }^{210} \mathrm{Po}$. The sizes of the explosion chambers vary by document. A 1977 source reports the chamber in Shaft 2 is a 14-ft-wide, octagonally shaped chamber with a 12-ft ceiling (Rogers 1977). A 1990 source states the chamber in Shaft 1 is $16 \times 18 \times 11 \mathrm{ft}$ high, and the chamber in Shaft 2 is $18 \times 18 \times 16 \mathrm{ft}$ high (LANL 1990). Possible contaminants varied even within the same report. The shafts were shored up with $2 \times 12$ in. timbers. The door to each chamber is constructed of stee 1 filled with wood.

Area E. Area $E$ was used between 1949 and the mid-1960s. Area $E$ contains one chamber, similar to those found in Area $D$, and solid wastes including polonium-beryllium fired targets, a can full of beryllium dust immersed in kerosene, and miscellaneous hot materials.

Area $F$. Area $F$ was active from 1946 to the early 1950s. There is no reliable source of information on waste buried in this area. High explosives have been buried here; some alpha contamination is present; but Area $F$ was mainly used for disposal of toxic compounds. Beta-gamma emitters, equipment, and/or material contaminated with high explosives may also be buried in Area $\mathrm{F}$. 
Area G. Area $G$ became active in 1957 and is still active. This area is the largest burial ground at Los Alamos. There is some TRU waste buried in Area $G$, but most of the waste is considered LLW.

Some of the materials that can be found in Area $G$ include plutonium mixed with sand, TRU sludge mixed with cement, asbestos- and PCB-contaminated wastes, tritium wastes, demolition debris, depleted uranium chips, contaminated oil, "Cancer Suspect Research" waste, building debris, sections of filter plenums, and pieces of heavy equipment such as dump trucks. After 1971, 55-gallon drums (1 ined with 10-mil liners) of sludge and plutoniumcontaminated equipment have been retrievably stored and stacked in the pits.

Routine laboratory waste was buried in cardboard boxes, 5-mil plastic bags, or 55-gallon drums. Retrievable TRU is found in fiberglass-coated crates as well as 55-gallon drums. Wastes with radiolytic gas formation are placed in 30-gallon drums within casks sealed with asphalt materials.

Area T. Area T was used from 1945 to 1967 and is classified as part of the liquid disposal operation. Area $T$ contains treated liquid waste residues mixed with cement in 62 shafts, and retrievable TRU waste mixed with cement and pumped into corrugated metal piping. Fifty-six of the 62 shafts in Area T contain TRU.

Untreated liquid waste from plutonium processing and treated liquid waste containing LLW were deposited in four beds which have since had the bottom material removed and have been filled to ground level.

Area $Y$. Area $Y$ has been in service since 1966. It contains high explosives, contaminated waste, and uranium.

Figure 3.4 shows the makeup of the solid waste buried and stored at Los Alamos. Ninety-one percent of the total volume is LLW, $9 \%$ is TRU, and less than $1 \%$ is LLMW stored at the facility since 1986. A summary characterization of waste at Los Alamos is provided in Tables 3.17 through 3.20. The volumes shown in Table 3.17 are based upon a qualitative assessment of the best available information found during this study, primarily upon the IDB. The assumptions used to generate the estimates shown in the table are given in Appendix D. 


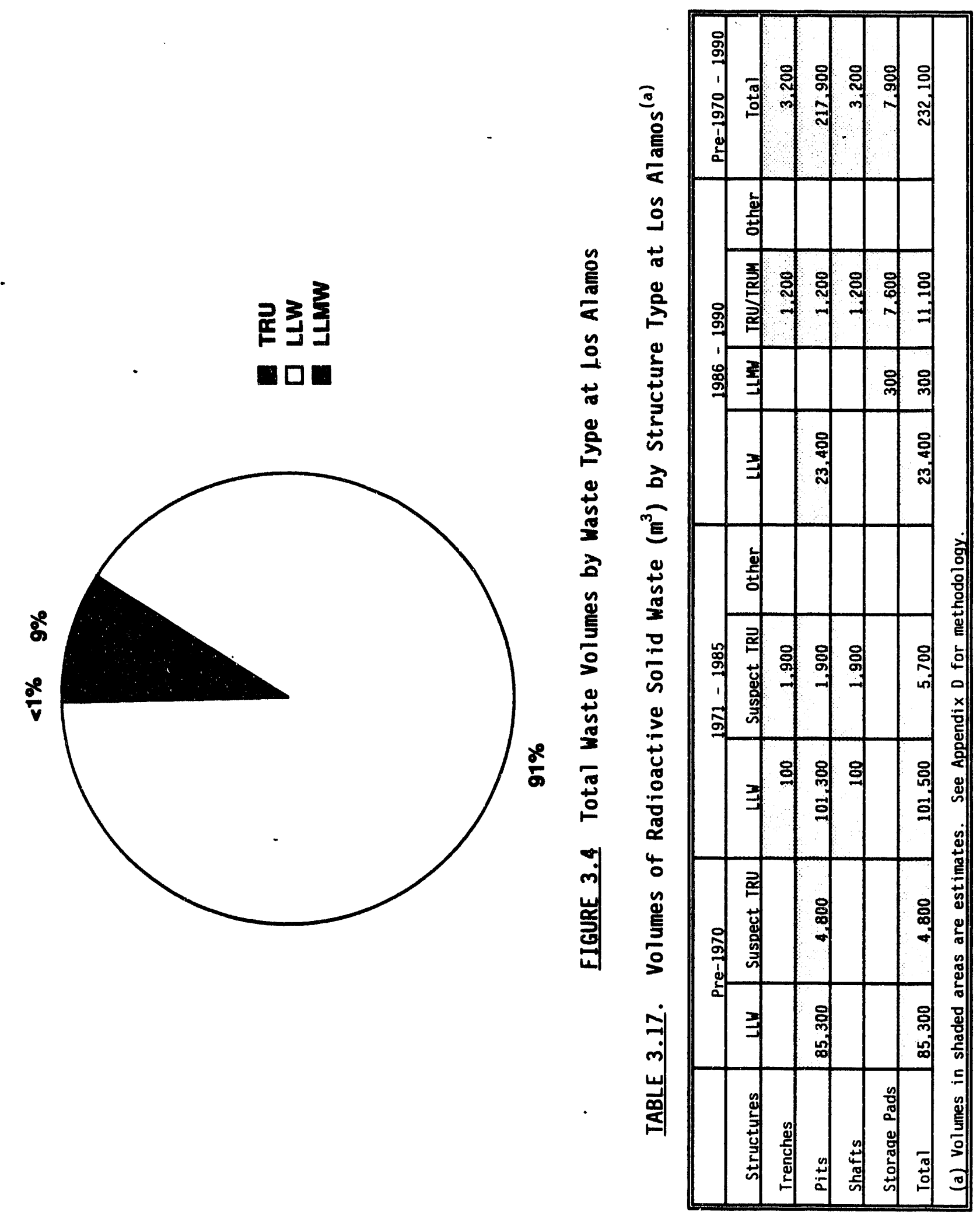


TABLE 3.18. Physical Characteristics of TRU Waste at Los Alamos $\left(\mathrm{m}^{3}\right)^{(a)}$

\begin{tabular}{|l|r|r|r|r|r|r|r|}
\hline & Sludges & Combustibles & $\begin{array}{c}\text { Non- } \\
\text { Combustibles }\end{array}$ & Particulates & Filters & Other & Total \\
\hline Trenches & 300 & 400 & 700 & 600 & 70 & 900 & 3,100 \\
\hline Pits & 800 & 1,100 & 1.900 & 1,600 & 200 & 2,400 & 7,900 \\
\hline Shafts & 300 & 400 & 700 & 600 & 70 & 900 & 3,100 \\
\hline Storage Pads & 800 & 1.000 & 1,800 & 1,500 & 200 & 2.300 & 7,600 \\
\hline Total & 2,200 & 2,900 & 5.200 & 4,300 & 500 & 6,500 & 21,600 \\
\hline (a) Volumes in shaded areas are estimates. See Appendix D for methodology. & & \\
\hline
\end{tabular}

TABLE 3.19. Physical Characteristics of LLW and LLMW at Los Alamos $\left(\mathrm{m}^{3}\right)^{(\mathrm{a})}$

\begin{tabular}{|l|r|r|r|r|r|r|r||}
\hline & $\begin{array}{r}\text { Bio- } \\
\text { logical }\end{array}$ & $\begin{array}{r}\text { Contaminated } \\
\text { Equipment }\end{array}$ & Debris & Dry Sol ids & $\begin{array}{r}\text { Sol idified } \\
\text { Siudges }\end{array}$ & Other & Total \\
\hline Trenches & 0 & 20 & 10 & 60 & & 0 & 90 \\
\hline Pits & 400 & 53,600 & 12,500 & 143,200 & & 230 & 210,000 \\
\hline Shafts & 0 & 20 & 10 & 60 & & 0 & 90 \\
\hline Storage Pads & 0 & 80 & 20 & 200 & & 0 & 300 \\
\hline Total & 400 & 53,800 & 12,500 & 143,600 & & 200 & 210,500 \\
\hline (a) Volumes in shaded areas are estimates. See Appendix D for methodology. & & & \\
\hline
\end{tabular}

TABLE 3.20. Hazardous Constituents of LLMW at Los Alamos ${ }^{(a)}$

\begin{tabular}{||l|c|c|c|c|c|c|c||}
\hline & Ignitable & Reactive & Corrosive & Toxic & $\begin{array}{c}\text { Listed RCRA } \\
\text { Wastes }\end{array}$ & PCBs & Total \\
\hline Trenches & & & & & & & \\
\hline Pits & & & & & & & \\
\hline Shafts & & & & & & & \\
\hline Storage Pads & 10 & 0 & 10 & 60 & 200 & & 300 \\
\hline Storage Buildings & & & & & & & \\
\hline Total & 10 & 0 & 10 & 60 & 200 & & 300 \\
\hline (a) Volumes in shaded areas are estimates. See Appendix D for methodology. & \\
\hline
\end{tabular}


Tables 3.18 and 3.19 describe the physical characteristics of the TRU and $L L W$ at Los Alamos. The hazardous constituents of the mixed waste are delineated in Table 3.20.

\subsubsection{Oak Ridge Site}

The areas that contain buried radioactive solid waste at the Oak Ridge facility include the Solid Waste Storage Area (SWSA) 1, SWSA 2, SWSA 3, SWSA 4, SWSA 5, and SWSA 6. Records for the amounts and types of radionuclides present in SWSAs 1 and 2 do not exist, and both sites are now closed. The wastes buried in SWSA 2 have since been removed.

Records of waste buried in SWSAs 3, 4, and part of 5 were destroyed by a fire in 1957. (a) Therefore, information on the waste buried in these areas is extremely limited. However, SWSAs 3, 4, and 5 are known to have several shallow trenches for TRU and LLW disposal.

SWSA 5 contains most of the TRU waste storage facilities at Oak Ridge. Contact-handled (CH) TRU waste in drums and boxes is stored in below-grade facilities constructed of concrete blocks. Retrievable remote-handled (RH) TRU in concrete casks is stored in a bunker. Non-retrievable RH TRU in casks is buried in trenches.

TRU waste at Dak Ridge has many different forms. Contact-handled TRU consists of paper, glass, plastic, shoe covers, and other miscellaneous waste from glovebox operations, and is usually stored in 55-gallon drums and $4 \times 4 \times$ $6-\mathrm{ft}$ boxes. This RH TRU waste consists of paper, glass, plastic tubing, and other miscellaneous waste from cell waste, HEPA filters, and discarded equipment. Remote-handled (RH) TRU is typically contained in cylindrical concrete casks $4.5 \mathrm{ft}$ in diameter and $7.5 \mathrm{ft}$ high; smaller containers such as 3-gallon plastic buckets, 1-gallon paint cans, and 5-gallon metal cans are also used to package this waste before it is placed into the concrete casks.

SWSA 6 has been used since 1969. It is an active disposal site for LLW and contains both above-grade and below-grade disposal units. Below-grade

(a) Letter, R. C. Mason (ORNL) to D. L. Stiles (PNL). March 20, 1992.

"Request for ORNL Waste Characterization Data for BWID Project." 
disposal units used at 0ak Ridge include silos, double-walled pipe wells, pipe-lined auger hole wells, and trenches. Beginning in 1986, certain solid waste management practices were initiated in SWSA 6 ; some areas of SWSA 6 were remediated under RCRA interim status closure and greater confinement disposal techniques were implemented. Current $\mathrm{plans}$ are to phase out below-grade disposal in SWSA 6 by December 1993 and begin closure of the site.

LLW at Oak Ridge has several different forms. LLW consists of compactible waste such as plastic bags, paper, light-gauge metal, and glass. Noncompactible LLW consists of heavy-gauge metal items and wood. Contact-handled (CH) LLW is also made up of solidified sludges, biological material, and debris contaminated with asbestos.

The above-grade disposal structure used at Oak Ridge is called a tumulus. Containerized LLW is loaded into rectangular vaults, stacked, placed on a curbed concrete pad, and covered with natural materials. Beginning in 1994, LLW will be disposed only in the above-grade tumulus Interim Waste Management Facility (IWMF). The IWMF will be closed in the early 2000 s and new LLW disposal facilities are expected to begin operation (Martin Marietta 1991).

Figure 3.5 shows the makeup of the solid waste buried and stored at 0ak Ridge $(X-10)$. Ninety-six percent of the total volume is LLW, $3 \%$ is TRU, and $1 \%$ is LLMW stored at the site since 1986. A summary characterization of waste at Oak Ridge $(X-10)$ is provided in Tables 3.21 through 3.24. The volumes shown in Table 3.21 are based upon a qualitative assessment of the best available information found during this study, primarily upon the IDB. The assumptions used to generate the estimates shown in the table are given in Appendix E.

Tables 3.22 and 3.23 describe the physical characteristics of the TRU and LLW at Oak Ridge $(X-10)$. The hazardous constituents of the mixed waste are delineated in Table 3.24.

\subsubsection{Rocky Flats Site}

The Rocky Flats Site currently has two isolated areas containing buried solid waste: the 900 Area and the Original Plant site outside the 


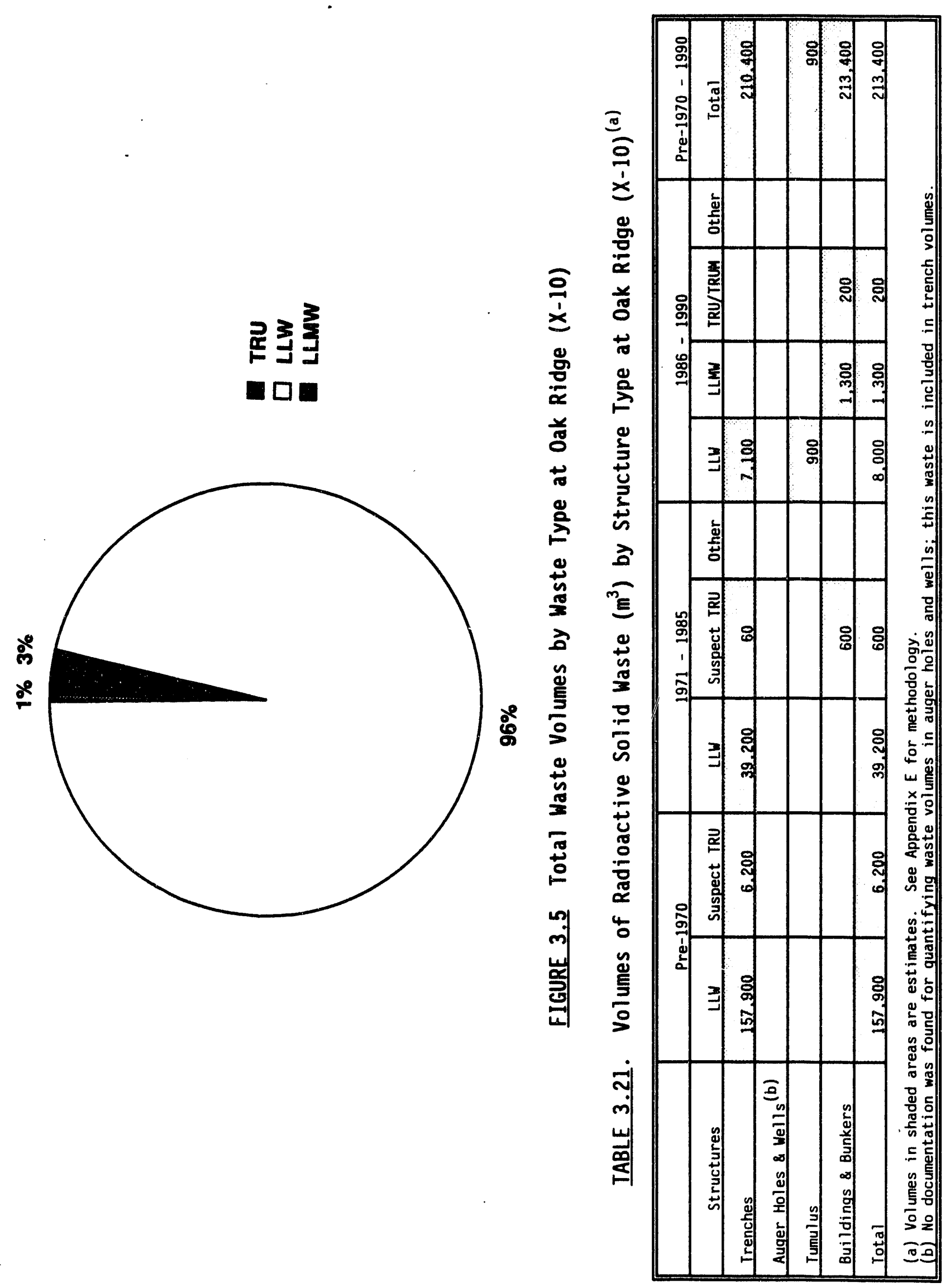


TABLE 3.22. Physical Characteristics of TRU Waste at Oak Ridge $(X-10)\left(m^{3}\right)^{(a)}$

\begin{tabular}{|l|r|r|r|r|r|r|r|}
\hline & Sludges & Combustibles & $\begin{array}{c}\text { Non- } \\
\text { Combustibles }\end{array}$ & $\begin{array}{c}\text { Par- } \\
\text { ticulates }\end{array}$ & Filters & Other & Total \\
\hline Trenches & 2,700 & 2,100 & 1,300 & 20 & 100 & 40 & 6.300 \\
\hline Auger Hoes \& Wells & & & & & & \\
\hline Tumulus & & & & & & \\
\hline Buildings \& Bunkers & 400 & 1300 & 200 & 0 & 20 & 0 & 800 \\
\hline Total & 3,000 & 2,400 & 1,500 & 20 & 200 & 50 & 7,100 \\
\hline (a) Volumes in shaded areas are estimates. See Appendix E for methodology. & & \\
\hline
\end{tabular}

\section{TABLE 3.23. Physical Characteristics of LLW and LLMW at Oak Ridge $(\mathrm{X}-10)\left(\mathrm{m}^{3}\right)^{(\mathrm{a})}$}

\begin{tabular}{|c|c|c|c|c|c|c|c|}
\hline & $\begin{array}{c}\text { Bio- } \\
\text { logical }\end{array}$ & $\begin{array}{l}\text { Contaminated } \\
\text { Equipment }\end{array}$ & Debris & $\begin{array}{l}\text { Dry } \\
\text { Solids }\end{array}$ & $\begin{array}{l}\text { Solidified } \\
\text { Sludges }\end{array}$ & Other & Total \\
\hline Trenches & 32,300 & 74,600 & 7.900 & 63.600 & 21,900 & 3.900 & 204,100 \\
\hline \multicolumn{8}{|c|}{ Auger Holes \& Wells (b) } \\
\hline Tumulus & 100 & 300 & 40 & 300 & 100 & 20 & 900 \\
\hline Buildings \& Bunkers & & 500 & 200 & 400 & 200 & 50 & 1.300 \\
\hline Total & 32,500 & 75,400 & 8,100 & 64,000 & 22.300 & 3,900 & 206.300 \\
\hline
\end{tabular}

(a) Volumes in shaded areas are estimates. See Appendix $E$ for methodology.

(b) No documentation was found for quantifying waste volumes in auger holes and wells. This waste is included in trench volumes.

TABLE 3.24. Hazardous Constituents of LLMW at Oak Ridge $(X-10)\left(\mathrm{m}^{3}\right)^{(a)}$

\begin{tabular}{|l|c|c|c|c|c|c|c|}
\hline & Ignitable & Reactive & Corrosive & Toxic & $\begin{array}{c}\text { Listed RCRA } \\
\text { Wastes }\end{array}$ & PCBs & Total \\
\hline Trenches & & & & & & & \\
\hline Auger Holes \& Wells & & & & & & & \\
\hline Tumulus & & & & & & & \\
\hline Buildings \& Bunkers & 50 & & 0 & 60 & 1,200 & & 1,300 \\
\hline Total & 50 & & 0 & 60 & 1,200 & & 1,300 \\
\hline (a) Volumes in shaded areas are estimates. See Appendix E for methodology. & \\
\hline
\end{tabular}


security-fenced area. All other waste that was buried at the facility was removed during an onsite radiometric survey performed from 1975 to 1983 by Rockwell International Corporation.

The 900 Area and the Original Plant Site contain waste buried in trenches, landfills and pits. The burial trenches, which were used from 1954 to 1968 , contain depleted uranium, flattened depleted-uranium-contaminated drums, and sanitary sewer sludge; the waste is assumed to be LLMW.

The pits were used from 1956 to 1965 for burning depleted-uraniumcontaminated oils. These pits were closed and covered in place; the types and amounts of hazardous substances that may remain in these structures is unknown, but it is assumed that this waste is LLMW.

Two landfills exist at the Rocky Flats. The original onsite landfill was used from 1952 to 1968 for disposal of general plant wastes, but approximately $44 \mathrm{lb}$ of depleted uranium was also buried here (DOE 1986). The landfill has an estimated volume of $56,500 \mathrm{~m}^{3}$. The present 1 andfill was placed in service in 1968 and receives an estimated 9 million 16 of waste annually. Records show that this landfill received about 2200 1b of sanitary sewage sludge between 1968 and 1970 that potentially contains heavy metals and radioactivity.

All solid radioactive wastes currently generated at the RFP are packaged for treatment, decontaminated, or placed in drums to be shipped to an offsite DOE facility. Figure 3.6 shows the makeup of the solid waste buried and stored at Rocky Flats. Ninety percent of the total volume is TRU, and $10 \%$ is LLMW stored at the site. A summary characterization of waste at Rocky Flats is provided in Tables 3.25 through 3.28. The volumes shown in Table 3.25 are based upon a qualitative assessment of the best available information found during this study, primarily upon the IDB. The assumptions used to generate the estimates shown in the table are given in Appendix $F$.

Tables 3.26 and 3.27 describe the physical characteristics of the TRU and LLW at Rocky Flats. The hazardous constituents of the mixed waste are delineated in Table 3.28 . 


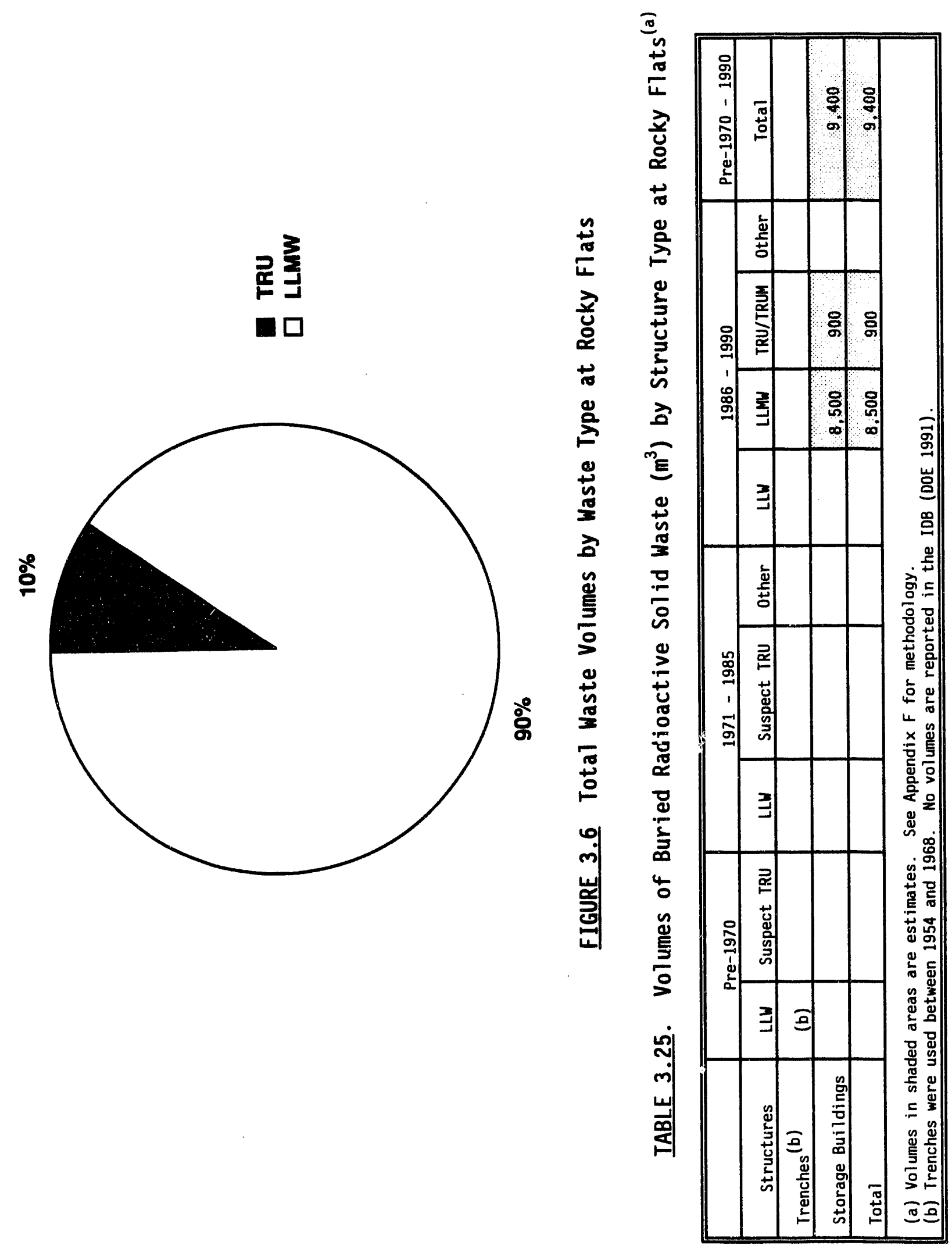


TABLE 3.26. Physical Characteristics of TRU Waste at Rocky Flats $\left(m^{3}\right)^{(a)}$

\begin{tabular}{|c|c|c|c|c|c|c|c|}
\hline & Sludges & Combustibles & $\begin{array}{c}\text { Non- } \\
\text { Combustibles } \\
\end{array}$ & $\begin{array}{c}\text { Par- } \\
\text { ticulates }\end{array}$ & Filters & Other & Total \\
\hline \multicolumn{8}{|l|}{ Trenches } \\
\hline Storage Buildings & 300 & 10 & 400 & 10 & 10 & 50 & 900 \\
\hline Total & 300 & 100 & 400 & 10 & 10 & 50 & 900 \\
\hline
\end{tabular}

IABLE 3.27. Physical Characteristics of LLW and LLMW at Rocky Flats $\left(\mathrm{m}^{3}\right)^{(a)}$

\begin{tabular}{|l|l|l|l|l|l|l|l||}
\hline & $\begin{array}{c}\text { Bio- } \\
\text { logical }\end{array}$ & $\begin{array}{c}\text { Contaminated } \\
\text { Equipment }\end{array}$ & Debris & $\begin{array}{c}\text { Dry } \\
\text { Solids }\end{array}$ & $\begin{array}{c}\text { Solidified } \\
\text { Sludges }\end{array}$ & Other & Total \\
\hline Trenches & & & & & & & \\
\hline Storage Buildings & & & & 8,500 & & 8.500 \\
\hline Total & & & & 8,500 & & 8,500 \\
\hline (a) Volumes in shaded areas are estimates. See Appendix F for methodology. & \\
\hline
\end{tabular}

TABLE 3.28. Hazardous Constituents of LLMW at Rocky Flats $\left(m^{3}\right)^{(a)}$

\begin{tabular}{|c|c|c|c|c|c|c|c|}
\hline & Ignitable & Reactive & Corrosive & Toxic & $\begin{array}{c}\text { Listed RCRA } \\
\text { Wastes }\end{array}$ & PCBs & Totã \\
\hline \multicolumn{8}{|l|}{ Trenches } \\
\hline Storage Buildings & 0 & & & 40 & 8,400 & 10 & 8.500 \\
\hline Total & 0 & & & 40 & 8,400 & 10 & 8,500 \\
\hline
\end{tabular}

\subsection{CHARACTERISTICS OF BURIED WASTE STRUCTURES}

This section addresses the environment within which the waste is contained as it relates to retrieval or in situ management techniques, and will include information on such things as typical trench profiles, overburden amounts, and possible plumes within the sediment.

\subsubsection{Overall Complex-Wide Summary}

This section identifies the major buried waste sites across the DOE complex. General information will be presented for each of the sites, e.g., 
typical trench designs and overburden amounts. This information will make possible a better understanding of the similarities and differences of the site-specific information presented in the following section.

\subsubsection{Site-Specific Information}

\subsubsection{Idaho National Engineering Laboratory}

The Radioactive Waste Management Complex (RWMC) contains the major amount of radioactive solid waste at INEL. The RWMC is 154 acres in area, and the burial ground within RWMC covers 88 acres. The average annual rainfall at INEL is $8.5 \mathrm{in.}$, and the water table is $200-600 \mathrm{ft}$ below the surface.

The soils consist mainly of silts, clays, and sands, with some gravel. In general, $85 \%$ of the sediments are clayey silts. Surface sediments range from 0-23 ft deep, and the average elevation is $5010 \mathrm{ft}$ above sea level.

Pits and trenches are the primary burial structures. A basalt layer underlies the burial ground, allowing a maximum depth of $20 \mathrm{ft}$ for burial. Some pits are only $5 \mathrm{ft}$ deep. Trenches and pits are generally excavated to bedrock and then backfilled 2-5 ft to level off the bottom.

Pits are quite large and have various shapes and dimensions. Trenches range from 100 to $1800 \mathrm{ft}$ in length, 5 to $8 \mathrm{ft}$ in width, and average $12 \mathrm{ft}$ in depth.

\subsubsection{Hanford}

100 Areas. Some of the small burial grounds in the 100 Areas consist of a single trench or pit. Pieces of equipment with high dose rates were generally placed in narrow, deep trenches and partially covered with earth fill. Small crib pits (e.g., $8 \times 8 \mathrm{ft}$ pits made from railroad ties) and vertical steel pipes and culverts approximately 5 to $6 \mathrm{ft}$ in diameter were often used for disposing of small reactor hardware with high dose rates.

All radioactive solid waste in the 100 Areas has been covered with a minimum of $4 \mathrm{ft}$ of clean soil stabilized with gravel. Herbicides are used to keep deep-rooted plants from growing over the burial grounds. 
Burial trenches are approximately $20 \mathrm{ft}$ deep. The water table in the 100 Areas varies from 55 to $80 \mathrm{ft}$ in some parts to approximately $33 \mathrm{ft}$ in others.

200 Areas. Solid wastes are buried in trenches and caissons in the 200 Areas. Caissons primarily consist of a below grade, vertical silo approximately $12 \mathrm{ft}$ high by $6 \mathrm{ft}$ in diameter. Caissons are used for disposal of high-activity LLW and high-activity TRU.

Waste in the 200 Areas is also buried in two types of $t_{1}$ inches: a $V$-trench and an industrial trench. $V$-trenches at Hanford are typically $16 \mathrm{ft}$ deep with a base 0 to $16 \mathrm{ft}$ wide. Slopes of this type of trench vary from $1: 1$ to 1.5:1; they are covered with a minimum of $8 \mathrm{ft}$ of soil. An industrial trench can be as deep as $50 \mathrm{ft}$ and has a wide bottom, typically 16 to $100 \mathrm{ft}$ wide. Approximately $8 \mathrm{ft}$ of, $0 i 1$ is used to cover the waste buried in this type of trench; $4 \mathrm{ft}$ of soil is used if the waste is to be retrieved later.

300 Area. The unsaturated zone is approximately $40 \mathrm{ft}$ deep, with sand to silty sand and gravelly sand making up the top layer (approximately $9 \mathrm{ft}$ deep) and sandy granule-pebble and sandy cobble-boulder gravel beneath it to the saturated zone.

\subsubsection{Savannah River Site}

Forty waste sites at the Savannah River Site have or might have received LLW or mixed waste. The $\mathbf{4 0}$ waste sites consist of basins, burning and rubble pits, the Ford Building waste site, the TNX burial ground, and the central radioactive waste burial grounds. This section of the report concentrates on the central radioactive burial grounds, where the major portion of buried radioactive solid waste is located.

The central radioactive burial grounds are located in Area $G$, between Areas $F$ and $H$. There are three major radioactive burial grounds: the initial, now inactive, burial ground, 643-G; the active LLW burial ground, 643-7G; and the inactive mixed waste landfill, 643-28G, which is entirely within the boundaries of 643-7G. The burial grounds are on relatively level land, $300 \mathrm{ft}$ above sea level. 
The soil underlying the burial grounds consists of $1000 \mathrm{ft}$ of mostly unconsolidated sands, sandy clays, and clays. Principal surface and nearsurface soil is clayey sands consisting of about one-third clay.

The mean water table is $40 \mathrm{ft}$ below ground and has a mean fluctuation of $2 \mathrm{ft}$, although fluctuations as great as $7 \mathrm{ft}$ have been observed. The average annual rainfall is $47 \mathrm{in}$. Groundwater is at least $10 \mathrm{ft}$ below the bottom of the radioactive waste trenches.

Cardboard and fiberboard boxes were used as final disposition containers until 1983 and were used in all three burial grounds. Rigid metal containers have been used in most cases since 1983 to allow for stacking. Rigid containers have included 55-gallon drums, $90-\mathrm{ft}^{3}$ metal boxes, $45-\mathrm{ft}^{3}$ boxes, and engineered (various sizes) boxes.

643-G. Radioactive wastes were buried in standard trenches in 643-G with $10 \mathrm{ft}$ of soil between trenches. Standard trenches are normally $20 \mathrm{ft}$ deep and $20 \mathrm{ft}$ wide with various lengths (different sources report the longest trenches as $300 \mathrm{~m}$ and $300 \mathrm{ft}$ long). The sides of the standard trenches are generally vertical.

Wastes were segregated by activity and buried in separate locations within the burial ground. Accurate records are maintained on the contents, radiation levels, and storage location of all waste. The locations of trenches are also documented.

Disposed wastes were generally in plastic bags, cardboard boxes, or bulk. Wastes were not stacked and were generally covered with a minimum of $4 \mathrm{ft}$ of overburden.

Between 1965 and 1972, TRU waste was segregated by activity. Waste containing radionuclides at less than $0.1 \mathrm{Ci} /$ package was buried unencapsulated in a segregated area until 1974. Wastes with TRU radionuclides at more than $0.1 \mathrm{Ci} /$ package have either been $\mathrm{placed}$ in prefabricated concrete containers, with inside dimensions of $6 \mathrm{ft}$ in diameter and $6.5 \mathrm{ft}$ in height and with 6-in.-thick walls, called culverts; or encapsulated in concrete. Culverts were buried under a minimum of $4 \mathrm{ft}$ of soil with a polyvinyl chloride sheet placed over the waste, $1 \mathrm{ft}$ under the soil surface. The general package used 
in culverts was 90-mil-thick polyethylene containers inside galvanized steel drums. TRU wastes with more than $0.1 \mathrm{Ci} /$ package that did not fit in culverts were encapsulated in a concrete pour called a monolith.

643-7G. 643-7G consists of standard trenches, engineered low-level trenches (ELLTS), greater confinement disposal (GCD) boreholes, and storage pads. ELLTs are $22 \mathrm{ft}$ deep with various widths and lengths, and generally have sloped (1:1) walls. Waste containers (e.g., metal boxes and drums) are stacked in ELLTs, unlike standard trenches where waste is dumped. ELLTs hold LLW (Savannah River LLW and ILW) primarily in carbon steel engineered boxes stacked four high in step fashion. Space between the sloped walls and stacked waste is filled with 55-gallon drums, bulky containerized waste, or dirty soil. Savannah River started using ELLTs in 1985.

Before 1985, the burial practices (e.g., containers, trenches) and treatment of TRU were identical to those used for 643-G. Since 1985, LLW has been buried in ELLTs in carbon steel engineered boxes or drums, and trench alpha waste has been buried in standard trenches (with depths of up to $27 \mathrm{ft}$ since 1987) with $6 \mathrm{ft}$ of gravel added to the bottom of the trenches for drainage. Low-level bulky items continued to be buried in standard trenches after 1985.

In 1974, TRU waste (greater than $10 \mathrm{nCi} / \mathrm{g}$ ) started to be stored above ground in polyethylene-1ined drums of 3/8-in. carbon steel on concrete pads. These were covered with a minimum of $4 \mathrm{ft}$ of soil until 1985. Bulky TRU has been stored in carbon steel boxes on concrete pads or in standard trenches (high-activity) with a minimum of $6 \mathrm{ft}$ of gravel in the bottom of the trench.

As of $1991 \mathrm{ILW}$, both containerized and non-containerized, is still disposed of in standard trenches, as is non-containerized LLW.

Some GCD facilities have been built for demonstration and are to be used for ILW. No waste had been stored in GCD facilities as of August 1991.

643-28G. 643-28G is an inactive closure facility for mixed waste located within the boundaries of 643-7G. There are a number of individual standard burial trenches and two container storage buildings. 


\subsubsection{Los Alamos National Laboratory}

There are 15 different areas that have been used for waste disposal at Los Alamos; at least nine may contain radioactive solid waste. A11 15 areas are located atop mesas underlain by a minimum of 250 feet of volcanic tuff. Average rainfall is $18 \mathrm{in}$. per year, and the water table is 600-1200 ft below the Pajarito Plateau, where Los Alamos is located. All waste is buried below the soil level in the volcanic tuff.

Pits and shafts are the two major burial structures. Pits generally range from 400-600 ft long, 25-100 ft wide, and 25-40 ft deep, and have very steep sloped sides (e.g., of the reported slopes in Area G, slopes range from $1: 4$ to $1: 12$ ). Shafts are generally 2-8 ft in diameter and 25-60 ft deep, and may be lined or unlined. Pits have a minimum of $3 \mathrm{ft}$ of mounded tuff over $3 \mathrm{ft}$ of excavated tuff for an overburden. Shafts are usually filled with tuff and capped with a $3-\mathrm{ft}$ concrete cap (to ground level) with an additional $3 \mathrm{ft}$ of mounded concrete added above ground.

Waste is generally thrown into the burial pits, except for sludge drums that have been stacked in the pits since 1971 for possible retrieval. Early practice was to fill the pit with waste and then cover with tuff. Wastes are now layered in the pits with 6 in. of backfill placed over each layer.

Area A. Area $A$ has nine disposal pits and two storage tanks. The pits used in the 1940s are $12 \mathrm{ft}$ deep and $15 \mathrm{ft}$ wide. The pit used for building debris in the 1960s and 1970s is $22 \mathrm{ft}$ deep. The other dimensions of the debris pit differ with different reports. The tanks in Area $A$ are $12 \mathrm{ft}$ in diameter and $62 \mathrm{ft}, 10 \mathrm{in}$. long. The tanks are in 12-ft-deep pits on 4-ft, 10 -in. concrete piers ( $2 \mathrm{ft}$ below pit bottom). Sand fills the space below the tanks and packed earth fills the pit to ground level. Loose earth was used to $1.5 \mathrm{ft}$ above the tanks and then capped with an 8-in. slab of concrete, with another $1.5 \mathrm{ft}$ of earth placed over the slab.

Area B. Area $B$ contains at least five (the actual number is unknown) pits with estimated depths of 12 to $20 \mathrm{ft}$. Pits in Area B were filled with waste prior to backfilling. Subsidence was filled with clean concrete and dirt from construction sites. There is a chemical disposal trench $2 \mathrm{ft}$ wide, 
$40 \mathrm{ft}$ long, and $3 \mathrm{ft}$ deep. The western two-thirds of the area has been covered with asphalt and is being used as a public rental storage area. Approximately $3 \mathrm{ft}$ of additional covering was added in 1984.

Area C. Four pits measure $610 \times 40 \times 18 \mathrm{ft}$ deep, one is $110 \times 705 \times 18$ $\mathrm{ft}$ deep, one is $100 \times 505 \times 23 \mathrm{ft}$ deep, and a chemical pit is $25 \times 180 \times 12 \mathrm{ft}$ deep. There are also 107 shafts ranging from 1 to $2 \mathrm{ft}$ in diameter and from 10 to $25 \mathrm{ft}$ deep. The 1-ft-diameter shafts are lined with $1 \mathrm{ft}$ of concrete.

The pits are covered with $6 \mathrm{in}$. to $3 \mathrm{ft}$ of topsoil over $1.5 \mathrm{ft}$ of tuff.

Area $D$. Area $D$ was used for underground explosives testing. Two shafts, one $20 \times 30 \times 45 \mathrm{ft}$ deep and another $6 \times 8 \times 46 \mathrm{ft}$ deep, were constructed. Shaft sides were shored up with $2 \times 12$ in. timbers. Chambers for explosives testing were placed in the bottom of the shafts, which were then backfilled prior to testing.

Area $E$. Area $E$ was used for underground explosives testing and radioactive solid waste burial. There is one underground chamber similar to those discussed for Area $D$. There are six pits in Area E: Pits 1 through 4 are shallow, 6-7 ft deep. Pit 1 is $15 \times 75 \mathrm{ft}$, Pit 2 is $15 \times 45 \mathrm{ft}$, Pit 3 is approximately $5 \mathrm{ft}$ in diameter, and Pit 4 is $15 \times 100 \mathrm{ft}$. Pits 5 and 6 are 12 $\times 80 \mathrm{ft}$ and $12 \times 63 \mathrm{ft}$, respectively, and have no waste reported.

Area $F$. Very little reliable information exists for Area $F$. Area $F$ is reportedly composed of shallow pits and trenches ranging in size from $2 \times 2 \times$ $4 \mathrm{ft}$ deep to $40 \times 70 \times 4 \mathrm{ft}$ deep.

Area $G$. Area $G$ is an active burial ground containing waste pits, shafts, three trenches, and two tanks. There are at least 30 pits in Area G; some large pits are $100 \times 600 \times 25 \mathrm{ft}$ deep. Smaller pits are of various sizes, but the general range is from 100 to $600 \mathrm{ft} 1 \mathrm{ong}, 25$ to $100 \mathrm{ft}$ wide, and 25 to $40 \mathrm{ft}$ deep.

Most of the TRU waste is currently stored on four asphalt pads measuring $40 \times 408 \mathrm{ft}$. Uncertified TRU waste packages, drums, and crates are stacked 12 to $16 \mathrm{ft}$ high. As the waste accumulates, the tops and sides are covered with plywood, and the entire stack is enclosed with nylon-reinforced vinyl 
sheeting. The stack is then covered with 3 to $6 \mathrm{ft}$ of tuff to create an artificial mound. A burial pit for TRU waste storage was handled in a similar manner.

Most of the LLW within the area is in pits, shafts, and trenches, and on pads of varying dimensions. Maximum land usage has been achieved by leaving minimal space between burial structures and by placing TRU and LLMW storage pads and buildings on top of older LLW burial pits.

Pit 9 is used for storing retrievable TRU. The bottom of Pit 9 has been graded and paved with asphalt.

Pit 19 has alpha contamination and "Cancer Suspect Research" waste. The alpha-contaminated waste on the bottom of the trench was covered with a plastic liner and 6 in. of tuff to keep the alpha contamination from spreading to the cancer research waste.

Use of disposal shafts in Area $G$ started in 1966. Shafts range from 1 to $6 \mathrm{ft}$ in diameter and from 25 to $60 \mathrm{ft}$ in depth. Lined, 3-ft-diameter shafts have a 12 in. diameter, 1 -ft-thick metal tube as a liner, with cement surrounding the liner.

Three trenches hold casks of wastes that have emitted or are emitting nuclear heat or radiation or are forming radiolytic gas. All three trenches are $13 \mathrm{ft}$ wide; $A$ and $B$ are $6 \mathrm{ft}$ deep, and $C$ is $8 \mathrm{ft}$ deep. $A$ and $B$ have 2-ft-deep, 3-ft-diameter holes augured into the bottom of the trenches. Concrete casks, each holding two 30-gallon drums, are placed in each hole and sealed with an asphalt material; they are arranged in arrays of 20 casks. Arrays are separated by $5 \mathrm{ft}$ of crushed tuff. Each array is covered with corrugated "Q-Decking." The hole is backfilled with tuff to the cask rims. After the "Q-Decking" has been put in place, another $3 \mathrm{ft}$ of crushed tuff is used as covering. Trench $A$ contains 120 casks; trenches $B$ and $C$ contain 100 casks each.

Area $T$. Area $T$ has $15-65-\mathrm{ft}$ deep shafts with diameters ranging from 6 to $8 \mathrm{ft}$ for liquid waste mixed with cement. Fifty-six of the 62 shafts contain TRU. Retrievable TRU is mixed with cement and pumped into $20 \mathrm{ft} \times 30$ in. 
sections of corrugated metal pipe and placed vertically in a $120 \times 24 \times 19 \mathrm{ft}$ deep pit. Each end of the pipes has a $1-\mathrm{ft}$ concrete cap.

The 115 absorption beds in Area T are $120 \times 20 \times 4 \mathrm{ft}$ deep. The beds have had the material at the bottom removed and have been filled with $2 \mathrm{ft}$ of stone, 6 in. of gravel, 6 in. of sand, and 12 in. of earth.

\subsubsection{Oak Ridge National Laboratory}

The geologic formations present at the Oak Ridge Reservation are of sedimentary origin, either limestone, dolomite, sandstone, or shale. The rock is covered by a mantle of residual alluvial and colluvial material up to $100 \mathrm{ft}$ thick. The water table fluctuates from 1 to $67 \mathrm{ft}$ below the surface. The average annual precipitation measured in the Oak Ridge vicinity is $54.4 \mathrm{in.}$; the average snowfall is $10.4 \mathrm{in}$.

Burial structure description data has primarily been compiled for SWSA 6. SWSA 6 has used a variety of techniques for disposal, of which most are positioned below grade. These include concrete silos, wells in silos, doublewalled pipe wells, lined auger holes, and unlined trenches. The tumulus is the only above-grade disposal structure used in the SWSA 6.

All RH LLW $>1 \mathrm{rem} / \mathrm{h}$ is shipped to SWSA 6 in shielded, bottom-unloading casks and disposed of in the various types of wells. The type of well facility used depends largely upon the configuration of the waste package.

Concrete silos are used for most CH LLW and some RH LLW less than $1 \mathrm{rem} / \mathrm{hr}$ and are located in separate areas of SWSA 6. These silos are constructed of two 16-gauge, corrugated steel pipes, one $8 \mathrm{ft}$ and the other $9 \mathrm{ft}$ in diameter. The smaller pipe is placed concentrically inside the larger pipe, and both are placed vertically in a trench. The annular space between the two pipes is filled with concrete. The pipes range from 14 to $20 \mathrm{ft}$ in length, depending upon the depth of the water table at a given location. A wire-reinforced, 12-in.-thick concrete pad is poured in the bottom of the silo. The silos are aligned in clusters within a trench. The depth of the trench is always located and dug with its lowest point a minimum of $2 \mathrm{ft}$ above the maximum water table elevation. 
Fill dirt is placed around the silos, leaving the tops of the silos at grade. More fill is added as required to compensate for settling; this facilitates water runoff away from the silo. The silo is capped with a 12-in.-thick, steel-reinforced concrete cap, and used for CH and RH LLW.

Concrete silos with containment wells are a modified version of the concrete silo described above and are used for disposal of RH LLW (> 1 rem/ $\mathrm{hr}$ ). Seven to eleven 20-in.-diameter by 20-ft-long cast iron pipes are placed vertically in a geometric array within the $8-\mathrm{ft}$ inside diameter of the concrete silo. The annular space between the outside surface of the cast iron pipes and the inside surface of the concrete silos is filled with concrete. A 12- to 18-in. concrete base is poured into each pipe. Each pipe is filled to within $3 \mathrm{ft}$ of the surface with waste and sealed with concrete.

Double-walled pipe wells are used for some RH LLW ( $1 \mathrm{rem} / \mathrm{hr}$ ) contained in 55-gallon drums. These wells are constructed of two 11-gauge, corrugated steel drainage pipes $20 \mathrm{ft}$ long placed in a drilled auger hole; one pipe is $36 \mathrm{in.}$ in diameter and the other is $30 \mathrm{in}$. in diameter. The 30-in.-diameter pipe is placed concentrically inside the 36-in.-diameter pipe, with the tops of the pipes at ground level. The bottom of the well is a minimum of $2 \mathrm{ft}$ above the maximum water table elevation. The space between the two pipes is filled with a concrete grout. A wire-reinforced, 12-in.-thick concrete plug is poured in the bottom of the well.

Only radioactive waste packaged in a 55-gallon drums is placed in the double-walled pipe well. The maximum radiation reading over the top of an open well must not exceed $200 \mathrm{mrem} / \mathrm{hr}$. No limits exist on the amount of radioactive material $\mathrm{placed}$ in the well provided the radiation reading at the top is not exceeded. When the well is filled, it is capped with a 12-in.-thick, 48-in. outside diameter concrete collar. After closing and capping the well, the radiation reading over the top of the well must be less than $2.5 \mathrm{mrem} / \mathrm{hr}$.

Pipe-lined auger hole wells are also used to dispose of some very highactivity RH LLW. These are constructed of a 3/4-in.-thick cast iron pipe vertically centered in a drilled auger hole; the surrounding space is backfilled 
with dirt. The pipes are $20 \mathrm{ft}$ long and have an inside diameter of $20 \mathrm{in.}$ A 12 -in.-thick concrete plug is poured in the bottom of the auger hole.

Very high-activity ( $>1 \mathrm{rem} / \mathrm{hr}$ ) RH LLW in. waste containers $20 \mathrm{in.}$ in diameter are placed in these wells. After an auger hole is filled, the hole is capped with a 12-in.-thick, 48-in. outside diameter concrete collar. After closing and capping the hole, the radiation reading over the top of the hole must be less than $2.5 \mathrm{mrem} / \mathrm{hr}$.

Trenches are used for disposal of biological waste. The trenches are approximately $50 \mathrm{ft}$ long and $10 \mathrm{ft}$ wide; the depth depends upon the water table elevation. The lowest point in the trench is at least $2 \mathrm{ft}$ above the known maximum water table elevation. Spacing between adjacent trenches is at least $5 \mathrm{ft}$. Trenches are graded to slope to one end at a rate of approximately $0.5 \mathrm{in.} / \mathrm{ft}$. Surface water drainage is controlled by separate ditching around the trench that conforms to existing topographic conditions. Trenches are sectioned by removable steel plates to improve efficiency of land usage and prevent sidewall collapse.

An open landfill in the northeast area of SWSA 6 is used for disposal of materials that register no external radiation but cannot be certified as free of contamination. This disposal area covers approximately one acre. Soil is used to cover the waste after disposal.

The above-grade disposal structure used at Oak Ridge is called a tumulus. Rectangular vaults approximately $7 \mathrm{ft}, 10 \mathrm{in}$. long are filled with containerized LLW. The void spaces are filled with concrete before the lid is piaced on the vault and sealed. Vaults are stacked on a curbed concrete pad and covered with natural materials. The pad is approximately $60 \times 90 \mathrm{ft}$, an average of 12 in. thick, and constructed of high-density concrete reinforced with epoxy-coated steel. A total of 510 vaults have been filled and placed on two tumulus pads. Beginning in 1994, LLW will be disposed only in the abovegrade tumulus Interim Waste Management Facility (IWMF). The IWMF will be closed in the early 2000s, and new LLW disposal facilities are expected to begin operation. (Martin Marietta 1991). 


\subsubsection{Rocky Flats Plant}

The Rocky Flats Plant currently has two isolated areas containing buried solid waste: the 900 area and the Original Plant Site outside the securityfenced area. All other waste that was buried at the site was removed during an onsite radiometric survey performed from 1975 to 1983 by Rockwell International Corporation.

The plant is located on a geological bench that slopes to the east at an average gradient of $95 \mathrm{ft}$ per mile. The land consists of stony soils made up of gravel and cobbles intermixed with sand and clay. The environment is arid with minimal rainfall, drying winds, and a porous gravel sediment. 


\subsection{OTHER CONTAMINATED SITES FOR WHICH BURIED WASTE TECHNOLOGIES MAY BE APPLICABLE}

This chapter addresses those sites at the six DOE facilities at which containerized wastes were not buried, but whose site characteristics are such that the technologies needed for retrieval and remediation of buried waste structures may generally be applicable. Examples of such sites include cribs, ditches, ponds, and basins.

The data used to summarize the information contained in this section were gathered from environmental release records for each DOE facility. These environmental releases, or release sites, include any site where spilling, leaking, discharging, leaching, or dumping of contaminants into the environment has occurred. The data quantifying the volumes of contaminated soils associated with these releases are based upon the size of the release site; additional volume of soils that may be associated with the release are not included. Therefore, the volumes reported in this section may understate the actual volume of contaminated soils.

Because each of the individual DOE facilities included in this assessment is at a different stage in developing the data required for this assessment, the completeness of the information summarized for each facility varies. Data for some of the facilities are quite limited and, at times, inconsistent with other facilities, because each has a different definition for a release site. For example, some sites only provide data on release sites that meet the EPA's definition of a Solid Waste Management Unit (SWMU). An SWMU is defined as "any discernable unit at which solid wastes have been placed at a time, irrespective of whether the unit was intended for the management of solid or hazardous wastes. Such units include any area at a facility where solid wastes have been routinely and systematically released" (55 FR 30808) (proposed subpart $S$ to the RCRA regulations in 40 CFR 264). Areas that treated or stored source, special nuclear, or by-product material as defined under the Atomic Energy Act are specifically excluded as required by federal regulations under RCRA (40 CFR 261.4(a)(4)). Both Los Alamos and the Hanford 
Site include all release sites from which or to which radioactive materials have been released. Consequently, the release sites identified by these two installations is more expansive.

For purposes of this assessment, a release site is defined as the lowest level of available information on an SWMU. These inconsistencies were resolved by identifying a common set of site and waste categories and then mapping each facility's categories into the BWID site categories delineated in Table 4.1.

Additional information was gathered for the contaminants associated with each of the release sites. Unfortunately, these data are limited because few of the release sites have been fully characterized. The waste categories used to describe the various sites include LLW, LLMW, TRU, TRUM, mixed heavy metals, mixed organics, and mixed heavy metals and organics. Definitions of these terms are provided in the glossary.

\subsection{OVERALL COMPLEX-WIDE SUMMARY}

An estimated 4.7 million $\mathrm{m}^{3}$ of contaminated soils are contained in aboveground liquid impoundments, below-ground liquid impoundments and disposal units, and other contaminated soil sites. An additional 1 million $\mathrm{m}^{3}$ of nonradioactive contaminated sites have been identified to date. However, only

TABLE 4.1. Site Types and BWID Site Categories

\begin{tabular}{||l|l||}
\hline $\begin{array}{c}\text { Complex-Wide Contaminated } \\
\text { Site Types }\end{array}$ & \multicolumn{1}{|c|}{ BWID Site Categories } \\
\hline $\begin{array}{l}\text { Contaminated soils } \\
\text { Pu-contaminated soils }\end{array}$ & Contaminated soils \\
\hline $\begin{array}{l}\text { Ponds } \\
\text { Ditches } \\
\text { Basins }\end{array}$ & Above-ground liquid impoundments \\
\hline Cribs & $\begin{array}{l}\text { Below-ground liquid impoundments, } \\
\text { disposal units }\end{array}$ \\
\hline
\end{tabular}


the radioactive contaminated soil sites are included in this preliminary assessment. The volumes of waste associated with each of these sites were given in Table 2.2.

At the time this report was compiled, volume and characterization information was found for nearly $30 \%$ of the contaminated sites across the DOE complex. Therefore, the volumes reported in this assessment are only for those sites that have been characterized, and could substantially understate the total volumes. This information is summarized in Table 4.2.

\subsection{SITE-SPECIFIC INFORMATION}

Only 506 of the 1795 sites are characterized well enough to assess the waste types (i.e., LLW, TRU, LLMW, TRUM, mixed heavy metals, mixed heavy metals and organics, nonradioactive hazardous materials, or nonradioactive nonhazardous materials) at each of the sites included in this assessment. Table 4.3 shows a breakdown for each of the sites and associated waste types. Approximately $70 \%$ of the total volume is LLMW, $18 \%$ is mixed heavy metals and organics, $8 \%$ of the waste is LLW, and $4 \%$ is made up of the remaining waste types.

Further details for total volume of waste at each of the DOE facilities are provided in the following sections.

TABLE 4.2. Other Contaminated Sites Throughout the DOE Complex

\begin{tabular}{||l|c|c|c||}
\hline & $\begin{array}{c}\text { Total Sites } \\
\text { Contaminated }\end{array}$ & $\begin{array}{c}\text { No. of Sites } \\
\text { With Data }\end{array}$ & Volume $\left(\mathrm{m}^{3}\right)^{(a)}$ \\
\hline $\begin{array}{l}\text { Above-Ground } \\
\text { Liquid Impoundment }\end{array}$ & 343 & 178 & $2,900,000$ \\
\hline $\begin{array}{l}\text { Below-Ground } \\
\text { Liquid Impoundment }\end{array}$ & 550 & 266 & 270,000 \\
\hline Contaminated Soils & 902 & 62 & $1,600,000$ \\
\hline TOTAL & 1,795 & 506 & $4,700,000$ \\
\hline (a) Volumes reported are for sites with data and have been rounded. \\
Volumes have not been extrapolated to include sites without data.
\end{tabular}


IABLE 4.3. Waste Types at Other Contaminated Sites Throughout the DOE Complex (Volumes in $\mathrm{m}^{3}$ )

\begin{tabular}{||c|c|c|c||}
\hline $\begin{array}{c}\text { Waste } \\
\text { Category }\end{array}$ & $\begin{array}{c}\text { Above-Ground } \\
\text { Liquid Impoundment }\end{array}$ & $\begin{array}{c}\text { Below-Ground } \\
\text { Liquid Impoundment }\end{array}$ & $\begin{array}{c}\text { Contaminated } \\
\text { Soils }\end{array}$ \\
\hline LLW & 350,000 & 53,000 & 2,200 \\
\hline TRU & 3,000 & 230 & \\
\hline LLW/TRU & 2,200 & 160 & \\
\hline LLMW & $1,600,000$ & 205,000 & $1,600,000$ \\
\hline TRUM & 140,000 & 11,008 & \\
\hline Mixed Heavy Metals & 14,000 & 1 & \\
\hline $\begin{array}{l}\text { Mixed Heavy Metals } \\
\text { and Organics }\end{array}$ & 860,000 & 10 & \\
\hline Mixed Organics & 160 & 4 & \\
\hline \hline
\end{tabular}

\subsubsection{Idaho National Engineering Laboratory (INEL)}

INEL has identified a total of 27 contaminated soil sites. The 19 sites that have been characterized account for approximately $870,000 \mathrm{~m}^{3}$ of contaminated soils in the DOE complex. A large portion of these are above-ground liquid impoundments that are contaminated with mixed heavy metals and organics. Data on these release sites were obtained from the Environmental Restoration Program Waste Management Unit Information for INEL. ${ }^{\text {(a) }}$

Table 4.4 shows a breakdown for each of the site types at INEL and the various waste types known to be present. Appendix A contains a table illustrating how INEL's site categories were mapped into the BWID categories developed for this document.

\subsubsection{Hanford}

The Hanford Site has identified a total of 751 contaminated soil sitis. The 330 that have been characterized account for approximately 2,000,000 $\mathrm{mi}^{3}$ of contaminated soils. Most of these sites are above-ground liquid

(a) Letter from Jerry Lyle (DOE-ID) to Steve Short (PNL) dated August 27, 1991. 
TABLE 4.4. Waste Types at Other Contaminated Sites at the INEL Facility (Volumes in $\mathrm{m}^{3}$ )

\begin{tabular}{||l|c|c|c||}
\hline & $\begin{array}{c}\text { Above-Ground } \\
\text { Liquid Impoundment }\end{array}$ & $\begin{array}{c}\text { Below-Ground } \\
\text { Liquid Impoundment }\end{array}$ & $\begin{array}{c}\text { Contaminated } \\
\text { Soils }\end{array}$ \\
\hline LLW & 110 & 4 & \\
\hline TRU & & $\cdot$ & \\
\hline LLW/TRU & & & \\
\hline Mixed Heavy Metals & 14,000 & 1 & \\
\hline $\begin{array}{l}\text { Mixed Heavy Metals } \\
\text { and Organics }\end{array}$ & 860,000 & 10 & \\
\hline LLMW & 120 & 15 & \\
\hline Mixed Organics & 160 & 4 & \\
\hline TRUM & & & \\
\hline
\end{tabular}

impoundments contaminated with LLMW. Data on these release sites were obtained from the Hanford Site Waste Management Units Report (DOE 1989), Hanford Site Waste Information Data System (1991) and the Environmental Site Information system available from the Waste Information Network (WIN).

Table 4.5 shows a breakdown for each of the site types at the Hanford Site and the various waste types known to be present. Appendix $B$ contains a table showing how Hanford's site categories were mapped into the BWID categories developed for this document.

\subsubsection{Savannah River}

The Savannah River Site has identified a total of 21 contaminated soil sites. The 18 sites that have been characterized account for approximately $100,000 \mathrm{~m}^{3}$ of contaminated soils. All of these are above-ground liquid impoundments contaminated with LLW. Data on these release sites were obtained from the Environmental Restoration Information System available on the WIN system and Waste Management Units-Savannah River Site (WSRC 1989).

Table 4.6 shows a breakdown for each of the site types at the Savannah River Site and the various waste types known to be present. Appendix $C$ 
IABLE 4.5. Waste Types at Other Contaminated Sites at the Hanford Facility (Volumes in $\mathrm{m}^{3}$ )

\begin{tabular}{|l|c|c|c|}
\hline & $\begin{array}{c}\text { Above-Ground } \\
\text { Liguid Impoundment }\end{array}$ & $\begin{array}{c}\text { Below-Ground } \\
\text { Liquid Impoundment }\end{array}$ & $\begin{array}{c}\text { Contaminated } \\
\text { Soils }\end{array}$ \\
\hline LLW & 240,000 & 53,000 & 90 \\
\hline TRU & & & \\
\hline LLW/TRU & & & \\
\hline Mixed Heavy Metals & & & \\
\hline $\begin{array}{l}\text { Mixed Heavy Metals } \\
\text { and Organics }\end{array}$ & & & \\
\hline Mixed LLW & $1,500,000$ & 200,000 & 37,000 \\
\hline Mixed Organics & & & \\
\hline Mixed TRU & 4,000 & 11,000 & \\
\hline
\end{tabular}

TABLE 4.6. Waste Types at Other Contaminated Sites at the Savannah River Facility (Volumes in $\mathrm{m}^{3}$ )

\begin{tabular}{|l|c|l|l|}
\hline & $\begin{array}{c}\text { Above-Ground } \\
\text { Liquid Impoundment }\end{array}$ & $\begin{array}{c}\text { Below-Ground } \\
\text { Liquid Impoundment }\end{array}$ & $\begin{array}{c}\text { Contaminated } \\
\text { Soils }\end{array}$ \\
\hline LLW & 110,000 & & \\
\hline TRU & & & \\
\hline LLW/TRU & & & \\
\hline Mixed Heavy Metals & & & \\
\hline $\begin{array}{l}\text { Mixed Heavy Metals } \\
\text { and Organics }\end{array}$ & & & \\
\hline Mixed LLW & & & \\
\hline Mixed Organics & & & \\
\hline Mixed TRU & & & \\
\hline
\end{tabular}


contains a table showing how Savannah River's site categories were mapped into the BWID categories developed for this document.

\subsubsection{Los Alamos}

Los Alamos has identified 626 contaminated soil sites. The 118 sites that have been characterized account for approximately $1,540,000 \mathrm{~m}^{3}$ of contaminated soils. Most of these sites are contaminated with LLMW. Data on these release sites were obtained from Los Alamos National Laboratory Solid Waste Management Units Report (LANL 1990).

Table 4.7 shows a breakdown for each of the site types at Los Alamos and the various waste types known to be present. Appendix D contains a table showing how Los Alamos site categories were mapped into the BWID categories developed for this document.

\subsubsection{Oak Ridge}

The Oak Ridge Site $(X-10)$ has identified 76 contaminated soil sites. The 17 sites that have been characterized account for approximately $140,000 \mathrm{~m}^{3}$

IABLE 4.7. Waste Types at Other Contaminated Sites at Los Alamos (Volumes in $\mathrm{m}^{3}$ )

\begin{tabular}{|l|c|c|c|}
\hline & $\begin{array}{c}\text { Above-Ground } \\
\text { Liquid Impoundment }\end{array}$ & $\begin{array}{c}\text { Below-Ground } \\
\text { Liquid Impoundment }\end{array}$ & $\begin{array}{c}\text { Contaminated } \\
\text { Soils }\end{array}$ \\
\hline LLW & & 15 & 4 \\
\hline TRU & & & \\
\hline LLW/TRU & & & \\
\hline Mixed Heavy Metals & & & \\
\hline $\begin{array}{l}\text { Mixed Heavy Metals } \\
\text { and Organics }\end{array}$ & & & \\
\hline Mixed LLW & 34,000 & & $1,5(10,000$ \\
\hline Mixed Organics & & 10 & \\
\hline Mixed TRU & 1,100 & & \\
\hline
\end{tabular}


of contaminated soils. Most of these are above-ground liquid impoundments. Data on these release sites were obtained from Oak Ridge Reservation SWMU Sites Database.

Table 4.8 shows a breakdown for each of the site types at Oak Ridge and the various waste types known to be present. Appendix E co.tains a table showing how Oak Ridge's site categories were mapped into the BWID categories developed for this document.

\subsubsection{Rocky Flats}

No contaminated soil sites are currently identified at Rocky Flats.

\subsubsection{Other DOE Sites}

Approximately $24,000 \mathrm{~m}^{3}$ of contaminated soils have been identified at other DOE sites, including Argonne National Laboratory, Fernald, Nevada Test Site, Pinellas, and the K-25 and $\mathrm{Y}-12$ Sites at Oak Ridge. Above-ground liquid impoundments have been characterized and account for approximately 22,000 $\mathrm{m}^{3}$ of contaminated soils. Table 4.9 shows a breakdown for each of the site types

TABLE 4.8. Waste Types at Other Contaminated Sites at Oak Ridge $(X-10)$ (Volumes in $\mathrm{m}^{3}$ )

\begin{tabular}{|l|c|c|c||}
\hline & $\begin{array}{c}\text { Above-Ground } \\
\text { Liquid Impoundment }\end{array}$ & $\begin{array}{c}\text { Below-Ground } \\
\text { Liquid Impoundment }\end{array}$ & $\begin{array}{c}\text { Contaminated } \\
\text { Soils }\end{array}$ \\
\hline LLW & 3,000 & & \\
\hline TRU & 3,000 & 230 & \\
\hline LLW/TRU & 2,200 & 160 & \\
\hline $\begin{array}{l}\text { Mixed Heavy Metals } \\
\text { Mixed Heavy Metals } \\
\text { and Organics }\end{array}$ & & & \\
\hline Mixed LLW & 6,200 & & \\
\hline Mixed Organics & & & \\
\hline Mixed TRU & 130,000 & & \\
\hline
\end{tabular}


TABLE 4.9. Waste Types at 0ther Contaminated Sites at other DOE Facilities (Volume in $\mathrm{m}^{3}$ )

\begin{tabular}{||l|c|c|c||}
\hline & $\begin{array}{c}\text { Above-Ground } \\
\text { Liquid Impoundment }\end{array}$ & $\begin{array}{c}\text { Below-Ground } \\
\text { Liquid Impoundment }\end{array}$ & $\begin{array}{c}\text { Contaminated } \\
\text { Soils }\end{array}$ \\
\hline LLW & 22,000 & 120 & 2,100 \\
\hline TRU & & & \\
\hline LLW/TRU & & 60 & \\
\hline Mixed Heavy Metals & & & \\
\hline $\begin{array}{l}\text { Mixed Heavy Metais } \\
\text { and Organics }\end{array}$ & & & \\
\hline
\end{tabular}

at each of these sites and the various waste types known to be present. Appendix $G$ contains-a table showing how "Other DOE Sites" contaminated soil categories were mapped into the BWID categories developed for this document. 


\subsection{INFORMATION SOURCES AND CONTACTS}

This section identifies the major information sources and contacts used in developing this report.

\subsection{INFORMATION SOURCES}

The major sources of information used to develop this report are listed below. Not all of the documents listed here are cited in the text. Many were used as background and supplementary material. These information sources were supplemented by contacts with various personnel throughout the DOE complex and are identified in the following section.

\subsection{REFERENCES}

55 FR 30800. 1990. Federal Register. Vol. 55, No. 145.

Idaho National Engineering Laboratory (INEL). 1976. Draft Environmental Impact Statement. ERDA-1536, Waste Management Operations, INEL, Idaho Falls, Idaho.

Los Al amos National Laboratory (LANL). 1987. Los Alamos National Laboratory Input for the Comprehensive Implementation Plan for DOE Defense Buried TRU Waste. LANL, Los Alamos, New Mexico.

Los Alamos National Laboratory (LANL). 1990. Los Alamos National Laboratory Solid Waste Management Units Report. LAUR 90-3400 Volumes I to IV, Los Alamos, New Mexico.

Mart in Marietta Energy Systems, Inc. 1991. Oak Ridge National Laboratory Waste Management Plan. ORNL/TM-11433/R1, Oak Ridge, Tennessee.

Miller, R. L., and R. K. Wahlen. 1987. Estimates of Solid Waste Buried in 100 Area Burial Grounds. WHC-EP-0087, Westinghouse Hanford Company, Richland, Washington.

Rogers, M. A. 1977. History and Environmental Setting of LANL Near-Surface Land Disposal Facilities for Radioactive Waste (Areas A, B, C, D, E, F, G, and I): A Source Document. Los Alamos National Laboratory, Los Alamos, New Mexico.

Stapp, D. C. 1993. Technology Needs for Remediation: Hanford and Other DOE Sites. PNL-8328, Pacific Northwest Laboratory, Richland, Washington. 
U.S. Department of Energy (DOE). 1986. Comprehensive Environmental Assessment and Response Program Phase I: Installation Assessment Rocky Flats Plant. DOE/NBM-6011476, DOE Field Office, Albuquerque, New Mexico.

U.S. Department of Energy (DOE). 1989. Hanford Site Waste Management Units Report. DOE/RL 88-30 Volumes 1 and 2, DOE Field Office, Richland, Washington.

U.S. Department of Energy (DOE). 1991. Integrated Data Base for 1991: U.S. Spent Fuel and Radioactive Waste Inventories, Projections and Characteristics. DOE/RW-0006 Rev. 7, DOE, Washington, D.C.

\subsection{BIBLIOGRAPHY}

Anderson, B. C., J. D. Anderson, J. A. Demiter, D. R. Duncan, and D. C. McCann. 1990. Contact-Handled Transuranic Waste Characterization Based on Existing Records. WHC-EP-0225, Westinghouse Hanford Company, Richland, Washington.

Arrenho1z, D. A., et al. 1991. Brief Analysis and Description of Transuranic Wastes in the Subsurface Disposal Area of the Radioactive Waste Management Complex at INEL. EGG-WTD-9438 Rev. 1, Idaho National Engineering Laboratory, Idaho Falls, Idaho.

Arrenholz, D. A., et al. 1991. Historical Report of Transuranic Waste Pits and Trenches at the Subsurface Disposal Area of the Radioactive Waste Management Complex at the INEL. WTD-91-027, Idaho National Engineering Laboratory, Idaho Fails, Idaho.

Bates, L. D. 1983. Radioactive Solid Waste Storage and Disposal at Oak Ridge National Laboratory, Description and Safety Analysis. ORNL/TM-8201, Union Carbide Corporation, Oak Ridge National Laboratory, Oak Ridge, Tennessee.

Brown, M. C. 1992. Quarterly Briefing Book on Environmental and Waste Management Activities. WHC-SP-0434-13, Westinghouse Hanford Company, Rich1 and, Washington.

Bullock, M. G., et al. 1987. Implementation Plans for Buried Transuranic Waste and Stored Special-Case Waste at the Idaho National Engineering Laboratory. EGG-WT-7610, Idaho National Engineering Laboratory, Idaho Falls, Idaho.

Coobs, J. H., and J. R. Gissel. 1986. History of Disposal of Radioactive Wastes Into the Ground at Oak Ridge National Laboratory. ORNL/TM-10269, Martin Marietta Energy Systems, Oak Ridge National Laboratory, Oak Ridge, Tennessee.

Dorian, J. J., and R. U. Richards. 1978. Radiological Characterization on the Retired 100 Areas. UNI-946, United Nuclear Inc., Richland, Washington. 
E. I. duPont de Nemours \& Co. 1988. Safety Analysis - 200 Area Savannah River Plant Burial Grounds Operations. DPSTA-200-10 Supp. 8, E. I. duPont de Nemours \& Co., Savannah River Laboratory, Aiken, South Carolina.

E. I. duPont de Nemours \& Co. 1989. Draft Savannah River Site Environmental Impact Plan. DPSP-87-121-2-1, E. I. duPont de Nemours \& Co., Aiken, South Carolina.

Jaegge, W. J., N. L. Kolb, B. B. Looney, I. W. Marine, O. A. Towler, and J. R. Cook. 1987. Environmental Information Document, Radioactive Burial Grounds.

DPST-85-694, E. I. duPont de Nemours and Co., Aiken, South Carolina.

Los Alamos Scientific Laboratory (LASL). 1979. Final Environmental Impact Statement for Los Alamos Srientific Laboratory Site. Los Alamos, New Mexico.

National Research Council. 1985. The Management of Radioactive Waste at the Oak Ridge National Laboratory: A Technical Review. National Academy of Sciences.

Rocky Flats Plant. 1990. Inactive Waste Unit Summary Sheets for Rocky Flats Plant, Revision No. 1. Rocky Flats Plant, Golder, C,olorado.

Savannah River Plant. 1977. Final Environmental Impact Statement. ERDA-1537, Waste Management Operations, Savannah River Plant, Aiken, South Carolina.

Sutherland, A., et a1. 1987. Performance Assessment of Closure Alternatives for the 643-G Site. Rogers \& Associates Engineering Corporation, Salt Lake City, Utah.

Trabalk, J.R. 1987. Buried TRU Wastes and TRU-Contaminated Soils at ORNL Remedial Action Program Sites: Program Strategy and Long-Range Planning. ORNL/RAP-8, Martin Marietta Energy Systems, Oak Ridge National Laboratory, Oak Ridge, Tennessee.

U.S. Department of Energy (DOE). 1979. Defense TRU Waste - Alternatives for Long-Term Management of Defense TRU Waste at the Savannah River Plant.

DOE/SR-WM-79-1, DOE, Aiken, South Carolina.

U.S. Department of Energy (DOE). 1987. Final Environmental Impact Statement, Waste Management Activities for Groundwater Protection, Savannah River Plant. DOE/EIS-0120, DOE, Aiken, South Carolina.

U.S. Department of Energy (DOE). 1989. Low-Level Burial Grounds Danqerous Waste Permit Application. DOE/RL 88-20 Volume 1, DOE Field Office, Richland, Washington.

U.S. Department of Energy (DOE). 1989. Low Level Burial Grounds, Danqerous Waste Permit Application. DOE/RL 88-20, DOE Field Office, Richland, Washington. 
U.S. Department of Energy (DOE). 1990. Remedial Investigation/Feasibility Study Work Plan for the 300-FF-5 Operable Unit, Hanford Site, Richland, Washington. DOE/RL 89-14, DOE Field Office, Richland, Washington.

U.S. Department of Energy (DOE). 1990. Department of Energy Waste Information. DOE/HWP-97, DOE, Washington, D.C.

U.S. Department of Energy (DOE). 1991. Environmental Restoration and Waste Management Site-Specific Plan for the Richland Operations Office. DOE/RL-91-25, DOE Field Office, Richland, Washington.

U.S. Department of Energy (DOE). 1991. Final Phase II RCRA Facility Investigation Remedial Investigation. Environmental Restoration Program, DOE Rocky Flats Office, Golden, Colorado.

U.S. Department of Energy (DOE). 1992. Final Environmental Impact Statement, Defense Waste Processing Facility, Savannah River Plant. DOE/EIS-0082, DOE, Aiken, South Carolina.

Vigil, M. J. 1989. Subsurface Disposal Area (SDA) Waste Identification (1952-1970) Emphasis). EGG-WM-8727-Rev. 1, EG\&G Idaho, Inc., Idaho Fa17s, Idaho.

Westinghouse Hanford Company (WHC). 1989. Characterization Study of LowLevel Mixed Waste in Retrievable Storage Units. WHC-EP-0245, WHC, RichTand, Washington.

Westinghouse Hanford Company (WHC). 1989. Stored, Contact-Handled Transuranic Waste Characterization at the Hanford Site. WHC-EP-0223, WHC, Richland, Washington.

Westinghouse Hanford Company (WHC). 1991. Summary of Radioactive Waste Received in 200 Areas During Calendar Year 1990. WHC, Richland, Washington.

Westinghouse Savannah River Company (WSRC). 1989. Waste Management Units Savannah River Site. WSRC-RP-89-898 Vol. 1 and 2, WSRC, Aiken, South Carolina.

Westinghouse Savannah River Company (WSRC). 1990. Savannah River Site Environmental Report. WSRC-IM-9128, WSRC, Aiken, South Carolina.

Westinghouse Savannah River Company (WSRC). 1991. Savannah River Site's Site Specific Plan. WSRC-RP-91-596, WSRC, Aiken, South Carolina.

\subsection{INFORMATION CONTACTS}

Table 5.1 provides a listing of the various people throughout the DOE complex who have provided input to this report or who have been identified as contacts for additional site-specific information. 
TABLE 5.1. Information Contacts for BWID Characterization Information

\begin{tabular}{|c|c|c|}
\hline Contact Name & Site & Telephone Number \\
\hline $\begin{array}{l}\text { Lee Norland } \\
\text { Buried Waste Program Manager }\end{array}$ & INEL & $208-526-8552$ \\
\hline $\begin{array}{l}\text { Jim Bischoff } \\
\text { Operations Manager/Radioactive Waste } \\
\text { Management Complex }\end{array}$ & INEL & $208-526-2766$ \\
\hline Jim Macanally & INEL & $208-526-2835$ \\
\hline Darlene Hagel & Hanford & $509-376-4394$ \\
\hline $\begin{array}{l}\text { Serena Galstad } \\
\text { Computer Support/Solid Waste } \\
\text { Engineering }\end{array}$ & Hanford & $509-376-4020$ \\
\hline Jim Anderson & Hanford & $509-376-4359$ \\
\hline $\begin{array}{l}\text { Ed Derr } \\
\text { EM-7 Waste Management Group }\end{array}$ & Los Alamos & $505-665-6151$ \\
\hline $\begin{array}{l}\text { E-Li Chen } \\
\text { EM-7 Waste Management Group }\end{array}$ & Los Alamos & $505-665-3961$ \\
\hline Barry Drennon & Los Alamos & $505-665-6496$ \\
\hline Ray Garde & Los Al amos & $505-668-7391$ \\
\hline Mike Ray & Los Al amos & $505-665-6496$ \\
\hline James Cook & Savannah River & $803-725-8183$ \\
\hline B. D. Helton & Savannah River & $803-725-5802$ \\
\hline Jim Stumbaugh & Savannah River & $803-557-1134$ \\
\hline voe Riddell & Savannah River & $803-557-8765$ \\
\hline Toni soore & Rocky Flats & $303-966-3005$ \\
\hline Allan Schubert & Rocky Flats & $303-966-5251$ \\
\hline Jeff Gilpin (Y-12) & Oak Ridge & 615-574-6809 \\
\hline TJ Abraham & Oak Ridge & $615-574-3378$ \\
\hline Darre11 Daugherty $(X-10)$ & Oak Ridge & $615-574-8996$ \\
\hline Jack Watson $(K-25)$ & Oak Ridge & 615-574-6795 \\
\hline Joe Haymore $(K-25)$ & Oak Ridge & $615-574-6795$ \\
\hline Nel son Lingle $(K-25)$ & Oak Ridge & $615-576-5580$ \\
\hline
\end{tabular}


TABLE 5.1. (contd)

\begin{tabular}{||l|l|l|}
\hline \multicolumn{1}{|c|}{ Contact Name } & \multicolumn{1}{|c|}{ Site } & Telephone Number \\
\hline Sidney Garland $(X-10)$ & Oak Ridge & $615-574-8581$ \\
\hline Doug Turner $(X-10)$ & Oak Ridge & $615-576-2017$ \\
\hline Willy Brown $(Y-12)$ & Oak Ridge & $615-574-2369$ \\
\hline Ron Dierolf (Paducah) & Oak Ridge & $502-441-6319$ \\
\hline Dennis Cope (Paducah) & Oak Ridge & $502-441-6129$ \\
\hline Terry Acox (Portsmouth) & Oak Ridge & $614-897-2331$ \\
\hline Richard Snyder (Portsmouth) & Oak Ridge & $614-975-2322$ \\
\hline Jim Bailey & Oak Ridge & $615-576-4489$ \\
\hline Jerome Miller & Oak Ridge & $615-544-3680$ \\
\hline Gary Conner (K-25) & Oak Ridge & $615-574-9019$ \\
\hline Clayton Gist (X-10) & Oak Ridge & $615-576-6821$ \\
\hline Norman Golchert & Argonne & $708-252-3912$ \\
\hline Kim Shippard & Livermore & $510-294-1475$ \\
\hline Wally Quaider & Fernald & $513-738-6160$ \\
\hline Robin Madisson & Nevada Test & Site \\
\hline Jim Griffin & Mound & $702-295-2834$ \\
\hline Kim Fraiser & Mound & $513-865-3831$ \\
\hline Jim Brangon & Pinellis & $813-865-3748$ \\
\hline & & \\
\hline
\end{tabular}




\subsection{GLOSSARY}

This glossary contains explanations of the terms, acronyms, and abbreviations used in this report.

ANL

Buried waste:

BWID

CH TRU

cpm

D\&D

DOE

ELLT

EPA

GCD

Hazardous waste: Under RCRA, any solid, liquid or combination of solid or liquid wastes, which, because of its physical, chemical or infectious characteristics, may pose a hazard when improperly managed. States (e.g., Washington) may impose further definition and restriction on hazardous wastes.

HEPA

HLW

ID

IDB

ILW

INEL

In situ

IWMF

Argonne National Laboratory

Solid waste, usually but not always containerized, placed in subsurface locations and covered with overburden for the purpose of disposal or extended storage

Buried Waste Integrated Demonstration

Contact-handled transuranic (waste)

counts per minute

Decontamination \& decommissioning

U.S. Department of Energy

Engineered low-level trenches

U.S. Environmental Protection Agency

greater confinement disposal

High-efficiency particulate air (filter)

High-level waste

Integrated demonstration

Integrated Data Base (maintained at ORNL)

Intermediate Level Waste

Idaho National Engineering Laboratory

Refers to treatment of contaminated areas in place, without excavation or other removal.

Interim Waste Management Facility 
LANL

LLMM

LLW

ORNL

OTD

RCRA

Release:

RFP

RH TRU

SNL

Sol id waste:

SRS

SWMU

TRU

TRUM

WIPP
Los Alamos National Laboratory

low-level mixed waste

Low-level waste

Oak Ridge National 1aboratory

DOE Office of Technology Development

Resource Conservation and Recovery Act; regulates management and disposal of hazardous wastes currently generated, treated, stored, disposed or distributed.

Any occurrence in which a regulated substance is emitted into air, scil or water.

Rocky Flats Plant

Remote-handled transuranic

Sandia National Laboratory

Any garbage, refuse or sludge, including solid, liquid, semisolid or contained gaseous material resulting from industrial, commercial, agricultural and mining operations, and community activities. Within the DOE complex, solid wastes are defined to exclude wastes contained in storage tanks, which are treated separately.

Savannah River Site

Sol id Waste Management Unit

Transuranic (waste)

Transuranic mixed (waste)

Waste Isolation Pilot Plant 
APPENDIX A

INEL BURIED WASTE STRUCTURE CHARACTERIZATION DETAILS 
APPENDIX A

INEL BURIED WASTE STRUCTURE CHARACTERIZATION DETAILS

Provided Structure Categories

Unplanned Releases

Acid Pond

Cooling Tower Basin

Disposal Pond

Ditch

Drainage Pond

Evaporation Pond

Lagoon

Leach Field

Leach Pond

Pond

Retention Basin

Waste Pond

Acid Pit

Disposal We11

French Drain

Injection Well

Neutralization Pits

Neutralization Sump

Valve Pit

Table A.1 contains an explanation of the methodology used in arriving at the estimated volumes of waste buried and/or stored at INEL.
BWID Structure Categories

Contaminated Soil

Above-Ground Liquid Impoundment

Below-Ground Liquid Impoundment/ Subsurface Disposal Unit

A. 1 


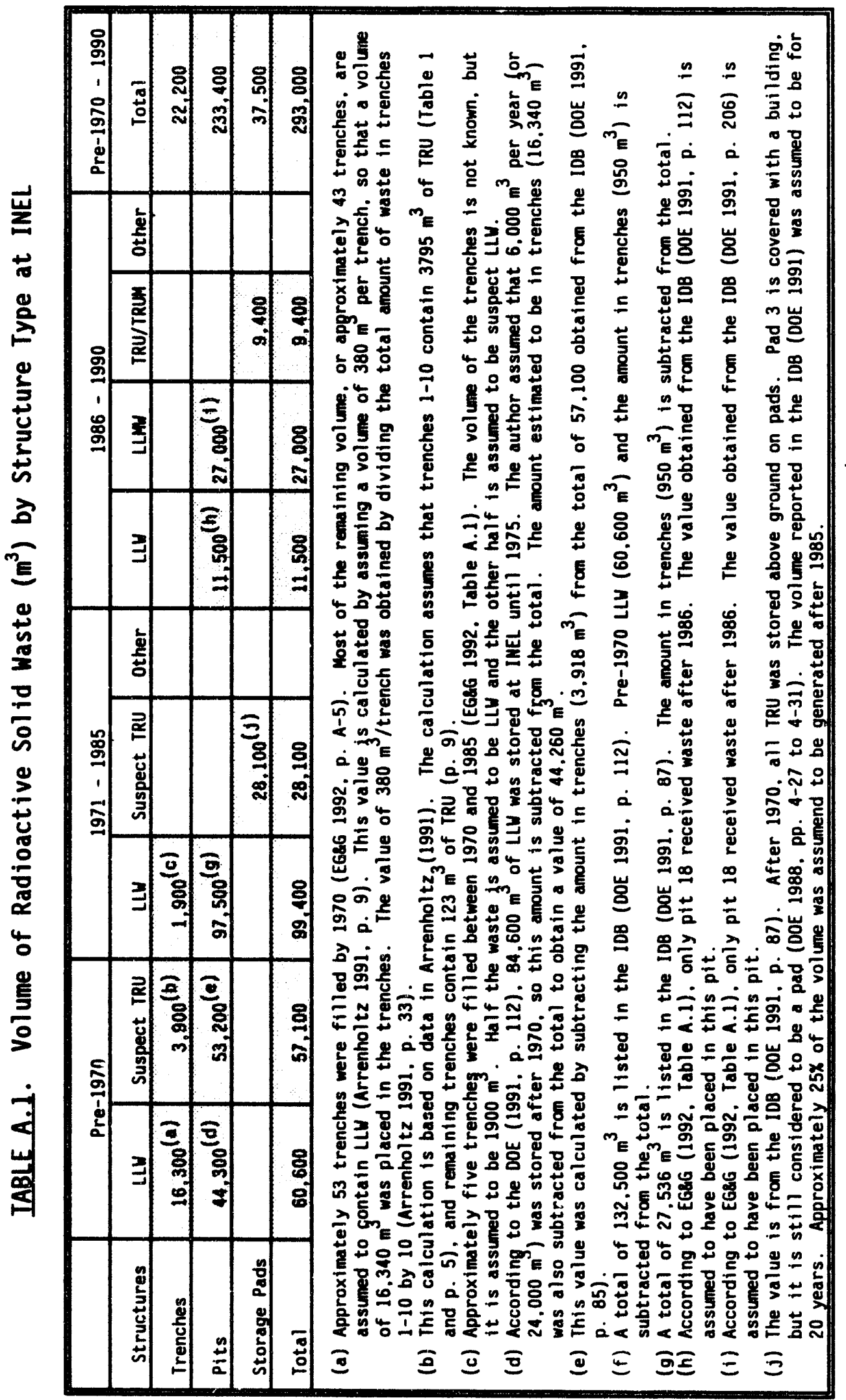

A. 2 


\section{REFERENCES}

Anderson, B. C., et al. 1990. Contact-Handled Transuranic Waste Characterization Based on Existing Records. WHC-EP-0225 Rev. 1, Westinghouse Hanford Company, Richland, Washington.

Arrenholtz, D. A., and J. L. Knight. 1991. Historical Report of Transuranic Waste Pits and Trenches at the Subsurface Disposal Area of the Radioactive Waste Management Complex at INEL. WTD-91-027, Idaho National Engineering Laboratory, EG\&G Idaho Inc., Idaho Falls, Idaho.

EG\&G Idaho, Inc. 1992. Thermal Processing System Concepts and Considerations for RUMC Buried Waste. EGG-WTD-10058, EG\&G Idaho Inc., Idaho Falls, Idaho.

U.S. Department of Energy (DOE). 1988. Environmental Survey Prel iminary Report. DOE/EH/OEV-22-P, DOE Idaho Field Office, Idaho Falls, Idaho.

U.S. Department of Energy (DOE). 1991. Integrated Data Base for 1991: U.S. Spent Fuel and Radioactive Waste Inventories, Projections, and Characteristics. DOE/RW-0006 Rev. 7, U.S. Department of Energy, Washington, D.C. 
APPENDIX B

HANFORD BURIED WASTE STRUCTURE CHARACTERIZATIOR DETAILS 


\section{HANFORD BURIED WASTE STRUCTURE CHARACTERIZATION DETAILS}

Provided Structure Categories

Unplanned Release

Ditch

Pond

Basin

Sand Filter

Trench

Brine Pit

Crib

Diversion Box

Drain Field

French Drain

Receiving We11

Reverse Well

Silo

Sump

Valve Pit

Table B.l contains an explanation of the methodology used in arriving at the estimated volumes of waste buried and/or stored at Hanford.

\section{BWID Structure Categories}

Contaminated Soil

Above-Ground Liquid Impoundment

Below-Ground Liquid Impoundment/ Subsurface Disposal Unit 


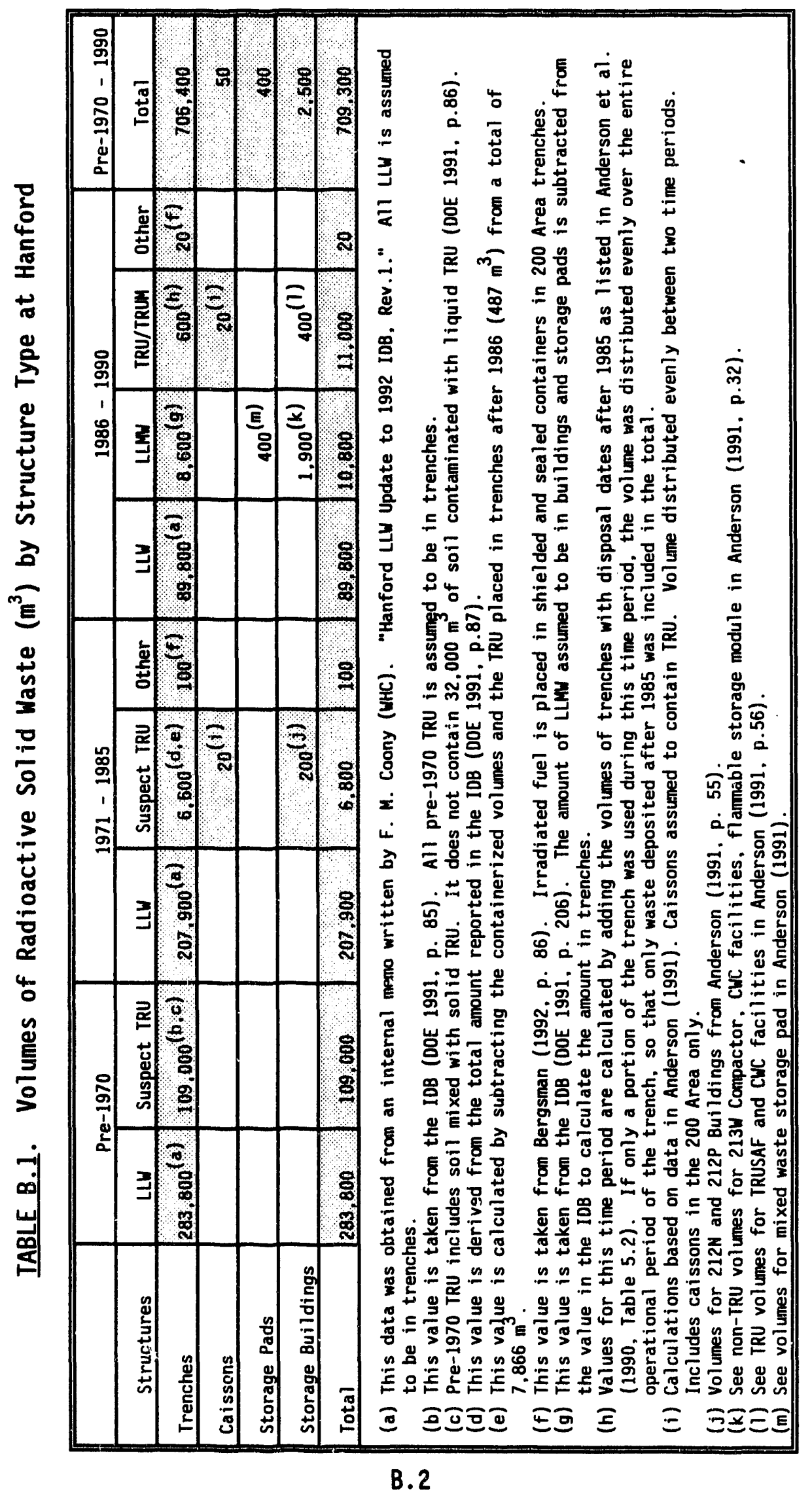




\section{REFERENCES}

Anderson, J. D., D. C. McCann, and B. E. Poremba. 1991. Summary of Radioactive Solid Waste Received in the 200 Areas During Calender Year 1990. WHC-EP-0125-3, Westinghouse Hanford Company, Richland, Washington.

Anderson, B. C., et al. 1990. Contact Handled TRU Waste Characterization Based on Existing Records. WHC-EP-0225, Westinghouse Hanford Company, Richland, Washington.

Bergsman, K. H. 1992. Hanford Irradiated Fuel Inventory Baseline.

WHC-SD-CP-TI-175 Rev.0, Westinghouse Hanford Company, Richland, Washington.

U.S. Department of Energy (DOE). 1991. Integrated Data Base for 1991: U.S. Spent Fuel and Radioactive Waste Inventories, Projections, and Characteristics. DOE/RW-0006 Rev. 7, DOE, Washington, D.C. 
APPENDIX C

SAVANNAH RIVER BURIED WASTE STRUCTURE CHARACTERIZATION DETAILS 


\section{APPENDIX C}

\section{SAVANNAH RIVER BURIED WASTE STRUCTURE CHARACTERIZATION DETAILS}

Provided Structure Categories

General Surface Soil

General Surface Soil Conatamination

Above-Ground Liquid Impoundment

Above-Ground. Storage Facility

Below-Ground Liquid Impoundment Industrial Waste System

Septic System
BWID Structure Categories

Contaminated Soi1

Above-Ground Liquid Impoundment

Below-Ground Liquid Impoundment/ Subsurface Disposal Unit

Table C.1 contains an explanation of the methodology used to arrive at the volumes of waste stored and/or buried at Savannah River. 


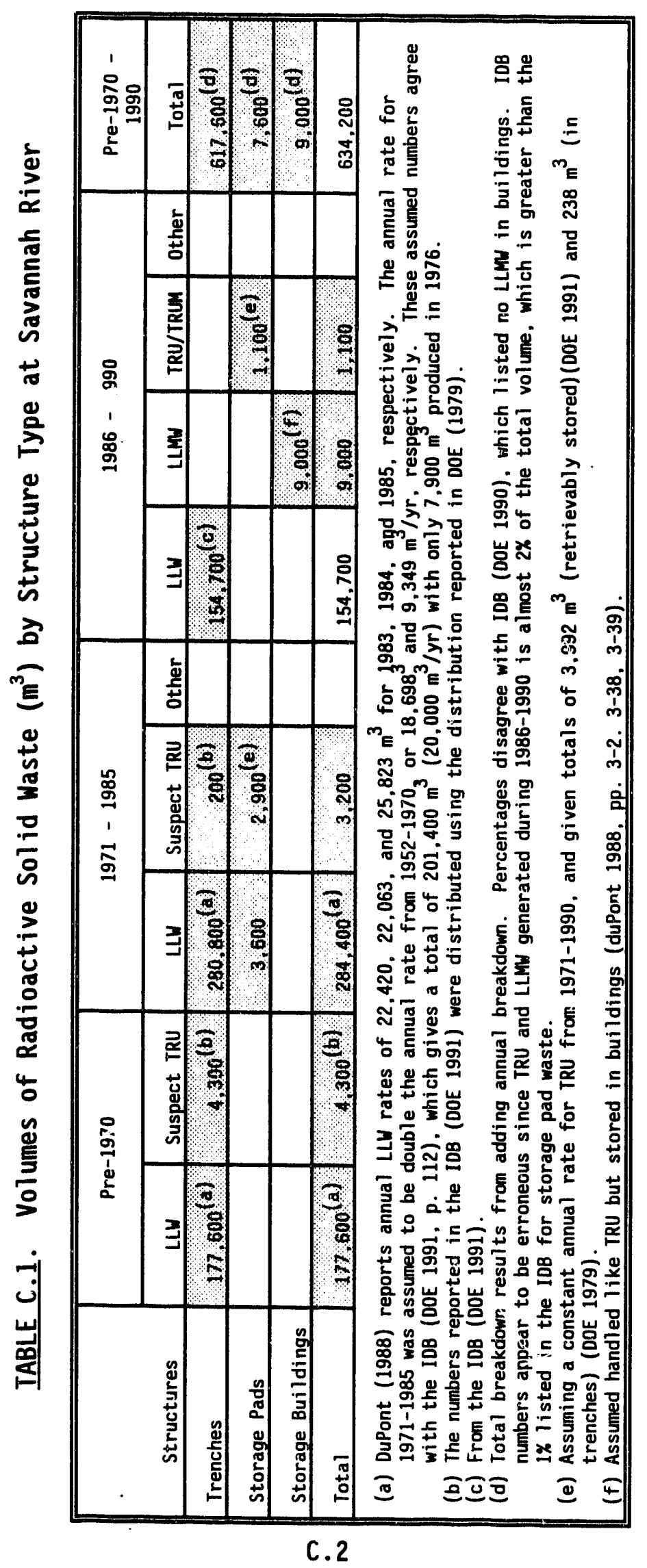




\section{REFERENCES}

DuPont de Nemours and Co. 1988. Safety Analys is - 200 Area, Savannah River Plant, Burial Ground Operations. DPSTSA-200-10 SUPP-8, duPont de Nemours and Co., Aiken, South Carolina.

U.S. Department of Energy (DOE). 1979. Defense TRU Waste - Alternatives for Long-Term Management of Defense Transuranic Waste at the Savannah River Plant. DOE/SR-WM-79-1, DOE Savannah River, Aiken, South Carolina.

U.S. Department of Energy (DOE). 1991. Integrated Data Base for 1991: U.S. Spent Fuel and Radioactive Waste Inventories, Projections, and Characteristics. D0E/RW-0006 Rev. 7, D0E, Washington, D.C. 
APPENDIX D

LOS ALAMOS BURIED WASTE STRUCTURE CHARACTERIZATION DETAILS 
APPENDIX D

\section{LOS ALAMOS BURIED WASTE STRUCTURE CHARACTERIZATION DETAILS}

Provided Structure Categories

\section{Burning Pad}

Contaminated Soil

Flash Pad

Outfall

Pu-contaminated soil

Above-Ground Liquid Impoundments

Absorption Bed

Ditch

Leach Field

Pond

Sand Filter

Sludge Drying Bed

Surface Impoundment

Trench

Trough

Acid Pit

Caissons

Catch Basins

Chlorinator

Contact Chamber

Decontaminatior Holes

Decontamination Pits

Drain Line

Drainfield

Dry Well

Feed Line

Manhole

Seepage, Setting, and Septic Pits

Sewer Line

Sludge Drying Pit

Subsurface Liquid Waste Disposal Unit

Sump

Table D.1 contains an explanation of the methodology used to arrive at the estimated volumes of buried and/or stored waste at Los Alamos.
BWID Structure Categories

Contaminated Soil

Above-Ground Liquid Impoundment

Below-Ground Liquid Impoundment/ Subsurface Disposal Unit

\section{D.1}




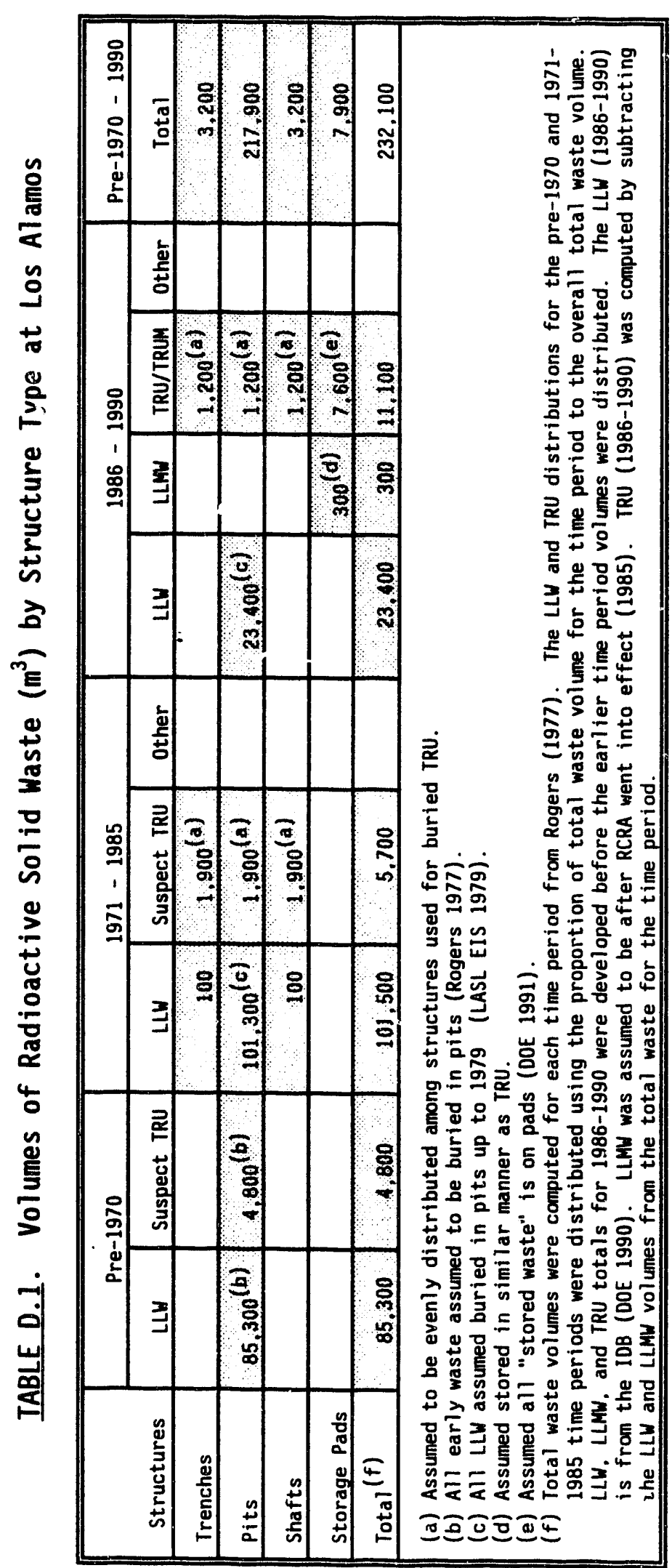

D. 2 


\section{REFERENCES}

Final Environmental Impact Statement for Los Alamos Scientific Laboratory Site. 1979. Los Alamos, New Mexico.

Rogers, M. A. 1977. History and Environmental Setting of LASL Near-Surface Land Disposal Facil ities for Radioactive Waste (Areas $A, B, C, D, E, F, G$, and I): A Source Document. Los Alamos Scientific Laboratory, Los Alamos,

New Mexico.

U.S. Department of Energy (DOE). 1991. Integrated Data Base for 1991: U.S. Spent Fuel and Radioactive Waste Inventories, Projections, and Characteristics. DOE/RW-0006 Rev. 7, D0E, Washington, D.C. 
APPENDIX E

OAK RIDGE BURIED WASTE STRUCTURE CHARACTERIZATION DETAILS 


\section{APPENDIX E}

\section{OAK RIDGE BURIED WASTE STRL'CTURE CHARACTERIZATION DETAILS}

Provided Structure Categories

Unplanned Release

Lagoon

Pond

Retention Basin

Drain Line

Neutralization Unit

Storage Vault
BWID Structure Categories

Contaminated Soil

Above-Ground Liquid Impoundment

Below-Ground Liquid Impoundment/ Subsurface Disposal Unit

Table E.l contains an explanation of the methodology used to arrive at the estimated volumes of buried and/or stored waste at Oak Ridge. 


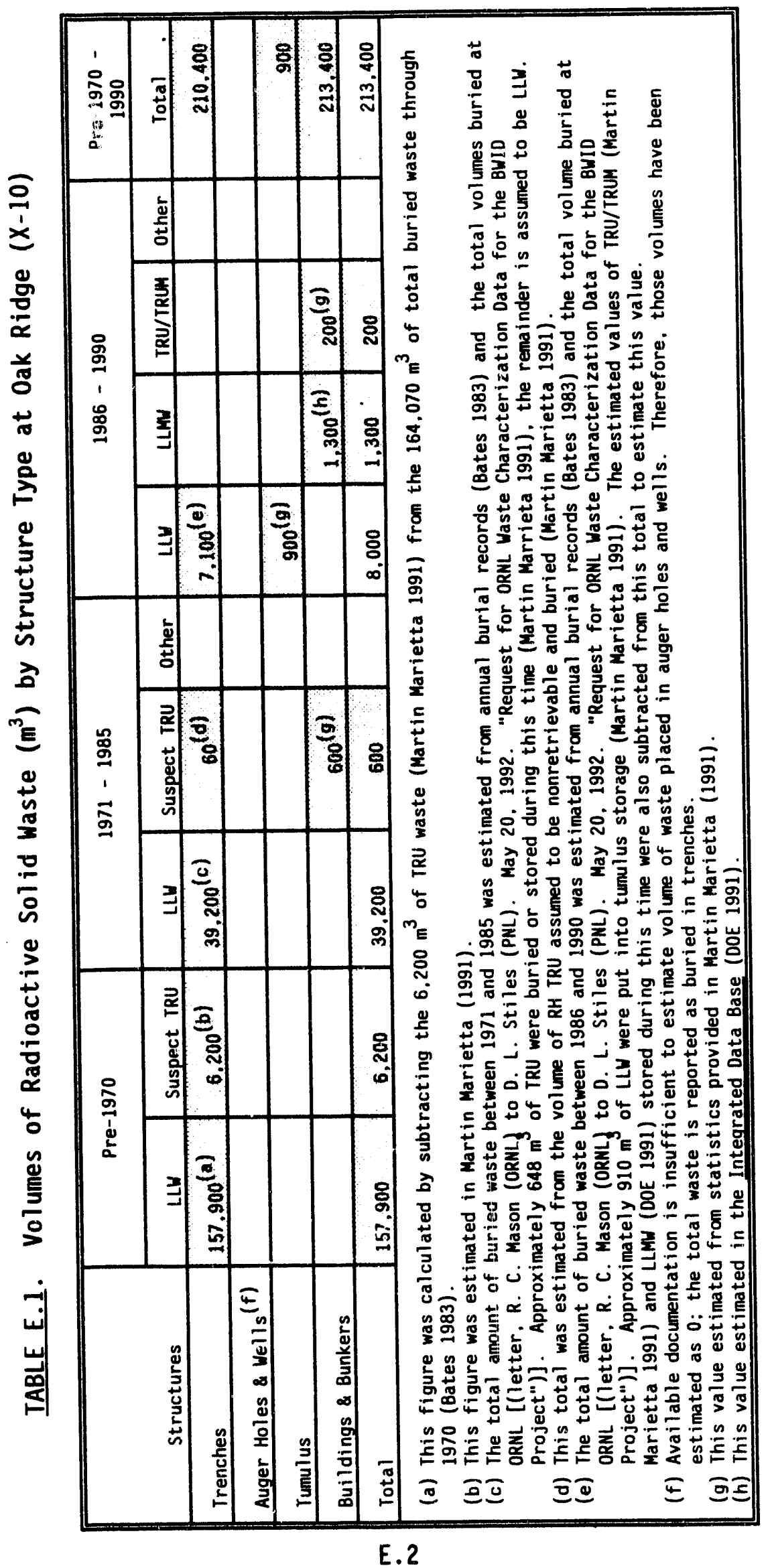




\section{REFERENCES}

Bates, L. D. 1983. Radioactive Solid Waste Storage and Disposal at Oak Ridge National Laboratory, Description and Safety Analysis. ORNL/TM-8201, Union Carbide Corporation, Oak Ridge National Laboratory, Oak Ridge, Tennessee.

Martin Marietta Systems, Inc. 1991. Oak Ridge National Laboratory Waste Management Plan. ORNL/TM-11433/R1, Oak Ridge, Tennessee.

U.S. Department of Energy (DOE). 1991. Integrated Data Base for 1991: U.S. Spent Fuel and Radioactive Waste Inventories, Projections and Characteristics. EOE/RW-0006 Rev. 7, DOE, Washington, D.C. 


\section{APPENDIX $F$}

ROCKY FLATS BURIED WASTE STRUCTURE CHARACTERIZATION DETAILS 


\section{APPENDIX $F$}

\section{ROCKY FLATS BURIED WASTE STRUCTURE CHARACTERIZATION UETAILS}

No contaminated soil structures are currently identified at Rocky Flats.

Table F.I contains the methodology used to arrive at the estimated volumes of waste buried and/or stand at Rocky Flats. 


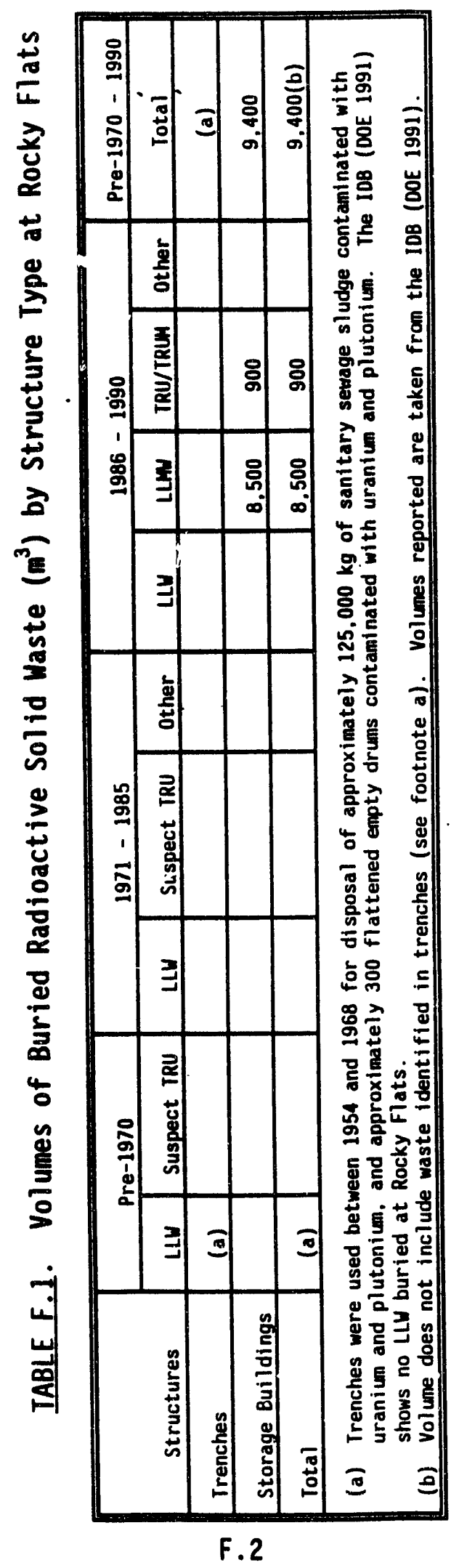




\section{REFERENCES}

U.S. Department of Energy (DOE). 1991. Integrated Data Base for 1991: U.S. Spent Fuel and Radioactive Waste Inventories, Projections, and Characteristics. DOE/RW-0006 Rev. 7, DOE, Washington, D.C. 


\section{APPENDIX G}

OTHER BURIED WASTE STRUCTURE CHARACTERIZATION DETAILS 


\section{OTHER BURIED WASTE STRUCTURE CHARACTERIZATION DETAILS}

Provided Structure Categories

Contaminated Soil

General Surface Soil Contamination

Nuclear Weapons Safety Experiment

Unplanned Release

Waste Pile

Above-Ground Liquid Impoundment

Decontamination Pond

Ditch

Lagoon

Leachfield

Pond

Subsidence Crater

Trench

Below-Ground Liquid Impoundment

Drain Line

Industrial Waste System

Injection Well

Septic System

Subsurface Liquid Waste Disposal Unit

Sump

Waste Handling Area

Wastewater Treatment Unit
BWID Structure Categories

Contaminated SoiT

Above-Ground Liquid Impoundment

Below-Ground Liquid Impoundment/

Subsurface Disposal Unit 


\section{DISTRIBUTION}

No. of

Copies

\section{OFFSITE}

12 DOE/Office of Scientific and Technical Information

11 Idaho National Engineering Laboratory

Idaho Falls, ID 83415

ATTN: K. M. Kostelnik (10)

S. K. Merrill

2 Westinghouse Savannah River Company

Aiken, SC 29808

ATTN: B. D. Helton

J. Stumbaugh

2 Los Alamos National Laboratory

Los Alamos, NM $\mathbf{8 7 5 4 5}$

ATTN: E. Derr

E-Li Chen

2 Oak Ridge National Laboratory

P.0. Box 2n08, B1dg 3047

Oak Ridge, TN 37831-6023

ATTN: D. Daugherty (2)

Toni Moore

Rocky Flats Plant

Golden, CO 80402

\section{ONSITE}

DOE Richland Field Office

D. E. Trader, A5-90
No. of

Copies

15 Westinghouse Hanford Company
M. R. Adams
H4-55
J. D. Berger
LO -18
J. 0. Honeyman
B1 -31
D. M. Johnson
$\mathrm{H} 1-79$
O. L. Kruger
H5-33
A. L. Pajunen
H5-49
J. G. Riddelle
$\mathrm{HI}-79$
R. J. Roberts
J. C. Womack
Environmental
N3-13
LO-18
Data Management
Center (6)
H4-22

38 Pacific Northwest Laboratory

L. L. Armacost

K6-61

S. Q. Bennett

K7 -90

C. M. Blackburn

$\mathrm{K} 6-61$

J. A. Dirks

$\mathrm{K} 6-61$

L. L. Fassbender

$\mathrm{K} 6-61$

S. M. Garrett

G. M. Holter (2)

K6-61

P. S. Kaae (10)

K7-97

J. F. Keller

K6-61

D. K. Kreid

L6-13

G. W. McNair

$\mathrm{K} 1-22$

M. S. Peffers

K $7-90$

M. E. Peterson

K7-97

W. A. Ross

P7-41

J. L. Scott

P7 -41

D. A. Seaver

S. M. Short

B. L. Smith (2)

P7-39

K6-61

K7-94

D. C. Stapp

KE- 40

K7-97

D. L. Stiles

K6-61

R. C. Walling

K7-97

Publishing Coordination Technical Report Files 


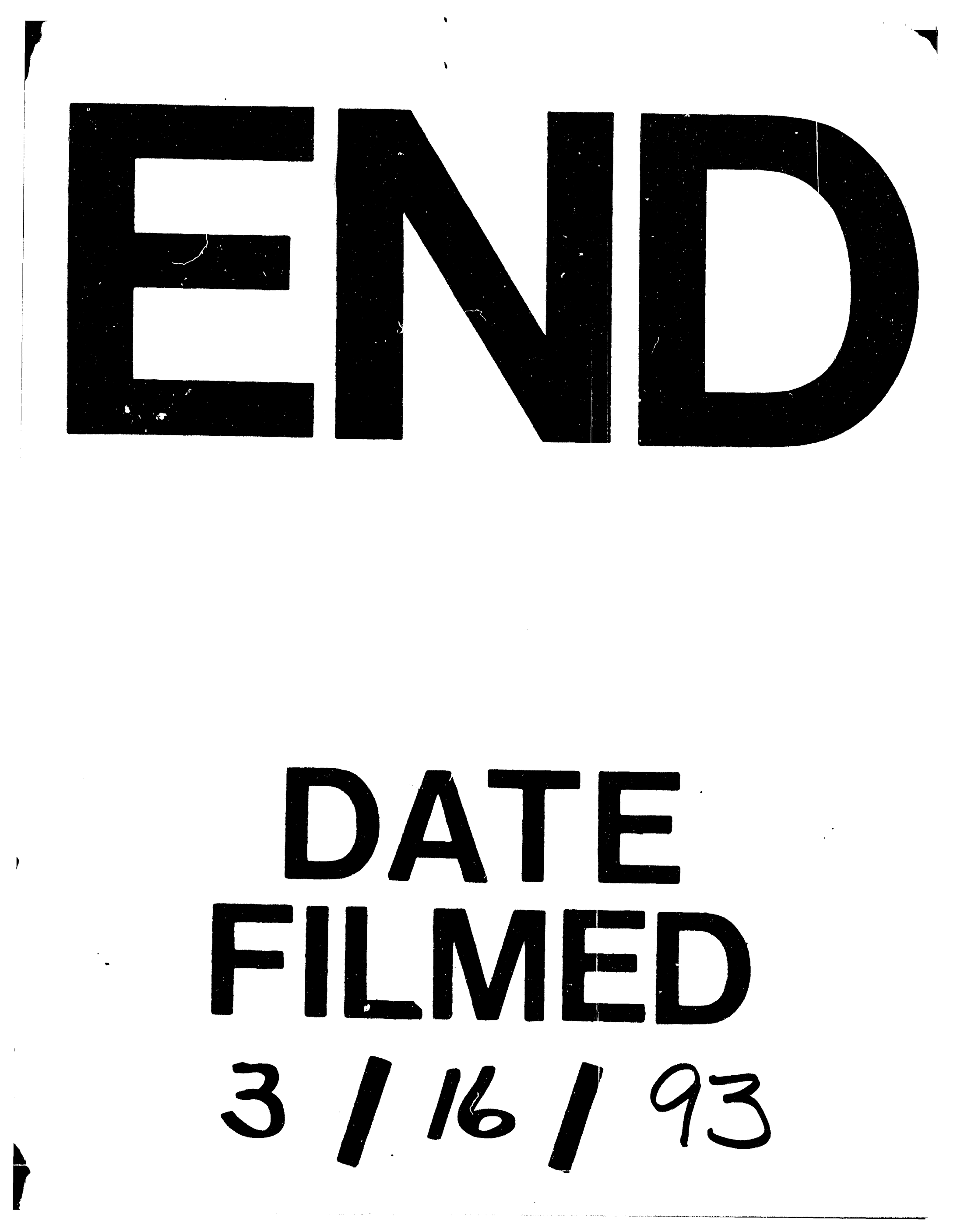




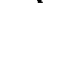

